\title{
ASSESSING BUDGETARY MANAGEMENT OF LOCAL GOVERNMENT IN ACEH, INDONESIA
}

\author{
BY \\ INTAN FARHANA \\ A thesis \\ submitted to Victoria University of Wellington \\ in partial fulfilment of the requirements for the degree of \\ Master of Commerce
}

Victoria University of Wellington

2019 



\begin{abstract}
This interpretive case-based study explores issues of budgetary management in Aceh provincial government. Until 2018, Aceh showed significant problems in its budget cycle with the budget being approved late every year except 2014. Thus, this study aims to investigate the reasons for these delays, along with their impacts on budget execution. Further, as Aceh is a predominantly Muslim society with Islamic values and principles fundamental to its culture and identity, this study also explores whether Islamic teachings are well-embedded in its government budgeting. To investigate these issues, I gathered written materials related to the budgeting process and conducted 19 interviews with local government officials, politicians, Muslim scholars, and a corruption watchdog, analysing these through three linked accountability frameworks: considering accountability through relationship, responsibility, and answerability dimensions, Boltanski and Thévenot's (1999) Sociology of Worth (SoW) framework, and Islamic accountability.

I found the key reasons for the budget delays were miscommunications and heated debates in budget discussions between Aceh's legislature and executive government resulting from conflicts of interest and priorities. The budget delays negatively affected budget execution, which, since Aceh's economy depends heavily on government spending, reduced economic activity and so the social welfare of its people. Given the problems in its budgetary management, including budget delays, conflicting interests, and lack of transparency, the implementation of Islamic principles and values in Aceh's government budgeting remains unsatisfactory.

This study offers several contributions to the literature and practice: (i) it generates new ideas for the classification of SoW's orders of worth when applied to public budgeting and accountability in a devout Muslim society; (ii) it outlines some challenges in implementing Islamic principles and values into government budgeting; and (iii) it notes some potential improvements for Aceh provincial government to achieve better budgetary management and accountability.
\end{abstract}





\section{ACKNOWLEDGEMENTS}

First and foremost, I praise Allah, the Almighty, for His blessings and strengths, for enabling me to complete my Master's study at Victoria University of Wellington (VUW).

I wish to convey my sincerest appreciation and gratitude to my supervisor, Dr Clare Markham. Her endless support, encouragement, patience, and supervision was indispensable throughout my journey in writing this thesis. Further, her constructive feedback contributed significantly to the success of this study and has given me invaluable knowledge in conducting research.

Special thanks also to my programme director, Dr Christopher Cripps, for his invaluable support and aid throughout my studies. I also would like to extend my appreciation to my SACL lecturers, Prof Judy Brown; Prof Ian Eggleton; A/Prof Carolyn Fowler; Dr Ken Bates (rest in peace); Dr Rodney Dormer; Dr Jonathan Barrett; Dr Amanda Reilly; Dr Sendirella George; and Dr Thu Phuong Truong. Through them, I learned so much about accounting, research, critical thinking, and gained acquired life-long experience! Their contributions were essential to the completion of this thesis.

I also thank the lovely participants interviewed for this research and those who helped me during fieldwork. Without their commitment, help, and input, this study would not have been possible.

I would also like to acknowledge Julian Vesty from the University of Canterbury who provided copy-editing and proofreading services in accordance with the Editorial Advice Policy of VUW.

I owe a great debt of appreciation to the Indonesian government for the scholarship and research funding granted to me through the Indonesian Endowment Fund for Education (LPDP). Without their sponsorship, my dream to pursue a Master's degree at VUW would have remained only that. Insha Allah, I will do my best to contribute to Indonesia in a meaningful manner. 
Throughout my time in Wellington, my beloved friends are the people whom I treasured the most. To all of my friends from the Indonesian Student Association (PPI), the Indonesian community in Wellington, MCom programme, and to my beloved flatmates...your presence in this journey has added so much happiness and positivity in my life. Thank you!

Last but not least, my deepest gratitude goes to my parents, Hasan Basri and Qunuti Abdullah. Their constant support, love, and patience have given me the strength to keep believing in myself. Thank you so much Ayah and Mama for listening to my woes and annoying ramblings, for loving me so much, and for truly believing that I can achieve whatever I wish to and for constantly sending prayers for me. 


\section{Table of Contents}

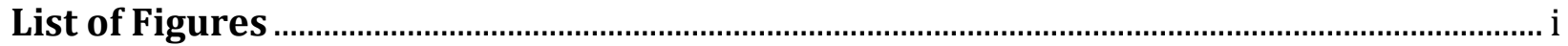

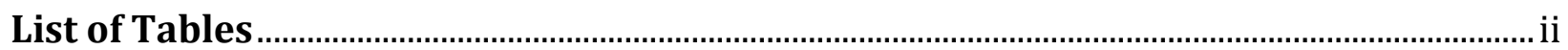

List of Abbreviations Used.........................................................................................................

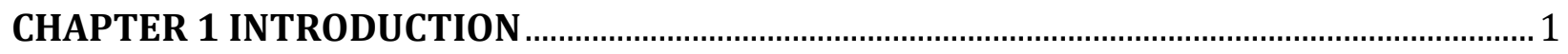

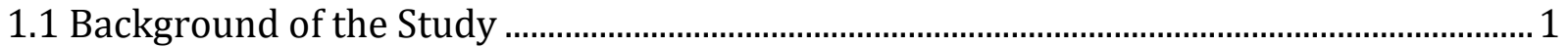

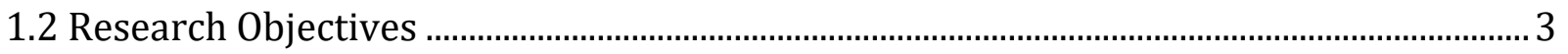

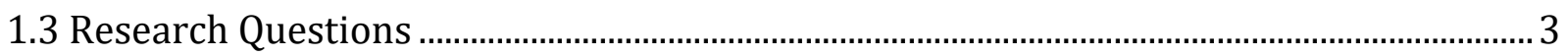

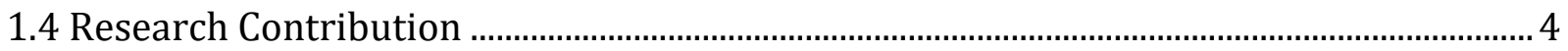

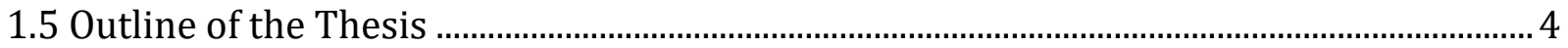

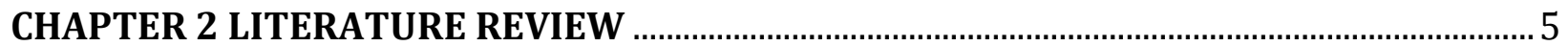

2.1 Budgetary Management in Public Sector ............................................................................... 5

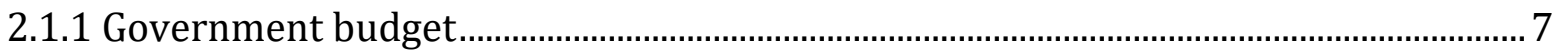

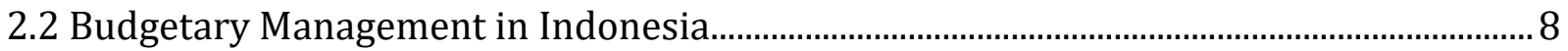

2.3 Budgetary Management in Aceh............................................................................................. 14

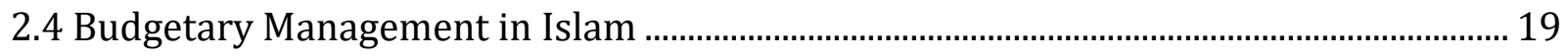

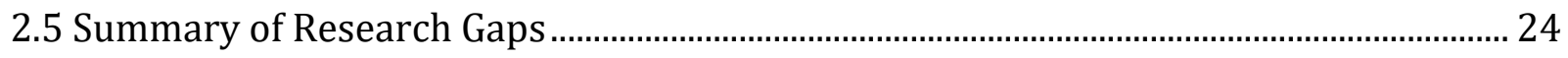

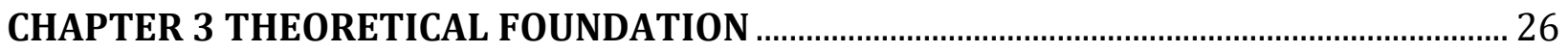

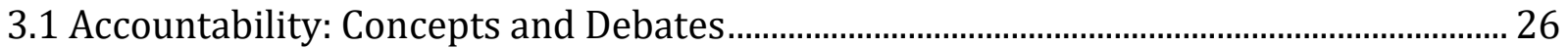

3.2 Accountability in the Public Sector: A Sociology of Worth Framework for Analysing

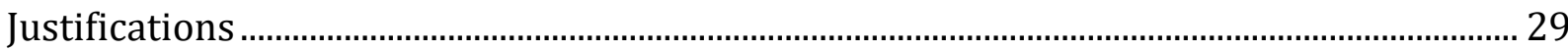

3.3 Situating the Theoretical Framework in Aceh's case .......................................................... 32

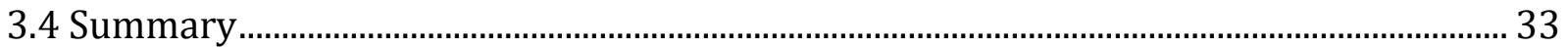

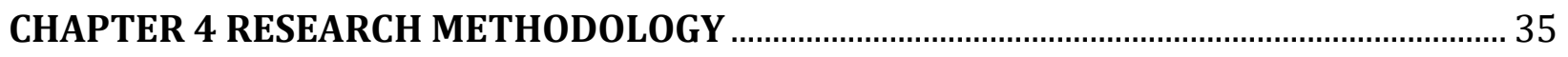

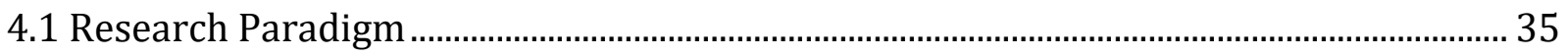

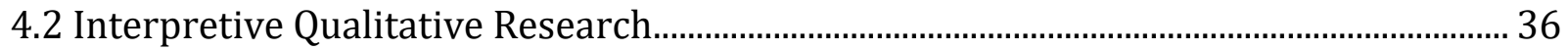

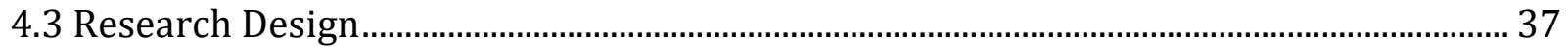

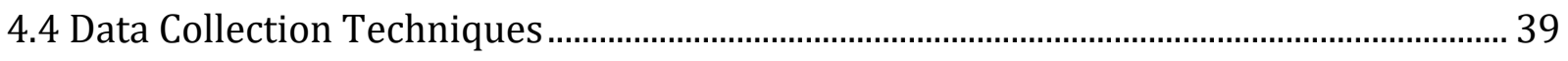

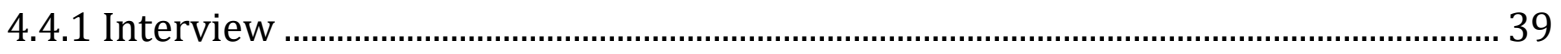

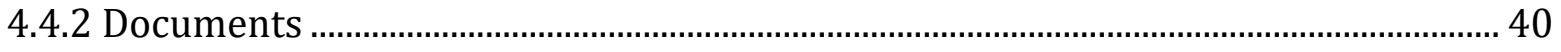

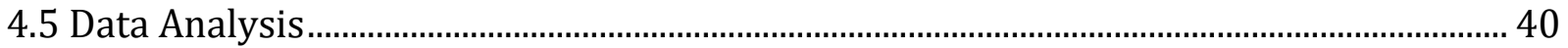

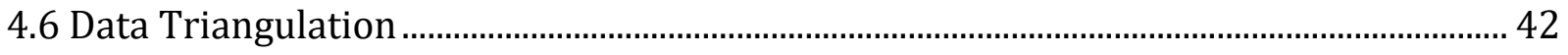


4.7 Research Ethics and Data Confidentiality ................................................................................. 43

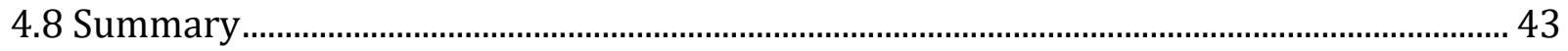

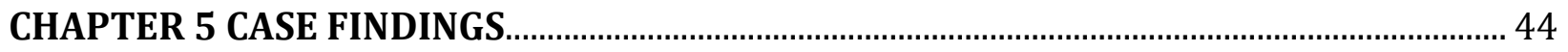

5.1 Late Budget Approval in Aceh: Why Did It Happen? …………………………………….. 44

5.1.1 Political interaction between Aceh's executives and DPRA........................................ 45

5.1.2 The Aspiration Fund................................................................................................... 50

5.2 Late Budget Approval in Aceh: What are the Impacts on Budget Execution? ................ 54

5.3 As a Province Implementing Shari'a, Does Aceh's Budgetary Management Reflect Islamic Teachings? .................................................................................................................... 58

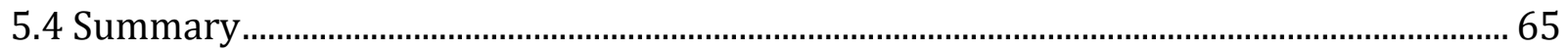

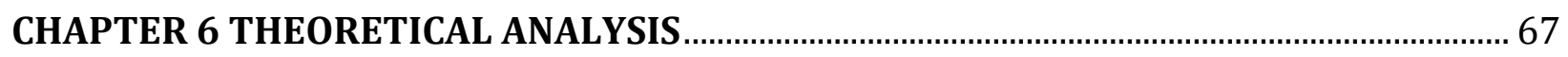

6.1 Who Is/Are to Blame for Late Budget Approval in Aceh? A Sociology of Worth Analysis................................................................................................................................. 67

6.1.1 Aceh's budget approval: an art of compromising …………………………………... 73

6.2 Summary ......................................................................................................................... 77

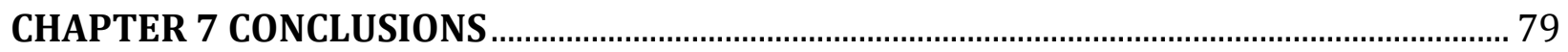

7.1 Summary of Key Findings ................................................................................................ 79

7.2 Research Contributions ....................................................................................................... 83

7.3 Limitations of the Research.................................................................................................. 85

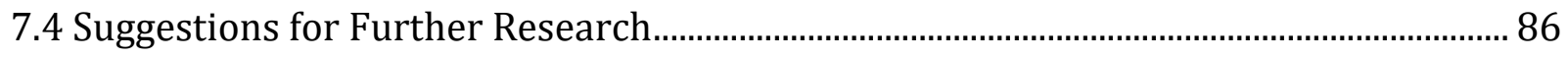

7.5 Autobiographical Reflection ............................................................................................ 86

REFERENCES

APPENDIX A List of Arabic and Islamic Words Used ............................................................ 99

APPENDIX B Linkage between Research Questions and Interview Questions.............100

APPENDIX C List of People Interviewed ..............................................................................105

APPENDIX D List of NVivo Nodes and Major Themes Generated ......................................106

APPENDIX E Participants' Information Sheet and Consent Form ......................................108 


\section{List of Figures}

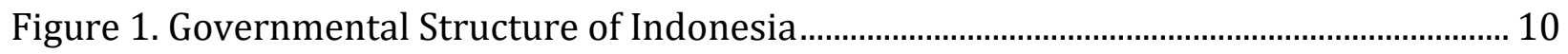

Figure 2. Relationships Formed in the Local Budgeting Process ................................................ 12

Figure 3. Aceh's Budget Process - Mandated Timeline vs. 2018 Timeline................................ 18

Figure 4. Islamic Model of Good Governance..................................................................................... 21

Figure 5. Classical Hierarchical and Networked Model of Organisations ................................. 32

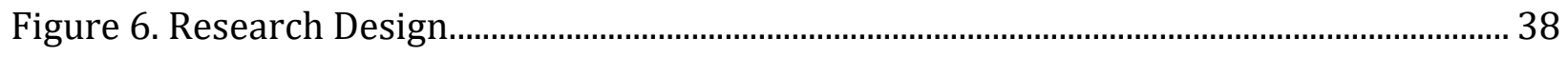

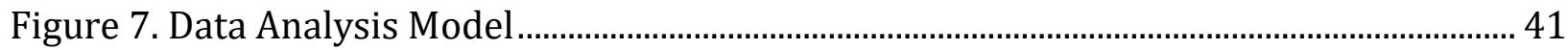

Figure 8. Consequences of Late Budget Approval in Aceh Province............................................ 57 


\section{List of Tables}

Table 1. Date of Budget Approval for Aceh’s Provincial Government....................................... 17

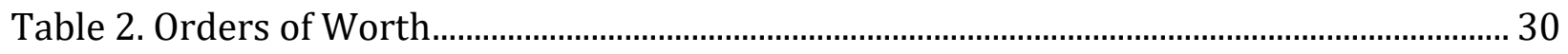

Table 3. Date of KUA-PPAS Submission and Discussion ................................................................ 48

Table 4. Budget Realisation of Aceh Local Government for Fiscal Year 2013 to 2018.......... 55

Table 5. Summary of Arguments by Executives and DPRA ........................................................ 68 


\section{List of Abbreviations Used}

\begin{tabular}{|c|c|}
\hline APBA & Aceh's Provincial Budget \\
\hline $\mathrm{AF}$ & Aspiration Fund \\
\hline $\mathrm{B} \& \mathrm{~T}$ & Boltanski \& Thévenot \\
\hline BAPPEDA & Aceh Development Planning Agency \\
\hline BPKA & Financial and Property Management Agency \\
\hline DAK & Specific Allocation Grant \\
\hline DAU & General Allocation Grant \\
\hline DOKA & Aceh's Special Autonomy Fund \\
\hline DPRA & Aceh Provincial Parliament \\
\hline DPR RI & Indonesia National Parliament \\
\hline GAM & Free Aceh Movement \\
\hline KUA-PPAS & General Budget Policies - Provisional Budget Priorities and Funding Levels \\
\hline MoU & Memorandum of Understanding \\
\hline MP & Member of Aceh Provincial Parliament \\
\hline Musrenbang & Development and Planning Meeting \\
\hline RAPBA & Aceh's Budget Draft \\
\hline RKA & Agency Budget and Work Plans \\
\hline RKPA & Aceh government-wide work plan \\
\hline RPJM & Medium-term Development Planning \\
\hline RPJP & Long-term Development Plan \\
\hline SoW & Sociology of Worth \\
\hline TAPA & Aceh's Executive Budget Team \\
\hline
\end{tabular}





\section{CHAPTER 1 INTRODUCTION}

This chapter describes the background and objectives of my study. It begins with a brief discussion of some problems in budgetary management in Indonesia's local government, particularly in the province of Aceh, the main focus of investigation. The chapter then continues to present the study's objectives, research questions and expected contributions, before outlining the remainder of the thesis.

\subsection{Background of the Study}

Since the emergence of the concept of good public governance, both developed and developing countries are moving toward public sector reforms (Parthasarathy, 2005; Jurnali \& Siti-Nabiha, 2015). These reforms drive governments to shift focus in their budgetary governance from outputs to outcomes to ensure an effective, efficient, and equitable delivery of public goods and services (Kristensen, Groszyk, \& Bühler, 2002; Bovens, 2007; Denhardt \& Denhardt, 2015; OECD, 2015). Furthermore, through good public governance, governments aim to create sustainable development by promoting participation, efficiency, fairness, and governmental accountability (Kemp, Parto, \& Gibson, 2005; Grindle, 2012). Consequently, governments must focus on how to manage finite resources responsibly and accountably to deliver goods and services effectively and efficiently to meet the infinite needs of the people.

In Indonesia, such reforms began after the 1998 collapse of Soeharto's regime, ending a "centralistic and authoritarian government and management" (Kaidonis \& Moerman, 2003). The reforms have brought a new era for the republic where regional autonomy is empowered through decentralisation and deconcentration. According to Jurnali and SitiNabiha (2015), Indonesia has instituted performance measurement, bureaucratic reform, and good public governance practices, especially at the local level. However, the results remain arguably unsatisfactory, with many local governments still lacking integration between planning and budgeting, showing deficiencies in the financial reporting system and possessing low capability to manage financial resources effectively and efficiently (Jurnali \& Siti-Nabiha, 2015; Basri \& Nabiha, 2016; Sofyani, Akbar, \& Ferrer, 2018). 
This study assesses the budgetary management of one of Indonesia's local governments, Aceh provincial government. Aceh was chosen as the study setting because it is one of only five provinces in Indonesia with special autonomy, ${ }^{1}$ making it financially rich yet still experiencing budgetary management problems. Aceh has a long history of struggle against central rule, with a 29-year conflict between the Free Aceh Movement (GAM) and the central government ending in 2005 through the signing of a peace agreement in Helsinki and resulting in greater power and financial resources for the province. However, significant problems in financial planning and resource allocation remain and the budget cycle in Aceh has not been managed in accordance with the mandated timeframe since at least 2005 (World Bank, 2006; Aspinall, Hillman, McCawley, \& ANU Enterprise Pty Ltd Staff, 2012; Tempo.co, 2013; Basri \& Nabiha, 2016; BPKA Aceh Province, 2019). In 2008, for example, the budget legislation was delayed by six months, not passing until June 2008 (BPKA Aceh Province, 2019). Subsequent annual budgets have been legalised late each year, except in 2014 and 2019. In 2018, the Aceh Provincial Parliament (DPRA) did not agree to the proposed budget, resulting in the Governor of Aceh issuing a decree in March 2018, three months later than required, to implement the preceding year's budget for 2018 (Serambinews.com, 2018b; BPKA Aceh Province, 2019). Other than budget delays, there have also been issues such as the mismanagement of public funds.

The mismanagement of public funds and poor resource allocation in Aceh have been extensively criticised by corruption watchdogs and scholars. For example, GeRAK, a local corruption watchdog, argues that there are indications of collusion between Aceh's executive government and the members of DPRA (MPs) in managing the budget $^{2}$ (GeRAK, 2017). Others emphasise that there are "a range of institutional problems, delays in the legislation and utilisation of budget (sic), and excessive political interest, as well as bureaucratic controls" (Aspinall et al., 2012, p. 52). These problems have had a substantial impact on

\footnotetext{
1 The central government of Indonesia grants special autonomy status to five provinces; DKI Jakarta, DI Yogyakarta, Aceh, Papua, and West Papua. Aceh province received this status in 2001 (Republic of Indonesia, 2001a).

${ }^{2}$ GeRak has particularly criticised a large amount of money allocated for dana aspirasi (AF), which in their view is particularly vulnerable to misuse or corruption (GeRAK, 2017) since its allocation is not controlled by any Act. Instead, the Indonesian Parliament argues that it relates to strengthening the relationship between members of Parliament and society (constituents) (Act No.17/2014 People's Consultative Assembly, Legislative Council, House of Representatives, and Regional House of Representatives).
} 
Aceh's economic and social well-being: in 2018, Aceh's economic growth was only 4.18\%, well below the national level of $5.17 \%$ and its poverty and unemployment rates stood at $15.92 \%$ and $6.55 \%$ respectively, higher than the national rates of 9.66 and $5.34 \%$ (Badan Pusat Statistik Aceh, 2018c, 2018d, 2018b). These data indicate that despite Aceh's increase in financial resources after Act No.18/2001 Special Autonomy for Aceh Province was passed in 2001 and the peace agreement signed in 2005, the Acehnese quality of life has not improved proportionately. Thus, I investigate whether these problems relate to the issue of significant budget delays in Aceh provincial government.

Aceh is well-known as the Veranda of Mecca, with $98 \%$ of the population being Muslim (Badan Pusat Statistik Aceh, 2010). Islamic values and perspectives are central to Acehnese identity and culture. In 2001 the province received the right to implement Shari'a, or Islamic law (Republic of Indonesia, 2001a) which was enacted in 2006 after the peace agreement. Despite this, there has been little discussion in Aceh about basing the management of public funds on Islamic values and principles. This is surprising, given the importance placed by Islamic teachings on applying Islamic values and principles in all aspects of life, including public wealth management (Possumah \& Ismail, 2012). Therefore, this study also explores budgetary management in Aceh from an Islamic perspective. This leads to my research objectives for this study, which are as follows:

\subsection{Research Objectives}

1. To investigate the issue of poor budget cycle in Aceh local government and its impacts on budget execution.

2. To investigate the influence of Islamic teachings in Aceh's budgetary management. These objectives are investigated in this study through the following research questions:

\subsection{Research Questions}

RQ1: What are the reasons behind the late budget approval in Aceh? RQ2: What are the impacts, if any, of late budget approval to the budget execution? RQ3: Does the budgetary management in Aceh local government represent a good implementation of Islamic principles and values?

a. If yes, how so?

b. If not, why not? 


\subsection{Research Contribution}

This research aims to provide new insights into the budgetary management systems of local government in Indonesia. The study will benefit future decision-making in local government budgeting. Furthermore, considering budgetary management in Aceh with an Islamic perspective will also enrich the current academic literature in both governmental accounting and Islamic accounting.

\subsection{Outline of the Thesis}

This thesis has seven chapters, including this introduction chapter. The remaining six chapters are organised as follows:

Chapter Two reviews relevant literature, first explaining concepts of budgetary management in the public sector, followed by budgetary management in Indonesia and Aceh province and then Islamic perspectives on good governance and public budgeting.

Chapter Three discusses the theoretical foundation of this study, exploring accountability theory in the public sector context along with Sociology of Worth (SoW) framework of Boltanski and Thévenot or B\&T (1999).

Chapter Four explains the research methodology employed in this study. It presents a discussion of research paradigm, qualitative research and the justifications for using an exploratory case study with an interpretive data analysis. Subsequently, the research design, techniques for data collection and data analysis are also explained.

Chapter Five presents the empirical findings of the study. It starts with reasons for late budget approval in Aceh and its impacts. A discussion of the implementation of Islamic values and principles in Aceh's budgetary management closes this chapter.

Chapter Six analyses of the research findings theoretically. The chapter discusses my analysis of the findings presented in Chapter Five through the Sociology of Worth (SoW) framework, examining the justifications of interviewees.

Chapter Seven closes the thesis by summarising key findings before moving to the theoretical and practical contributions of the study and offering recommendations for addressing Aceh's budgeting issues. Finally, I explain the study's limitations and offer brief suggestions for future research. 


\section{CHAPTER 2 LITERATURE REVIEW}

This chapter reviews relevant literature, to gain an understanding of the investigated phenomenon - budgetary management in Aceh. This chapter begins by exploring budgetary management in the public sector, followed by a review of the literature concerning budgetary management in Indonesia and Aceh. The concept of budgetary management in Islam is also explored before ending with a summary of research gaps.

\subsection{Budgetary Management in Public Sector}

Government has been defined as the system in which a state or community is governed (Oxford University Press, 2018). Generally, a government aims to maximise the welfare of its citizens (Jordaan \& Fourie, 2007), although, due to various historical, cultural and political forces, extended functions of government can be established according to each country's constitutions or law (OECD, 2015). In Indonesia, for example, the 1945 Constitution preamble states that:

[The] government of the state of Indonesia which shall protect all the people of Indonesia and all the independence and the land that has been struggled for, and to improve public welfare, to educate the life of the people and to participate toward the establishment of a world order based on freedom, perpetual peace and social justice.

Today, in an era concerned with good public governance, the role of the government has been transformed to creating sustainable development (Batley \& Larbi, 2004; Kemp et al., 2005; Jurnali \& Siti-Nabiha, 2015). This, of course, does not neglect or replace its main purpose of providing public goods and services. In sustainable development, governments attempt to combine environmental issues with socio-economic issues aiming to create a better and more just world (Hopwood, Mellor, \& O'Brien, 2005; Kemp et al., 2005). This means that the government, including public sector managers, is focused on developing sustainably through effectiveness, efficiency, and accountability (Kemp et al., 2005), specifically in the resource allocation process by encouraging public participation and 
transparency. In so doing, the resource allocation or budgeting processes can work towards its main purpose of maximising public welfare according to people's needs.

Another transformation in the functions of government due to the advent of good governance is concerned with public value. According to Moore (1994), a public sector manager's task is to create public value, which he or she sees as existing in the relationship between operational capabilities and legitimacy and support, although the precise definition of public value is disputed ${ }^{3}$ (Alford \& O'Flynn, 2009). Generally, public value relates to "the value created by the government through services, laws regulation, and other actions" (Kelly, Mulgan, \& Muers, 2002, p. 4). How this value is defined depends on people's preferences as it is relative to circumstances and social environment (Moore, 1994; Kelly et al., 2002; Alford \& O'Flynn, 2009). For example, a government programme deployed successfully in one province might not be beneficial if implemented in another province due to the province's differing political, social, or economic environment. Therefore, to create public value, it is important for the government to understand the context and setting of their policies.

Creating public value relates to the terms 'public interest' and 'public benefits' which have been used interchangeably as justifications for policies made by politicians and bureaucrats (Alford \& O'Flynn, 2009). However, Moore (1994) proposes in his framework a concept of public value as an evaluation framework to analyse and diagnose the value that is currently being produced by government (Alford \& O'Flynn, 2009). In the case of budgetary management, this can be beneficial in evaluating the efficiency and effectiveness of current resource allocation in maximising public welfare. However, greater depth on the concept of public value and how government approaches or should approach public value are beyond the scope of this study as it is limited to the investigation of budget delays in Aceh. Nevertheless, the concept offers a useful stress on the importance of governments improving economic and social well-being through allocating financial resources effectively and efficiently. In the following section, therefore, I discuss the government budget, an important government policy document, and its links with accountability.

\footnotetext{
${ }^{3}$ Alford and O'Flynn (2009) note that some scholars regard public value as more than Moore's three elements, but argue that much of the criticism of Moore's work results from misunderstandings of his approach.
} 


\subsubsection{Government budget}

The government budget plays a crucial role in managing public resources and is considered the primary fiscal policy instrument of government institutions, showing the annual plans of a government in implementing their policies (Hackbart \& Ramsey, 1994; Goddard, 2004). In the public sector, a budget serves three general functions (Veiga, Kurian, \& Ardakanian, 2015, pp. 26-27):

1. Economic

[A]n exercise of planning, controlling, and administering activities, intended to balance revenues and expenditures and to allocate available resources efficiently in order to maximise social welfare.

2. Political

[B]udget proposals offered by the executive body of subnational governments have to be approved by committees that are usually elected.

3. Legal

[B]udgets are regulated by laws, rules and regulations and, in some cases, they have a legal status [...] They establish limits to managerial decisions and actions of subnational governments, and officials violating them may be subject to penalties.

These functions show the difference between budget mechanisms in the public sector and the private sector, as political and public legitimation pressures are involved in the public sector budget process (Peters, 2001) that are either absent or less important in the private sector. As Farhan (2018, p. 12) notes, "budgets are not technocratic products; they are the result of complex negotiations among budget players". This means the governmental budget process involves political power, as there are multiple political relationships engaged with different interests, indicating the complexity of public sector relationships and leading to deeper complexity in its accountability.

Many studies have been undertaken on budgeting in the public sector (see e.g. Kluvers, 2001; Ebdon, 2002; Goddard, 2004; Venning, 2009; Amujiri, 2012; Farhan, 2018), with most of these noting that budgeting is essential to enhancing public sector accountability. Ebdon 
(2002) in her work on participatory budgeting argues that citizen participation in budgeting can improve citizens' trust in government, in line with Goddard's (2004) concept of public accountability which emphasises the relationship between public officials and society. Thus, to gain public trust, it is crucial for the government to pay greater attention not only to the amounts of resources allocated, but also to the budget process, ensuring its accountability. The budget cycle, for example, is a preeminent accounting practice in achieving good accountability (Goddard, 2004) because it represents the annual plans of government. Any delay in the adoption of the annual budget can result in delays to government projects and planning. Therefore, while some studies argue that budgets can enhance accountability (see Kluvers, 2001; Venning, 2009; Almqvist, Grossi, van Helden, \& Reichard, 2013), having good accountability can also improve the budgetary management (Farhan, 2018).

Next, as this study focuses on budgetary management at a local level in Indonesia, I move to discussing Indonesia's budgetary management to provide some insights to the budgeting context in Indonesia and in Aceh.

\subsection{Budgetary Management in Indonesia}

Indonesia is considered the world's largest island country, with more than 17,000 islands, 34 provinces (consisting of 511 municipalities and regencies) 4 and a population of approximately 261 million people in 2017 (Badan Pusat Statistik, 2018). It has a presidential system in which the President and Vice President are directly elected by the people and serve as head and deputy head of state and government respectively. As the head of government, the President holds the power of financial state management, but Act No.17/2003 State Finances stipulates that he or she delegates this power to the Minister of Finance, who acts as the government fiscal manager and representative.

Since the 1998 public sector reforms, the Indonesian Parliament has played a stronger role in controlling and monitoring government policy and programmes (Blöndal, Hawkesworth, \& Choi, 2009; Emirullah, 2013). In 1999, Indonesia's public sector underwent through a substantial decentralising transformation after Act No.22/1999 Local Government was passed, transferring an unprecedented degree of political power to the provinces. The

\footnotetext{
${ }^{4}$ Other than name, there are no substantial differences in duties and responsibilities between municipality and regency (Thahar, 2016).
} 
regional autonomy in Indonesia stands under decentralisation and deconcentration. The Act describes decentralisation as the delegation of power from central to local government in managing its affairs, including the local budgeting process in which the local government (provincial or municipal) is allowed to allocate its resources based on local priorities. Meanwhile, deconcentration refers to the transfers of administrative authority from the central government to the governor, head of regents, municipalities and vertical agencies. ${ }^{5}$ This aims to increase efficiency and effectiveness of the administrative process, ensuring synchronisation on regulations and policies between central and local governments. Further, under Act No. 23/2014 Local Government, decentralisation also meant that provincial, municipal, or regency offices and agencies were no longer obligated to report to central ministries, only to their respective provincial, municipal, or regency legislature, with the exception of vertical agencies. The delegation of power and accountability processes in Indonesia governmental structure is illustrated in Figure 1 (see overleaf), showing that authority is delegated downwards, whilst accountability is achieved by reporting upwards, with the local executive required to present a performance report to the local legislature once a year.

\footnotetext{
${ }^{5}$ Vertical agencies refer to central government agencies situated in the provinces, such as the Indonesian National Police.
} 


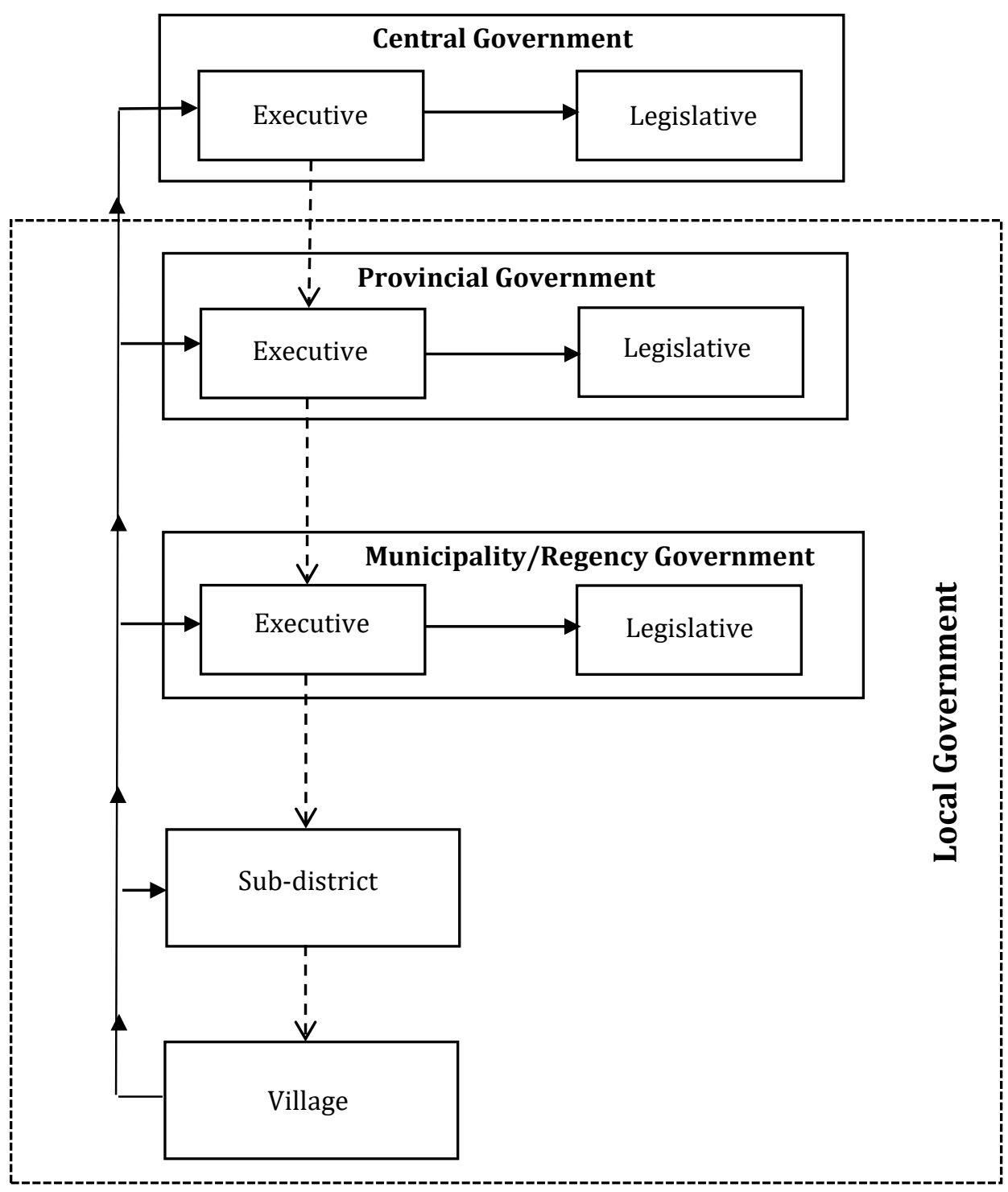

$---\rightarrow$ Authority delegation

$\longrightarrow$ Report on performance

Figure 1. Governmental Structure of Indonesia (adapted from Basri and Nabiha (2016) and Thahar (2016))

The mandated budget cycle in Indonesia takes around a year, from 1 January until 31 December with the fiscal year starting on 1 January (Republic of Indonesia, 2003). The local resource allocation and budgeting processes are bottom-up, begining with a Musrenbang (Development Planning Meeting) at sub-district level. Musrenbang is an open forum 
attended by people and representatives of government, including officials from executive government (executives) and MPs. The whole process of local budgeting is led by top executives - the governor for provinces and the head of municipality or regency for districts - although they must submit their proposed budgets to the relevant parliament for approval. In the event that a parliament does not approve the proposed budget, the executive government should instead implement a repeat of the prior year's state budget (1945 Constitution, 1945). It is important to note that although the local government allocates their financial resources based on regional priorities, they must also adhere to the central government's guidance on local budgeting (i.e. the Ministry of Home Affairs regulation) issued each year. I illustrate the relationships formed in the budgeting process at local level in Figure 2 (see overleaf). There are three main layers of relationships in play: between public or society leaders and the local legislative; between public or society leaders and the executive; and between the local legislative and the local executive. Thus, the local legislative is held accountable to the public because they are directly elected and the local executive is accountable both to local legislative and public. 


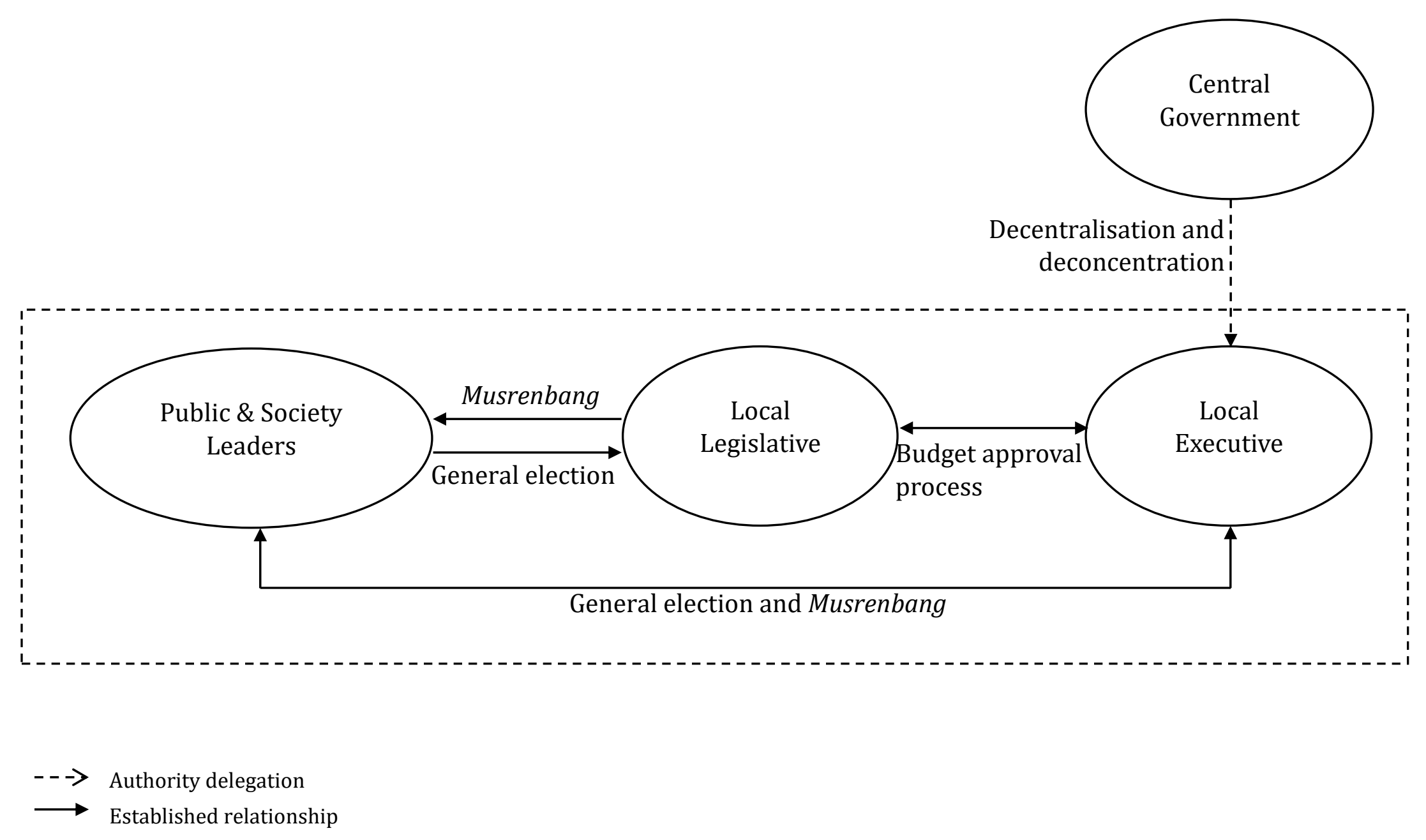

Figure 2. Relationships Formed in the Local Budgeting Process 
In Indonesia, local governments depend heavily on central government transfers for financial resources. Local revenue and taxes generate only a small proportion of funding (Dixon \& Hakim, 2015), with central government providing the majority of money through revenue-sharing, ${ }^{6}$ general allocation grants (DAU), ${ }^{7}$ specific allocation grants (DAK), ${ }^{8}$ and the special autonomy fund ${ }^{9}$ (Republic of Indonesia, 2005; World Bank, 2006). Act No. 32/2004 Local Government and Act No. 33/2004 Fiscal Balance between Central Government and Local Governments stipulate that fiscal decentralisation in Indonesia's public sector reform is intended to drive the local budgeting process and outcomes to be effective and efficient in addressing social and economic problems at a local level. Despite the greater flexibility given to local governments in allocating and managing financial resources, the central government still imposes some numerical limits, termed mandatory spending, in certain sectors. This mandatory spending requires each local government to allocate minimums of $20 \%$ of its budget for education, $10 \%$ for health, $25 \%$ for infrastructure, and $10 \%$ for village funding. ${ }^{10}$ Despite this requirement, the Minister of Finance has stated that many provinces and districts did not adhere to the mandatory spending limits in 2017 (Kontan.co.id, 2017), indicating a lack of commitment to the regulations set by law.

Research has also indicated that the budgeting process in Indonesia remains problematic, with one of the largest concerns being the late approval of local budgets (see, for example, Blöndal et al., 2009; Seifert \& Li, 2015). As planned programmes cannot be executed without approved funding, budget delays may result in significant negative impacts on local government activities. Case studies on budgetary management of local government in Indonesia have been undertaken in several districts, such as Kudus district (Subechan,

\footnotetext{
${ }^{6}$ Money redistributed from central government taxes (e.g. property tax and personal income tax) and natural resources revenue (e.g. oil, gas, forestry, and mining) to provinces and regions.

7 General allocation grants (DAU) is usually used for covering the salaries of local civil servants (Act No.33/2004; Blöndal et al., 2009). Each province receives a different amount of this allocation grant, linked to the province's fiscal needs and capability.

${ }^{8}$ Specific allocation grants (DAK) are intended to meet special needs of individual regions, such as funding for recovery post-natural disaster. Provinces must apply to the central government for these grants (Blöndal et al., 2009).

${ }^{9}$ Although five regions have special autonomy status, only three provinces receive special autonomy funds. These are Aceh, Papua, and West Papua. This is based on individual agreements between the central government and each province (Republic of Indonesia, 2001a, 2001b).

${ }^{10} \mathrm{~A}$ Village Fund is a source of funds given to the local government at village level, aiming to accelerate the development in villages. Each year, the central government allocates money to the village funds through the state budget (Ministry of Finance, 2017).
} 
Hanafi, \& Haryono, 2014) and Sarmi district (Maniagasi, Bharanti, \& Christian, 2017). These studies observe that Kudus has experienced budget delays since 2006, whereas the Sarmi district budget was delayed for the fiscal years 2010 to 2012. Both these studies find that lack of commitment and budgeting competency, as well as conflicts of interest between legislative and executive government, significantly influence budget timing. Subechan et al. (2014) also note that frequent changes in budget regulations ${ }^{11}$ by central government also produced budget delays at the local level. Neither of these studies were conducted in a province receiving special autonomy funds, so my study offers this as a unique contribution. Further, as those studies were conducted using quantitative methods, investigating and understanding these issues through a qualitative approach will contribute complementary insights.

Other studies explore accountability in Indonesia's local context. These include Akbar (2011), who shows that achieving accountability in Indonesia's local governments remains challenging due to political and moral factors that are difficult to control. This, he argues, is because morality and political interest are not technical and organisational, rather embedded in people. In the budgeting context, this finding is consistent with Farhan's argument that in Indonesia, "the dynamics of the budgetary process are driven [in part] by [...] the executive's need to win support for its budgetary agenda" (2018, pp. 3-4), indicating that conflicts of interest exist within the political process of budget-making. Farhan's (2018) findings also confirm Wildavsky's (1997) statement that "the President, political parties, individual legislators, interest groups, and other social actors compete with each other to have their interests reflected in budget allocations", raising questions about the impact of these clashes in the budget-making process on the parties' ability to serve the public's interests, questions which my study addresses. For that reason, I turn next to problems in Aceh's budgetary management.

\subsection{Budgetary Management in Aceh}

Aceh is a province located on the westernmost part of the Indonesian archipelago, with five million people (Badan Pusat Statistik Aceh, 2010). It has the same governmental

\footnotetext{
${ }^{11}$ Each year, the Minister of Home Affairs updates the regulation and guidelines for preparing local budgets.
} 
structure as other Indonesian provinces, with provincial governments encompassing several municipalities and regencies. Aceh's capital city, Banda Aceh, is home to all provincial executive government agencies and the DPRA. Currently, there are 47 provincial agencies in Aceh, managing all government affairs (Pemerintah Aceh, n.d.). DPRA as the legislature holds legislative, budgetary, and control powers. Therefore, for the budgeting process, the executive, represented by Aceh's executive budget team (TAPA) is in charge of the preparation of local budget, including budget ceiling (KUA-PPAS), budget draft (RAPBA), and Aceh's budget (APBA). All of these documents need to be approved by DPRA before APBA can be implemented.

In 1976, the Free Aceh Movement (GAM) started an insurgency demanding independence from Indonesia. The history of insurgency in Aceh and subsequent negotiations with the central government is complex and its details are beyond the scope of this study. However, the 2005 peace agreement between GAM and the central government resulted in Aceh receiving greater financial resources than before the conflict began. The Memorandum of Understanding ( $\mathrm{MoU}$ ) signed between GAM and the central government in Helsinki on 15 August 2005 led Indonesia to issue Act No.11/2006 the Governing of Aceh, making significant changes to the nature of Aceh's administration, politics, and fiscal management (Basri \& Nabiha, 2016). After the MoU was signed, Aceh also enacted Shari'a law in the province ${ }^{12}$, with Act No.11/2006 the Governing of Aceh stipulating that Aceh is to ensure a kaffah (comprehensive) implementation of Shari'a law. As of 2019, there are six local agencies established engaged in implementing Shari'a in Aceh. These are:

1. Dinas Syari'at Islam (Islamic Shari'a Agency), which focuses on drafting regional regulations (Qanun) concerning Shari'a;

2. Majelis Permusyawaratan Ulama (Muslim Scholars Assembly), which provides fatwa (nonbinding legal opinions), recommendations and advice on Islamic matters;

3. Dinas Pendidikan Dayah (Islamic Education Agency), which manages traditional Islamic boarding schools (Dayah) (including facilities and students' welfare);

\footnotetext{
12 The implementation of Shari'a law in Aceh does not replace Indonesian civil law, instead it regulates aspects not covered by it, such as prohibitions of gambling and premarital sex.
} 
4. Baitul Mal, which manages and distributes zakat (alms) ${ }^{13}$;

5. Wilayatul Hisbah Aceh (Shari'a police), which assists local government in enforcing qanun; and

6. Mahkamah Syari'at (Shari'a court), which hears cases related to divorce, inheritance, gambling, alcohol consumption, khalwat (illicit contact with the opposite sex), and zina (premarital sex).

In regard to its budgetary management, Act No.18/2001 Special Autonomy for Aceh Province and Act No.11/2006 the Governing of Aceh stipulates Aceh's right to special autonomy funds (DOKA) and an increase in DAK. As of 2018, Aceh's revenue consists of local revenue (taxes, fines, zakat), natural resource revenue sharing, DAU, DAK, DOKA, and village fund (Republic of Indonesia, 2001a, 2006, 2014; Basri \& Nabiha, 2016). Aceh's public expenditure is bound by the central government's mandatory spending minimums, which are governed by Act No.17/2003 and outlined in Section 2.2. However, Act No.11/2006 stipulates that Aceh must allocate at least $30 \%$ of its revenue for education, above the national minimum of $20 \%$.

With such a wealth of resources, Aceh has had 13 years of opportunity since the peace agreement to reduce poverty and improve public service delivery. Yet the data in 2018 still show low levels of economic growth and high levels of poverty and unemployment, as noted in Chapter 1, signifying that Aceh still faces significant problems in its public resource management and delivery. In its 2006 report, Aceh Public Expenditure Analysis: Spending for Reconstruction and Poverty Reduction, the World Bank discusses resource allocation and management problems, including large spending on bureaucracy at the expense of development spending and budget delays. Sadly, these problems remain unresolved: Aspinall et al. (2012) found that Aceh still faced substantial budget delays, in both approving and disbursing expenditure, and Basri and Nabiha (2016) also note budget delays as one of Aceh's main budgetary management problems. Table 1 shows delays since at least 2005, with exceptions for the 2014 and 2019 fiscal years.

\footnotetext{
${ }^{13}$ Zakat (alms) forms one of Islam's 'five pillars', along with statement of faith, daily Salat (prayer), fasting, and hajj (pilgrimage) to Mecca. Zakat aims to narrow down the distinction between the poor and the rich (Velayutham, 2014) and as part of special autonomy and the implementation of Shari'a in Aceh, the local government through Baitul Mal Aceh manages zakat payments.
} 


\begin{tabular}{|c|c|}
\hline Fiscal Year & Date of Budget Approval \\
\hline 2005 & 25 April 2005 \\
\hline 2006 & 5 May 2006 \\
\hline 2007 & 20 June 2007 \\
\hline 2008 & 24 June 2008 \\
\hline 2009 & 04 March 2009 \\
\hline 2010 & 12 April 2010 \\
\hline 2011 & 26 April 2011 \\
\hline 2012 & 7 February 2012 \\
\hline 2013 & 04 March 2013 \\
\hline 2014 & 31 December 2013 \\
\hline 2015 & 27 February 2015 \\
\hline 2016 & 22 February 2016 \\
\hline 2017 & 9 February 2017 \\
\hline 2018 & No approval was given by parliament \\
& (governor decree was issued on 26 March 2018) \\
\hline 2019 & 31 December 2018 \\
\hline
\end{tabular}

Table 1. Date of Budget Approval for Aceh's Provincial Government (BPKA Aceh Province, 2019)

For the 2018 fiscal year, APBA was enacted through a Governor's decree, when conflict between executive and DRPA was unresolveable. Figure 3 overleaf shows the timeline of the 2018 budget process compared to the mandated timeframe. 
Mandated Timeline

\section{January-May}

Development planning meeting (Musrenbang) at sub-district, municipality/regency and provincial level to formulate a regional work plan term as a basis for the general policy of regional budget

June

Regional government submits general budget policies - provisional budget priorities and funding (KUA-PPAS) to regional parliament

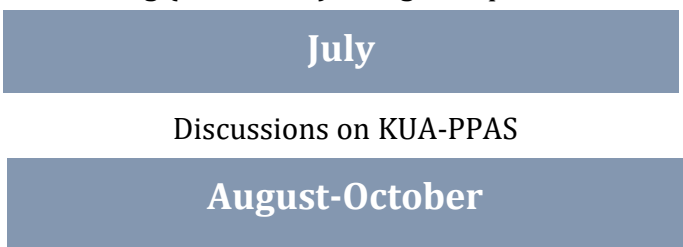

Line agencies in the region prepare work programs and budget estimates for the following year

\section{November}

Local government submits a draft regional regulation of local budget and discuss with the parliament

\section{November-December}

- Local parliament approves the proposed budget by 30 November.

- Evaluation by Ministry of Home Affairs and Local Parliament by 30 December

\section{December}

Local budget is formalized through passage of the regional regulation or Perda

\section{January- 31 December}

Budget implementation

\section{Timeline}

\section{January-June 2017}

Development planning meeting (Musrenbang) at sub-district, regency/municipality, and provincial level and formulation of a regional work plan (medium-term and long-term as a basis for the general policy of regional budget)

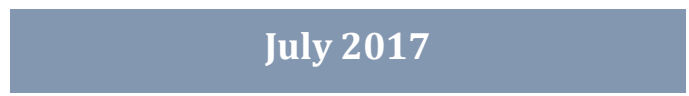

Regional government submitted general budget policies - provisional budget priorities and funding (KUA-PPAS)

\section{July 2017-February 2018}

Discussions on KUA-PPAS

\section{March 2018}

KUA-PPAS is not approved, so the Governor of Aceh issued a decree for 2018 budget with the approval of Minister of Home Affairs, implementing 2017 budget for 2018

Figure 3. Aceh's Budget Process - Mandated Timeline vs. 2018 Timeline (adapted from Act No. 33/2017 Local Budget Planning for Fiscal Year 2018 \& DPRA, 2019)

APBA approval delays have resulted in delays to project implementation and public service delivery. These delays have been criticised by scholars and local newspapers (World Bank, 2006, 2007; Aspinall et al., 2012; Basri \& Nabiha, 2016; Gatra.com, 2018; Serambinews.com, 2018a) for their negative effects on the social and economic well-being 
of Aceh's citizens. Such criticisms have prompted calls for Aceh to improve its financial planning and budgeting, not least approving APBA in good time. The discussion above shows that Aceh has significant room for improvement in resource allocation and management processes. This study aims to contribute to that improvement by offering insights from assessing its budgetary management processes through the lens of accountability theory and an Islamic perspective. It is to the second of these that I turn next.

\subsection{Budgetary Management in Islam}

Islam is derived from the Arabic words aslama and salam, meaning complete submission to Allah (God) and peace, respectively (Tahir, 1988; Lewis, 2001). Therefore, Islam means the submission of one's will (without any compulsion) to the will of Allah to achieve a state of peace (Abuznaid, 2006). In Islam, Muslims are obliged to conduct their affairs accordingly, based on the Shari'a. The Qur'an, Islam's Holy Book, and the Hadith (teachings of the Prophet Muhammad (peace be upon him)) are the primary sources of the Shari'a (Trokic, 2015; Baydoun, Sulaiman, Willet, \& Ibrahim, 2018). Furthermore, Shari'a is also based on jurisprudence consisting of the judgements of Muslim jurists and scholars on issues that are not specifically mentioned in the Qur'an or Hadith (Baydoun et al., 2018). Shari'a is universally applicable because it is "attached ... to its society, adapting to its needs, and changing with different circumstances" (Tahir, 1988, p. 169). Thus, Shari'a speaks about "satisfying the requirements of an ever-changing society" (ibid).

Muslims regard Islam as the complete guidance of life; there is no dichotomy of sacred and non-sacred activities in Islamic teaching (Afifuddin \& Siti-Nabiha, 2010). All Muslims' activities and behaviours are always bound by Shari'a (Kamla, 2009; Haniffa \& Hudaib, 2010) due to the belief that Muslims shall be held accountable for their deeds, and thus punished or rewarded, not only in the physical realm but also in the hereafter. This forms the concept of accountability in Islam based on a Qur'anic verse (4:86), "Allah takes careful account of all things". Accountability in Islam is also linked to the Islamic concept of ownership as Shari'a recognises individual, public, and state ownership (Velayutham, 2014), but since Allah is the creator and true/absolute owner of the world, such ownership is conditional and humans are stewards, or Khalifah (Kamla, Gallhofer, \& Haslam, 2006; Adnan \& Bakar, 2009; Velayutham, 2014). Furthermore, Rizk (2014, p. 198) notes, "the privilege of humankind's 
stewardship of the earth comes with a profound responsibility for the protection and care of other living species", signifying that stewardship should not be taken as licence to abuse the Earth for maximum personal benefit, but entails a sense of responsibility to ensure that activities and affairs will cause no harm to any creature on the Earth - human or animal - or to nature. Such a perspective raises numerous implications for the conduct of public officials; a significant example would be reverence for Allah and how this should ensure a high standard of conduct among public officials. Shari'a, as a comprehensive code of law and discipline, provides guidelines on governing, including the importance of being just. This is stated in the Qur'an (5:8):

0 you who have believed, be persistently standing firm for Allah, witnesses in justice, and do not let the hatred of a people prevent you from being just. Be just; that is nearer to righteousness. And fear Allah; indeed, Allah is Acquainted with what you do.

Public governance in Islam (see Naqvi, Aziz, \& Zaidi, 2011; Islam, 2012), Islamic economics (see Pryor, 1985; Zaman, 2010; Mahomedy, 2013), and Islamic accounting (see Gambling \& Karim, 1986; Khan, 2001; Haniffa \& Hudaib, 2010) have been studied extensively in the literature. Islamic public governance, for example, emphasises social justice and public welfare. Thus, Naqvi et al. (2011) developed an Islamic model for good governance based on Shari'a and academic literature, shown in Figure 4. Their model of Islamic good governance depicts the interrelation of eight dimensions of Islamic good governance, illustrating how Islam embraces fairness, justice, and transparency in its public governance. Consequently, these dimensions have implications for how a government should manage its financial resources through the budgeting process. 


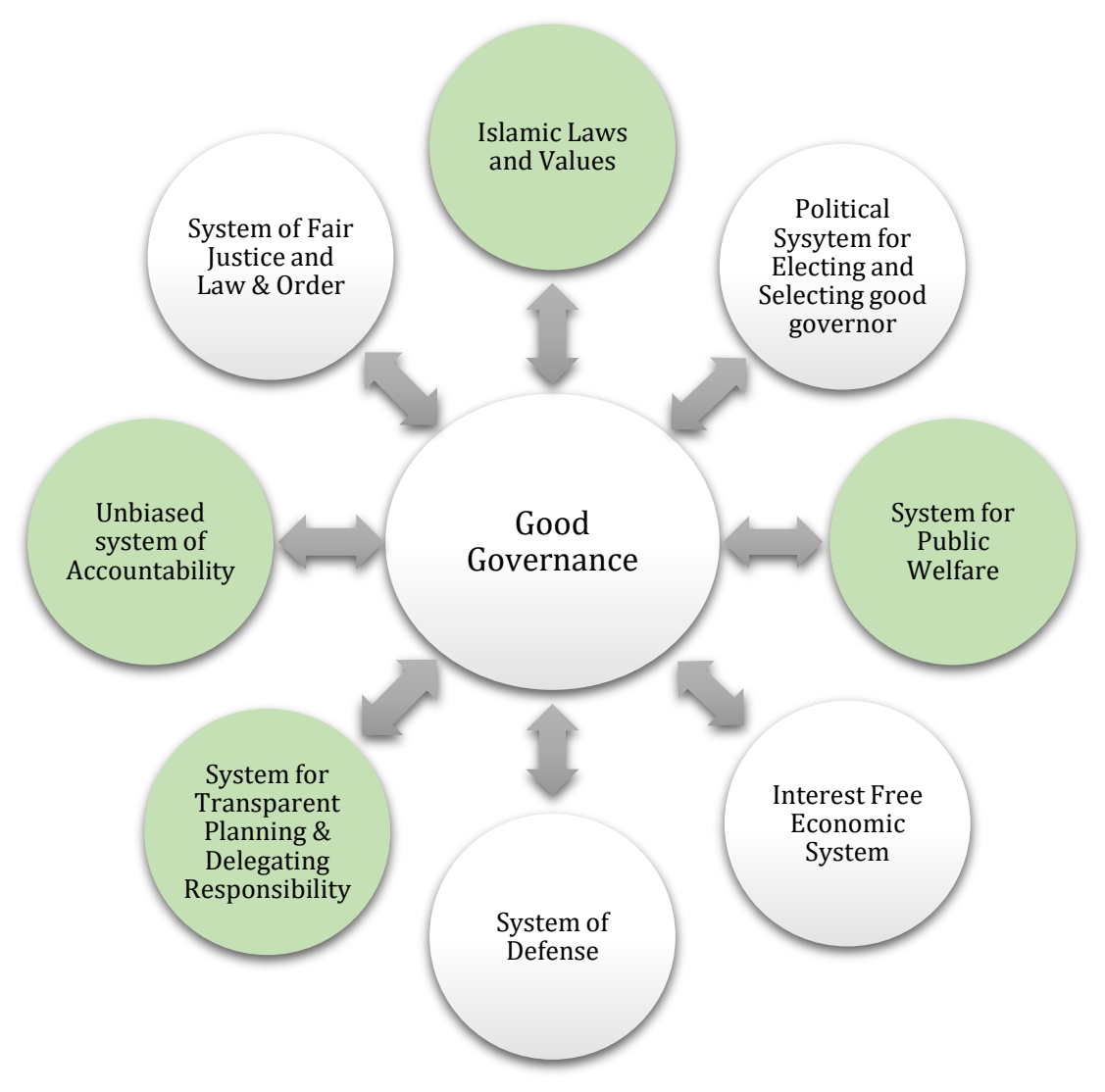

Figure 4. Islamic Model of Good Governance (adapted from Naqvi et al. (2011))

The coloured circles in Figure 4 indicate the four dimensions of the model are particularly relevant to this study. First, Islamic law and values; this refers to the adherence toward Shari'a. Second, a system for public welfare; for example the establishment during the seventh century CE of al-hisba ${ }^{14}$ to control Muslims' behaviours in the market and protect the public from fraud and exploitation through regulating market prices and supplies (Murtuza, 2000; Kamla, 2009). Third, a system for transparent planning and delegating responsibility, as Islamic teachings uphold the importance of transparency:

${ }^{14}$ Al-hisba is an institution aims to "prevent the economic exploitation of human beings at the hand of others" (Murtuza, 2000, p. 2) 
0 you who believe! when you deal with each other, in transactions involving future obligations in a fixed period of time, reduce them to writing and Let a scribe write down faithfully as between the parties (Qur'an, verse 2:282).

The above verse emphasises the importance of transparency and delegating responsibility as the parties involved in a transaction should let an independent witness and record the transaction. In the past, Umar ibn Al-Khattab, the second Caliph (Muslim leader) after the era of Prophet Muhammad, realised the importance of this aspect in the governance system, appointing al-kateeb (an accountant) to take care of finances (Kamla, 2009; Afifuddin \& SitiNabiha, 2010). Fourth, an unbiased system of accountability such that it ensures transparency and social justice so that the society will be free from fraud and exploitation (Naqvi et al., 2011; Handoko \& Kayadibi, 2013).

In my study, the importance of public welfare in Islamic good governance is related to ideas of creating public value. As I discussed in Section 2.1, creating public value follows from prioritising public interest, making this consistent with Islamic good governance. Indeed, Khan (2001, p. 288) regards the notion of maslahah (interest) of the ummah (society) as the basis for public expenditure theory in Islam, summarising seven general principles of public expenditure in Islam:

1. All expenditure should follow the criteria of the maslahah of the ummah.

2. Removal of hardship should take precedence over provision of ease.

3. The interest of the majority should take precedence over the interest of the minority.

4. If there is a conflict between a private interest and [a] public interest, [the] public interest should prevail.

5. If there is an option, greater loss or sacrifice should be avoided by preferring a smaller loss or sacrifice.

6. Whoever receives a benefit should also pay for the costs.

7. Something without which an obligation cannot be fulfilled is itself [an] obligation. 
Along with these principles, Khan (2001, pp. 228-229) proposes six other principles for Islamic good governance developed based on Qur'an verses, Hadith, practices of early Caliphs, and Islamic literature:

8. Public expenditure will follow the hierarchy of needs, giving top priority to daruriyyat (essentials), followed by hajiyyat (complementaries), and tahsiniyyat (desirables).

9. There should be no waste or extravagance in the public expenditure.

10. The government should not indulge in nepotism, favouritism and discrimination on grounds of ethnicity, sex, caste, or creed in matters relating to public expenditure.

11. The government should show due regard for inter-regional and intergenerational equity in its public expenditure.

12. In matters of income transfers, the government should act speedily and avoid red tape.

13. The government should remain accountable to the people and to Allah for each penny spent or withheld by it.

Principles 1, 3, 4, 8, 9, 12 and 13, are particularly relevant to this study, given Aceh's budgetary management problems, discussed in Section 2.3.

Whilst there is growing interest in Islamic accounting, the theoretical and critical dimensions of Islamic public budgeting remain under-explored, with most contemporary work focusing more on Islamic accounting in financial institutions (see Abedifar, Ebrahim, Molyneux, \& Tarazi, 2015; Kamla \& Alsoufi, 2015; Nawaz \& Haniffa, 2017; Hidayah, Lowe, \& Woods, 2019). Notable exceptions include Tahir (1988) and Khan (2001) who engage with conceptual dimensions of Islamic public budgeting. As my study concerns budgetary management by Aceh local government, in which Islamic principles and values inform the culture and norms, I consider that investigating Aceh's budgeting issues through the lens of Islamic conceptions on public budgeting will provide potentially significant contributions to the literature in Islamic accounting studies, as well as that on local government budgetary 
management. This note concludes my review of relevant literatures, and so I summarise the identified research gaps in the next section.

\subsection{Summary of Research Gaps}

The literature review discussed above shows that Aceh still has significant budgetary management problems, particularly in the budget cycle. Studies such as those by the World Bank (2006), Aspinall et al. (2012), and Basri and Nabiha (2016) show the problem of budget delays in Aceh. However, the reasons behind these delays still remain under-explored.

In its resource allocation, with the wealth of financial resources received after the signing of MoU Helsinki, Aceh was afforded many opportunities to improve its citizens' welfare. However it is still criticised today for its inability to allocate budgets efficiently and effectively, with data showing significant problems in the social and economic well-being of Aceh's citizens, including poverty, unemployment, and low economic growth. Therefore, as the budget timeline affects projects' implementation and public service delivery, investigating the issue of budget delays is important to understand the extent of its impacts.

The literature reviewed on budgetary management in Islam showed that Muslim leaders are expected to prioritise public interest in their budgetary management, as depicted in Khan's (2001) framework on public expenditure and the model of good governance developed by Naqvi et al. (2011). Further, Islamic concepts of accountability also expect public officials to establish a high standard of conduct. Thus my study is motivated by this apparent contrast between Aceh's difficulties in its budget process and the expectations of an explicitly Muslim government. As Islamic values and principles are embedded in Aceh's culture and norms, with Shari'a also enacted, I take this opportunity to examine the budgetary management of Aceh through an Islamic perspective. This enables me to investigate the extent of Islamic teachings in Aceh's public budgeting to gain futher understanding on the challenges of implementing such ideas in practice through addressing the following research questions:

RQ1: What are the reasons behind the late budget approval in Aceh?

RQ2: What are the impacts, if any, of late budget approval to the budget execution?

RQ3: Does the budgetary management in Aceh local government represent a good implementation of Islamic principles and values? 

a. If yes, how so?
b. If not, why not?

Having presented a review of literature for this study, in the next chapter I continue by presenting its theoretical foundation in Chapter 3. 


\section{CHAPTER 3 THEORETICAL FOUNDATION}

A theoretical foundation is crucial to define the directions of research and increase the level of confidence in the research findings as it shows how the findings relate to the theoretical aspects (Grant \& Osanloo, 2014). This study employs accountability theory as its theoretical foundation. I consider accountability theory appropriate for this study to illuminate how budget processes should be managed in the public sector context, as it engages with the complexity of the public sector where multiple stakeholders ${ }^{15}$ are involved. This chapter therefore discusses concepts of accountability related to good governance in terms of their significance for budgetary management. Concepts and debates around accountability in the public sector are followed by an explanation of one framework, B\&T's (1999) Sociology of Worth (SoW). This framework has been selected for its analysis of accountability through the justifications provided by participants. The chapters concludes with a summary and discussion of how this approach relates to the case of Aceh's budgetary management.

\subsection{Accountability: Concepts and Debates}

The term 'good governance' emerged in the 1980s (Kemp et al., 2005; Maldonado, 2010) and brought new views and ideas into public sector management on providing positive impacts to society's well-being (Rothstein, 2012). In the public sector generally, 'good governance' is defined as a set of processes, institutions, laws, and values which determine how a government should govern and accommodate diverse interests of its stakeholders (UNESCAP, 2006; Owechi \& Namara, 2012; Keping, 2018). Thus, good governance can also be seen as a continuing process which involves coordination and interaction. Nonetheless, it should also take into account that good governance will vary across cultures and religious background. An example of this is the discussion in Chapter 2 of how good governance is conceptualised in Islam.

Most definitions of good governance consider it important for governments to have improved accountability (see e.g. Kemp et al., 2005; Bovens, 2007; Maldonado, 2010;

\footnotetext{
${ }^{15}$ Including, inter alia, the public, government officials, politicians, businesses, and civil servants.
} 
Bergsteiner, 2012; Keping, 2018) because accountability can be used as a strategy to manage expectations, ${ }^{16}$ to evaluate performance, and to strengthen relationships between a government and its stakeholders. The World Bank (n.d.) identifies five key dimensions of good governance in the public sector, namely:

1. Structure of government;

2. Structure of the accountability and contestability of political leaders;

3. Public sector management;

4. Open entry and competition in private sector;

5. Nexus of issues dealing with civil society, voice and participation.

The components of good governance remain contested, however. For example, Brunet and Aubry (2016) offer three dimensions of good governance, namely efficiency, legitimacy, and accountability. Keping (2018) then adds to these a further three dimensions: transparency, rule of law, and responsiveness. Whilst scholars differ on the elements of good governance, accountability remains a central dimension in most of its conceptions, making it an oft-discussed topic in public administration literature (see e.g. Uhr, 1993; Schedler, Diamond, \& Plattner, 1999; Romzek, 2000; Bergsteiner, 2012; Almqvist et al., 2013).

Despite the volume of discussion, there is as yet no single or precise definition of accountability and its implications, not least because of the plethora of perspectives on the topic, giving rise to the argument that the very concept of accountability in public sector is elusive and vague to understand (Koppell, 2005; Bovens, 2007; Dormer, 2018). However, among the definitions of accountability argued by scholars, key recurring themes are responsibility and relationship. Gray, Adams, and Owen (2014, pp. 7-8), for example, explain that:

accountability is a duty to provide information to those who have a right to it. It is linked closely with the notions of (social) responsibility and is an essential component of democracy. The greater the power an individual, or an organisation, has over people, resources, communities, etc., the greater the

\footnotetext{
16 This aspect of public sector accountability was explained by Romzek and Dubnick (1987), noting that
} accountability can be used to establish internal and external sources of control. 
responsibility to provide a full account of stewardship of those people, resources or communities.

In this sense, accountability is not only concerned with ex post scrutiny but also with ex ante (prevention and anticipation) obligations (Bovens, 2007; Bergsteiner, 2012), meaning that one is not only accountable for past actions or behaviours, but also for future actions. The connection between responsibility and accountability has long been argued by scholars (see e.g. Uhr, 1993; Sinclair, 1995; Mulgan, 2000; Koppell, 2005; Bergsteiner, 2012), indicating that good public accountability cannot be achieved without responsibility.

The second theme of accountability most strongly expressed by scholars is that of relationship. Bovens (2007, p. 450), for example, argues for accountability being understood as a relationship between an actor and a forum. In such relationship, he mentions that there are three elements involved: the actor's obligation to inform and present to the forum regarding their conduct or actions. The forum interrogates the actor on the information presented, judges the actor's conduct, and gives approval or imposes sanctions. Whilst appealing, Boven's (2007) framework may be too linear to adequately address the complexity of accountability in today's public sector. Under good governance concepts, the structure of government becomes more complex as multiple stakeholders become more involved in government activities (Brunet \& Aubry, 2016), indicating that the government can be held accountable in multiple fora, not just one.

Notwithstanding such complexity, accountability plays a crucial role in the relationship between citizens and government because accountability acts "in ways that are broadly approved by the community" (Hughes, 2012, p. 240). Despite its limitations, Boven's (2007) framework of accountability captures the meaning of 'being accountable' as an obligation to respond to questions from those with entitlement to do so. Thus, there is a sense of dialectic relationship between these parties (actor and forum), that "accountability means that people can 'count on one another' to keep performance commitments and communication agreements [...]. Accountability is the basis for having an environment of trust, support and dedication to excellence" (Samuel and Novak, 2001, cited in Bergsteiner (2012, p. 206)).

These notions on responsibility and relationship in accountability, in some ways, represent the concept of answerability. According to Romzek and Dubnick (1987, p. 228), 
answerability in public sector accountability means that the government will provide information about their actions. Answerability, then, involves justification, leading me to the second part of my theoretical framework, B\&T's (1999) Sociology of Worth, presented in the next section.

\subsection{Accountability in the Public Sector: A Sociology of Worth Framework for Analysing Justifications}

Sociology of Worth (SoW) was developed by B\&T through their work on The Sociology of Critical Capacity. It emphasises the relationship between people and things, or situations, in the social world which can develop into disputes when a demonstration of discontent turns into a discussion; frequently, criticisms, blame, and grievances will be exchanged (B\&T, 2006). In this study, for example, the disagreements between the DPRA and the executives on the proposed budget would form a situation. To analyse these, B\&T's (1999, p. 360) framework outlines three characteristics:

1. Persons involved in the situations are subjected to an imperative of justification;

2. The situations are transitory; and

3. Disputes involve not only human persons but, also, a large number of objects.

As my study explores accountability through the dimensions of responsibility, relationship, and answerability, B\&T's insights on the imperative of justification suit the context of this research. In the SoW framework, the imperative to justify forms a crucial dimension, wherein anyone who provides criticisms needs to give justifications for their criticisms just as the criticised needs to provide justifications for their conduct (B\&T, 1999).

Further, "justifications have to follow rules of acceptability", which, in the analysis of disputes, should be the same for both parties (B\&T, 1999, p. 360), resonating with the dialectic relationship and communication agreements in accountability theory (Bergsteiner, 2012) discussed above. B\&T explain that: 
[p]eople do not ordinarily seek to invent false pretexts after the fact so as to cover some secret motive [...] rather they seek to carry out their actions in such a way that these can withstand the test of justification (B\&T, 2006, p. 37).

In other words, people in their interaction and engagement with others are naturally motivated to act and behave in a manner that is justifiable (Annisette \& Richardson, 2011).

In the SoW framework, relationships in the social world fall under six qualifications of worth called orders of worth, outlined in in Table 2 below:

\begin{tabular}{|c|c|c|c|c|c|c|}
\hline Order: & Inspiration & Domestic & Civic & Opinion & Market & Industrial \\
\hline $\begin{array}{l}\text { Mode of } \\
\text { Evaluation }\end{array}$ & $\begin{array}{c}\text { Grace, } \\
\text { nonconformity, } \\
\text { creativeness }\end{array}$ & $\begin{array}{l}\text { Esteem, } \\
\text { reputation }\end{array}$ & $\begin{array}{l}\text { Collective } \\
\text { interest }\end{array}$ & Renown & Price & $\begin{array}{c}\text { Productivity, } \\
\text { efficiency }\end{array}$ \\
\hline $\begin{array}{l}\text { Format of } \\
\text { relevant } \\
\text { information }\end{array}$ & Emotional & $\begin{array}{c}\text { Oral, } \\
\text { exemplary, } \\
\text { anecdotal }\end{array}$ & $\begin{array}{c}\text { Formal, } \\
\text { official }\end{array}$ & Semiotic & Monetary & $\begin{array}{c}\text { Measurable: } \\
\text { criteria, } \\
\text { statistics }\end{array}$ \\
\hline $\begin{array}{l}\text { Elementary } \\
\text { relation }\end{array}$ & Passion & Trust & Solidarity & Recognition & Exchange & $\begin{array}{l}\text { Functional } \\
\text { link }\end{array}$ \\
\hline $\begin{array}{l}\text { Human } \\
\text { qualification }\end{array}$ & $\begin{array}{l}\text { Creativity, } \\
\text { ingenuity }\end{array}$ & Authority & Equality & Celebrity & $\begin{array}{l}\text { Desire, } \\
\text { purchasing } \\
\text { power }\end{array}$ & $\begin{array}{c}\text { Professional } \\
\text { competency, } \\
\text { expertise }\end{array}$ \\
\hline
\end{tabular}

Table 2. Orders of Worth

(adapted from B\&T (1999))

Table 2 shows the criteria for each order of worth. First, for the worth of inspiration, the supreme worth depends on the state of grace, thus it considers emotions as its relevant information (object). In this order, the subjects are, for example, spirits, children, and artists. Second, in the order of domestic worth, people's worth depends on a hierarchy of trust, making the political connection between people and face-to-face relationship especially important. Third, the order of civic worth refers to the world where public interest becomes a higher priority than personal interest. Fourth, in worth of opinion, the worth depends on public regard and recognition. The final two orders of worth are market and industrial; the 
former assigns worth based on market performance, while the latter assigns it on efficiency, measurements, and expertise. These different orders of worth, then, determine the justifiability of different actions in different contexts (B\&T, 1999; Annisette \& Richardson, 2011).

This study considers two orders of worth, civic and domestic (highlighted in Table 2), the most appropriate to explaining and analysing the problems of Aceh's budgetary management. In the public sector, the primary order of worth is arguably civic worth, as in this order, civil peace depends on leaders who can justify that they sacrifice personal interest for the benefit of the public's interest (B\&T, 1999; Annisette \& Richardson, 2011). However, Le Maître (2006) argues that, owing to the complexity of relationships involved, the public sector can also be categorised within the order of domestic worth. In some cases, leaders in certain government agencies are appointed (by the president/prime minister/governor), not elected by the public, indicating a hierarchy of trust. In this order, trust plays an important role in relationships, supporting Goddard's (2004) argument that trust is very influential in constructing perspectives of accountability.

From the discussion above, SoW's concept of justification resonates with accountability's themes of responsibility, relationship, and answerability as SoW regards 'justification' as a significant feature in social relationships. However, despite the relevance of justification to accountability, the framework is as yet under-explored in the accounting literature. Annisette and Richardson (2011) suggest this may be due to the difficulties in understanding SoW's concepts on social world and phenomena. Nevertheless, applying the SoW framework to accountability, especially given its emphasis on justifications, can provide several new and alternative viewpoints to accounting studies: it explores the nature of relationships in the social world; it provides a framework for analysing disputes within relationships; and it highlights the importance of justifications in relationships, enriching the idea of 'being accountable'. These lead me to employ an SoW 'lens' to accountability theory as my theoretical framework to investigate the problems of Aceh's budgetary management. The next section therefore, relates this theoretical framework to Aceh's budgetary management. 


\subsection{Situating the Theoretical Framework in Aceh's case}

The discussion above shows that defining and mapping the concept of accountability is a complex and arduous task. This complexity is multiplied further when applying accountability concepts to the public sector. In the $21^{\text {st }}$ century, as countries move toward good governance, they move away from bureaucratic and hierarchical systems to decentralised and networked systems allowing more collaborative work addressing public policy problems (O'Leary, 2015). Figure 5 illustrates the difference between the hierarchical and networked models:
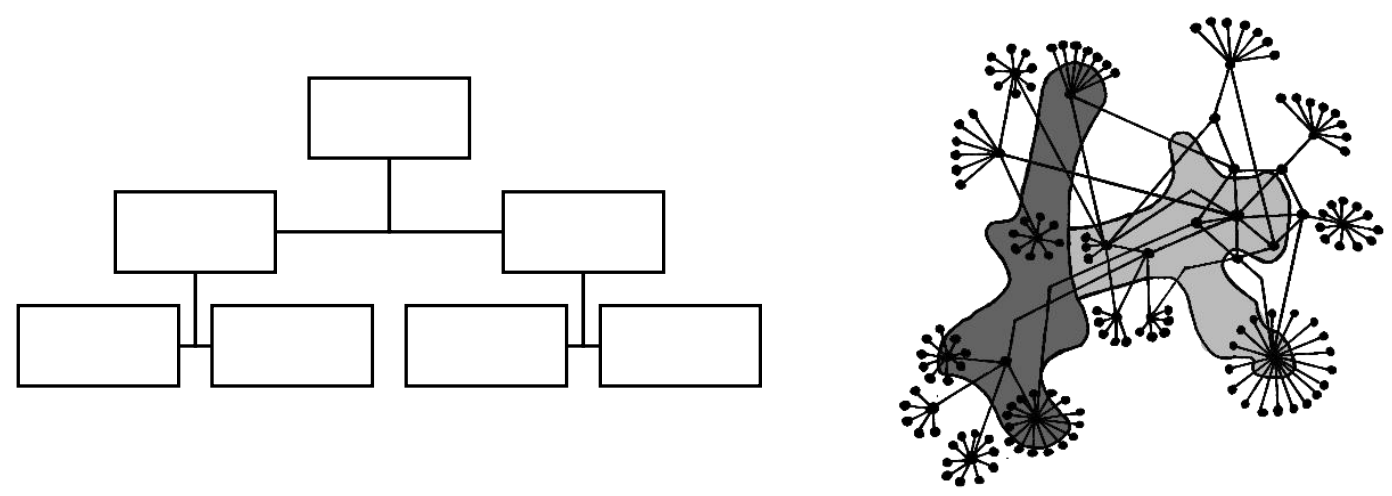

Figure 5. Classical Hierarchical and Networked Model of Organisations (adapted from Bergsteiner, 2012)

In the hierarchical model, each actor is responsible to their superior, fitting with Boven's (2007) accountability framework in which an actor is responsible to a single forum. Meanwhile, the networked model illustrates the complexity of relationships in organisations where there are multiple internal and external relationships involved, leading to more challenging and complex accountability issues. In a networked model, argues Bergsteiner, (2012, p. 205) "reporting lines are more ambiguous, temporary alliances may be made, and actions are guided more by the merits of a case compared to the bureaucratic system", consistent with Farhan's (2018) argument, discussed in Chapter 2, that there are multiple power and relationships involved in government activities like budgeting process. Therefore, the networked model better suits the concepts of B\&T's framework because SoW recognises different factors in determining one's worth(s) and his/her justifiability depending on the 'merits of a case'. 
In the public sector, the budget process plays an important role in maximising public welfare and works as a crucial element in ensuring the accountability of a government (Goddard, 2004), since the annual budget cycle forms a preeminent practice in achieving public accountability. According to Goddard (2004, p. 558), "[The annual budget cycle] contributed to all accountability relationships and ensured complementarity between them", ensuring and determining policies and objectives of the government in order to achieve good public accountability. Using accountability theory with SoW as the theoretical framework offers unique insights into the problems of budgetary management in Aceh. By employing the lens of SoW, we are able to see how different actors in different relationships within the public sector justify their decisions and conduct for Aceh's late budget approval. We can also see how the different orders of worth apply in the case of Aceh's local government's budgetary management.

\subsection{Summary}

This chapter presented the theoretical foundation used to analyse the findings of this study. It began with a discussion on concepts of and debates about accountability, noting different perspectives of scholars in defining accountability. From the multitude of possible definitions, a theme arose of accountability being concerned with responsibility, relationship, and answerability. Responsibility suggests the importance of ex ante obligations, referring to prevention and anticipation, meaning that improved accountability in the public sector could not be achieved without responsible actions from its actors. The second dimension, relationship, concerns accountability as a dialectic process between public sector stakeholders; "being accountable" in this context captures the obligation of a government to inform multiple fora about policies and conducts. Thus, the government is expected to respond to the questions asked, which leads to the third dimension, answerability, which involves the justifications provided. The justifications depend, of course, on different interests and backgrounds because people, naturally, argue, act, and behave in such a way that can be accepted (Annisette \& Richardson, 2011).

In order to analyse the justifications at work in Aceh's budgetary management, I employ B\&T's SoW framework. This framework categorises justifications through six orders of worth: inspiration, domestic, civic, opinion, market, and industrial. Among these orders of 
worth, I consider civic and domestic worth are the orders most relevant to analysing problems of Aceh's budgetary management, as the context of public sector budgeting arguably falls under these categories - civic duty and hierarchy of trust. To this end, the following chapter turns to discussing the research methodology used to address my research questions. 


\section{CHAPTER 4 RESEARCH METHODOLOGY}

This chapter explains the research methodology employed in this study. It begins by discussing its research paradigm to provide insight to its philosophical underpinnings, a crucial viewpoint in conducting research. The chapter then describes the research design, the data collection techniques used, and the process of data analysis. Research ethics and data confidentiality are discussed before a final chapter summary.

\subsection{Research Paradigm}

A research paradigm has been defined as "[...] a general perspective or way of thinking that reflects fundamental beliefs and assumptions about the nature of a field of inquiry" (Gioia \& Pitre, 1990, p. 585). Thus, it is a worldview which guides researcher in identifying their own ontological and epistemological standpoints underpinning their choices of research methodologies (Guba \& Lincoln, 1994). This means that a researcher's perspectives of a 'field of inquiry' influences how he or she conducts research.

Crotty (1998, p. 10) describes ontology as "[T] he study of being. It is concerned with 'what is', with the nature of existence, with the structure of reality as such." Hence, what we think of the nature of reality or existence shapes what we think about truth, depending on where our perspectives fall along a continuum between the objective and the subjective (Norum, 2008). Broadly speaking, ontology may be divided into realism (objective) and relativism (subjective) (Crotty, 1998; Andrews, 2012). Realists regard truth as unchanging and objectively measurable. Thus, for realists, research aims for findings that are generalisable due to their perception of 'truth' being universal (Norum, 2008). In contrast, relativists regard truth as being created through meaning and experiences (Andrews, 2012). Hence, there are multiple versions of 'truth' depending on context and generalisation of research findings is inappropriate.

Whilst ontology refers to how we see the world, epistemology concerns the knowledge gained through one's viewpoint on reality. According to Crotty (1998, p.8), epistemology deals with "the nature of knowledge, its possibility, scope, and general basis". Therefore, a researcher's ontological beliefs will influence his or her epistemological beliefs which then structure how generating knowledge should be approached, whether through objective, 
subjective, or constructive approaches (Crotty, 1988). For this study, my ontological perspective views accounting and accountability as value-based activities encompassing social, moral, spiritual, and material aspects, leading me to use a subjective epistemological approach to understand the investigated phenomenon. Such epistemological approach is usually conducted through qualitative research because qualitative approach provides greater insight into the phenomenon under investigation, gaining more in-depth information that is difficult to convey quantitatively (Knodel, 1997; Neale, Thapa, \& Boyce, 2006). Therefore, interpretive qualitative research is discussed briefly in the next section.

\subsection{Interpretive Qualitative Research}

Qualitative research is suited to "understanding how people interpret their experiences, how they construct their worlds, and what meaning they attribute to their experiences" (Merriam \& Tisdell, 2015, p. 15). The research questions in this study (see Chapter 2) deal with how and why questions - therefore, qualitative methods offer the most suitable approach. Unlike quantitative research, no statistical analyses are used in qualitative research. Instead, the research uses mainly induction, a recursive and reflective process with continuous interaction between theory and data, for its data analysis process (Hoepfl, 1997). This analysis is then presented through "richly descriptive" words, together with figures and pictures (Merriam, 2009, p. 16).

In this study, to gain a deeper understanding of Aceh's budgetary management, I employ an interpretive approach. Interpretive approaches in qualitative research view social phenomena as different from natural phenomena, regarding the social world as dynamic and requiring constructive interpretation to understand (Chua, 1986; Morgan, 1988). This view is driven by its epistemological and ontological assumptions of the subjectivity of social reality, noting that the social world is constructed by human actors through their interactions with one another and their subjective interpretations (Chua, 1986). Thus, such approach is preferred to investigate 'how' and 'why' types of research questions (Adams, Hoque, \& McNicholas, 2018). The use of an interpretive approach in this study then allows me to take an active role in learning and telling the 'story' of Aceh's budgetary management from interviewees' perspectives and to understand its complexity. Moreover, I do not intend 
this study to provide conclusive or generalisable answers, rather to explore a contextspecific phenomenon and develop ideas for input to future decision-making and research.

In qualitative research, research designs are emergent rather than predetermined because they are treated as a reflexive process throughout the research project (Hoepfl, 1997; Maxwell, 2012). The next section therefore discusses how my research design developed.

\subsection{Research Design}

Research design is the 'blueprint', action plan, or strategy for conducting research (Kelliher, 2011; Yin, 2016). In qualitative research, the research design is usually treated as a restropective feature rather than fixed because of the recursive nature of this type of research (Yin, 2016). There are no precise numbers of choices in qualitative research approaches as it has no rigid formats to be followed (Berry \& Otley, 2004) and so a qualitative researcher requires flexibility and openness to the possibility of discovery. However, Creswell and Poth (2018) suggest five basic approaches in qualitative research, namely narrative research, phenomenology, case study, ethnography, and grounded theory.

With the research questions in mind, I opted to employ a qualitative exploratory case study approach, with an interpretive data analysis as it enables me:

1. to deal with multiple sources of evidence, such as document analysis, informant $[\ldots]$ interviewing, [...];

2. to deal with a detailed description of [...] processes and how [they] affect participants in practice;

3. to analyse the strengths and the weaknesses of processes reported by the people interviewed;

4. to discover how the experience, words, feelings, attitudes, and value judgment of the participants [...] are implicated in the research questions; and

5. to capture individual differences or variations in perceptions about the realworld practice.

(Adams et al., 2018, p. 488) 
Further, the purpose of exploratory case studies is to gain a deep understanding of the investigated phenomena not to provide conclusive answers to the investigated phenomena (ibid), making it a suitable design for this study.

In case-based study research design, a researcher usually starts by formulating research questions ${ }^{17}$, then considers how to research them (Mason, 2018). Figure 6 illustrates the research design of this study. It started with identifying research gaps through literature review and a theoretical framework suitable to addressing these, leading me to then formulate research questions for this study. After that, I addressed myself to gaining access for field work since this is crucial to the success of a case study. I initially approached two scholars and a government advisor, asking about the possibility of conducting field work in Aceh. All three responded positively and I commenced with a human ethics application, followed by developing and performing data collection strategies. The data collected through interviews and written materials were then analysed through an interpretive approach to address the research questions of this study. Finally, I analysed the findings with theory chosen (accountability theory).

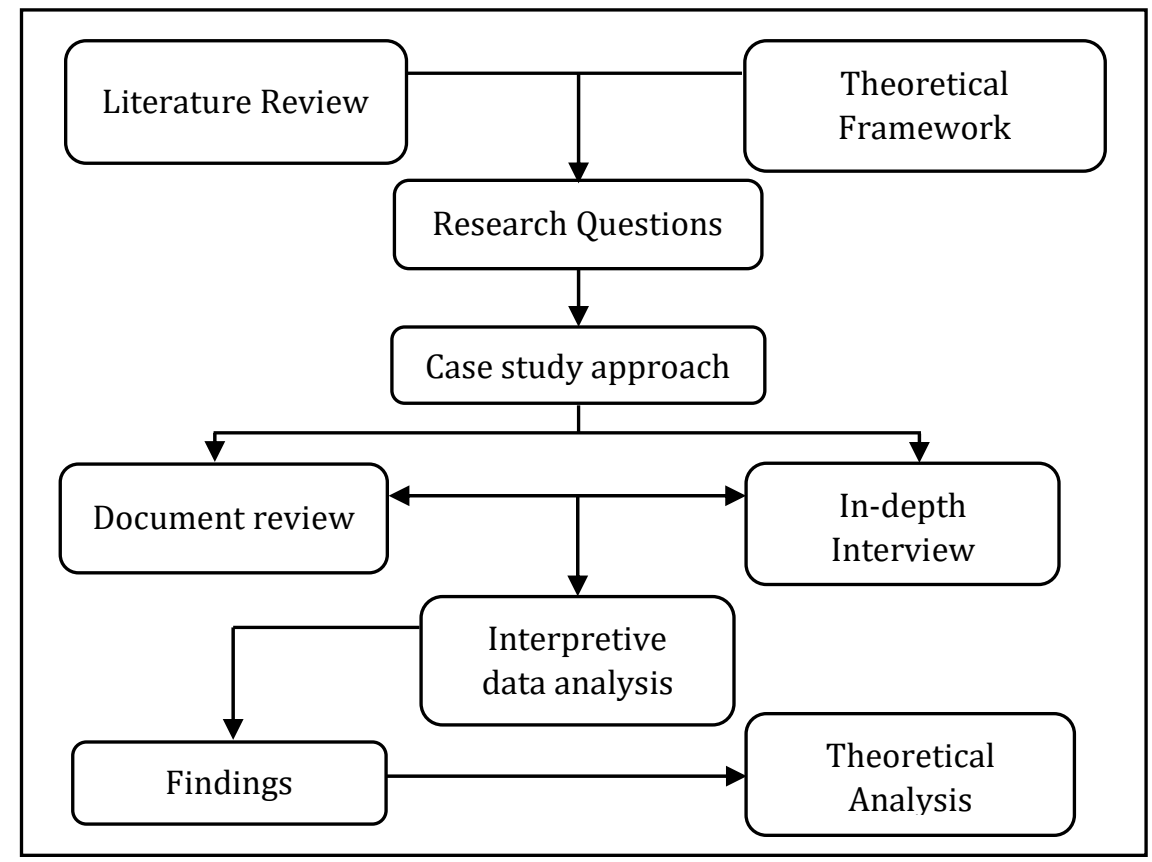

Figure 6. Research Design

${ }^{17}$ Although these often evolve during the course of a study due to the continuous interaction between theory and data. 
Having presented my research design for this study, the next section, outlines the data collection techniques employed in this study.

\subsection{Data Collection Techniques}

Case studies typically employ a variety of techniques for collecting data, with the main methods being interviews, observation, field notes, and the study of documents (Hoepfl, 1997; Yin, 2016). The techniques employed in this study were interviews, informal conversations during fieldwork, and a study of documentary materials, discussed further below.

\subsubsection{Interview}

In this study, most interviews were semi-structured. Unlike a structured interview where all questions are scripted in advance, a semi-structured interview forms a series of open-ended questions, allowing the interviewer to extend questions according to the interview's context and setting (Yin, 2016). I chose this type of interview because it provided greater opportunities for discussing topics in more detail by asking follow-up questions based on interviewees' responses. However, I also conducted a few unstructured interviews where questions were framed on the basis of the interviewee's previous responses. To ensure that all the research questions of this study were addressed, I prepared a complete linkage between the research questions and the interview questions (see Appendix B) ${ }^{18}$ for use as a guideline.

The selection of interviewees in this study was based on both purposive ${ }^{19}$ and snowball sampling. ${ }^{20}$ These sampling techniques are used extensively in qualitative research as they identify and select information-rich participants related to the phenomenon of interest (Palinkas, Horwitz, Green, Wisdom, Duan, \& Hoagwood, 2015; Sekaran \& Bougie, 2016). This is also consistent with the nature of a case study in which it is unlikely to know with precision

\footnotetext{
18 The number of questions asked from this guideline varied, depending on the interviewee's responses. Interviewees' answers often addressed several questions at a time.

${ }_{19}$ Purposive sampling, also known as "criterion-based sampling" (Ritchie, Lewis, Lewis, Nicholls, \& Ormston, 2013, p. 144), selects a sample based on criteria set by the researcher, such as job role. This technique is considered appropriate when the researcher needs to obtain information from a specific group of people (Sekaran \& Bougie, 2016).

${ }^{20}$ Snowball sampling is a non-probability-based sampling technique in which the researcher recruits his/her respondents through contact information given by other respondents (Noy, 2008).
} 
or certainty about the research setting at the beginning of a research project. For this study, I selected the participants based on their roles and capacity to address my research questions. In total, I interviewed 19 people between December 2018 and February 2019. The interview duration varied from 30 to 120 minutes. All interviews were conducted in Banda Aceh, capital of Aceh province. The people interviewed were four members of DPRA, four officers of local government agencies, one auditor, four scholars in accounting and economics studies, five scholars in Islamic studies, and one coordinator of a corruption watchdog. The people interviewed and interview types are listed in Appendix C. I also had informal conversations with scholars, government staff, and members of society other than the interviewees, enabling additional insights regarding Aceh's budgetary management. The second data source in this study was written materials; I discuss their selection next.

\subsubsection{Documents}

I gathered a wide range of written materials to gain further understanding of the problems investigated. I gathered publicly available documents, such as the Indonesian Government regulations on local government budget and the annual budget for Aceh local government. Internal records of official reports on parliamentary meetings for budget, annual reports on budget utilisation, and other relevant documents were also collected during fieldwork. The analysis of these written materials led to a deeper understanding beyond that of the interviews as documents provide "knowledge of the context in which events occur, and may enable the researcher to see things that participants themselves are not aware of, or unwilling to discuss" (Hoepfl, 1997, p. 53). This approach helped me to assess and compare the information provided in face-to-face encounters or interviews and in data analysis, which, I discuss in the next section.

\subsection{Data Analysis}

The data analysis in this study was based on a model proposed by Seidel (1998). Figure 7 shows three interlinked processes in the model: noticing, collecting, and thinking about interesting things, representing that the analysis of qualitative data is an iterative and progressive process (Seidel, 1998; Sinkovics \& Alfoldi, 2012). In other words, data analysis is not linear but cyclical and involves repetition. 


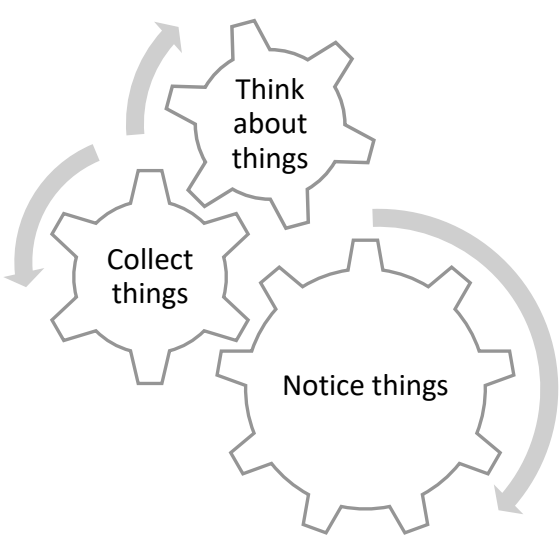

Figure 7. Data Analysis Model

(adapted from Seidel (1998))

Data analysis in this study began by transcribing all interview data collected using NVivo. Then, I carefully coded the transcripts to identify topics and issues raised in the interviewees' narratives. I used a mixed approach of coding in this process, combining bottom-up and top-down approaches. First, for the top-down approach, I created three 'parent nodes' based on the research questions:

1. Lateness of budget approval in Aceh

2. Consequences of late budget approval

3. Islamic teachings in Aceh's budgetary management

Then, by referring to my literature review and field notes, several new sub-nodes emerged for each parent node and I coded my data against these. Then, for the bottom-up technique, I coded data by hand on a hard copy of the transcripts. I transferred this coding into NVivo, creating new sub-nodes where necessary. ${ }^{21}$ Appendix D gives a full list of nodes used. These coding and analysing stages involved an iterative process in which noticing, collecting, and thinking about things went back and forth. I compared and reviewed the transcripts of the interviews, field notes, and documents until nothing new emerged from the data, resulting in the four major themes presented in Chapter 5. For my theoretical analysis, presented in Chapter 6, I analysed the case findings (Chapter 5) through the lens of

${ }^{21}$ This bottom-up coding also yielded a new parent node (other problems in Aceh's budgetary management). 
the SoW framework outlined in Chapter 3, analysing the justifications present in my data to see the accountability issues in Aceh's budgetary management.

In data analysis, it is important to employ a strategy to increase the confidence of the findings and manage biases. Therefore, I continue my discussion next to data triangulation, a technique to maintain and increase trustworthiness of qualitative data.

\subsection{Data Triangulation}

Interpretive inquiry denies the existence of objective reality and instead focuses on the co-construction of meanings between the researcher and the participant (Lietz et al., 2006), making questions of 'validity' and 'reliability' problematic. It is important to note that the philosophical underpinnings of interpretive inquiry do not see subjectivity as a distortion in the findings of a study (Noble \& Smith, 2014; Galdas, 2017). Despite frequent questions about the reliability of interpretations of interviewees' narratives, no statistical tests can be adopted for these issues (Noble \& Smith, 2015; Sutton \& Austin, 2015). Indeed, the term 'valid' arguably contradicts interpretive philosophical positions on social construction and multiple realities. Therefore, qualitative researchers prefer to address rigour in social research through trustworthiness, arguably a more appropriate test of research which is reflexive and subjective (Lietz et al., 2006; Galdas, 2017).

A common strategy to increase the confidence in the findings and manage bias in qualitative data analysis is through triangulation (Krefting, 1991; Lietz, Langer, \& Furman, 2006; Noble \& Smith, 2015) which helps to "produce a more comprehensive set of findings" (Noble \& Smith, 2015, p. 35) through the use of different source of data. I therefore employed this strategy in my analysis, comparing the evidence gathered from different sources (interviews, informal conversations, field notes, and documents) throughout the data analysis process with the intention of examining differences in attitude and determining whether there were areas of commonality that could lead to a compromise of views. This way, performing data triangulation is expected to help increase the trustworthiness of this study.

Having outlined my approach in data analysis, I move to discuss briefly how I addressed research ethics and data confidentiality for this study based on Victoria University of Wellington's (VUW) policy. 


\subsection{Research Ethics and Data Confidentiality}

Victoria University of Wellington's (VUW) policy is that any study involving people as research participants must be assessed by its Human Ethics Committee (HEC). Therefore, before the collecting data process began, I applied to VUW's HEC, Pipitea subcommittee, on 1 August 2018, and received approval on 27 August 2018.

During the fieldwork, all interview participants were given an information sheet and a consent form (see Appendix E) prior to the interview. I ensured they were aware of their rights as an interviewee, such as the right to choose to not participate in the research and the right to withdraw from the research. All participants were given information on data confidentiality and I have anonymised interviewees by referring to them by code (see Appendix C). Everyone approached agreed to contribute to this research. Lastly, all written documents gathered during this study, including hardcopies of transcripts, are stored in a locked storage box while the electronic data is stored on a password-protected computer. The data collected will be held until July 2024 to allow the development of further research, as approved by VUW's HEC.

\subsection{Summary}

In this chapter, I outlined my research strategies to address the research questions in this study. I began with discussing its research paradigm, justifying my choice to employ an interpretive approach as the most appropriate for this study. The reasons for this choice are it being a preferred approach to address the 'why' and 'how' types of research questions this study addresses and its ontological affinity with my own underlying philosophical assumptions.

Then I moved to explaining my research design, an exploratory qualitative case study employing interpretive data analysis. This approach was chosen its suitability to my aim of developing ideas for future decision-making and research. Next, I discussed the techniques of data collection used in this study, namely interviews, study of documents, and informal conversations during fieldwork. Then I outlined how I analysed the results through transcribing, reading, coding, interpreting, and conducting data triangulation. The results of these procedures are presented and discussed in the following two chapters. 


\section{CHAPTER 5 CASE FINDINGS}

This chapter presents my findings concerning budget delays in Aceh Province and the implementation of Islamic teachings in Aceh's budgetary management, based on the data collected from interviews and relevant documents. It begins with a discussion on the given reasons of late budget approval in Aceh before moving to the impacts of this lateness. Next, the chapter discusses whether Islamic principles and values are well-implemented in Aceh's budgetary management. The final section concludes the chapter with a summary of findings.

\subsection{Late Budget Approval in Aceh: Why Did It Happen?}

The issue of late budget approval is central to this study, with RQ1 addressed to investigating the reasons for this. According to Aceh's Financial and Property Management Agency (BPKA), the budget approval in Aceh has been consistently late, except for the fiscal year 2014 and 2019 (see Table 1 in Chapter 2). As the public sector involves dynamics of power between government agencies, elected officials, political parties, bureaucrats, citizens, and other actors (Flink, 2018), late budget approval indicates issues in the political dynamics between stakeholders. With budgetary policy in Aceh negotiated and decided between TAPA and DPRA, politics held a significant role in the delays to getting APBA approved in a timely manner:

Why is the dynamics of local budgeting structure always undisciplined toward the timeline? Well... it is because there was a dimension of local political issues, one of which is conflict of interest (NG001).

These issues of political interaction and multiple/conflicting interests in the budgeting process were also argued by other interviewees with two major themes related to the reasons for the late budget approval emerging from this study's data. The first of these was the political interaction between executives and MPs and the second was conflicts of interest around the Aspiration Fund (AF). I discuss these in turn below. 


\subsubsection{Political interaction between Aceh's executives and DPRA}

In practice, the process of approving the Aceh local budget emphasises its political factors more than the idea of preparing the government budget through an economic approach in the interests of the public (NGO01).

Public interest is a key consideration in public sector budgeting, especially in the era of good governance. However, as Norton and Elson (2002) and Bräutigam (2004) argue, political factors tend to create conflicts of interest between governmental actors. Whilst this is an inescapable aspect of public sector budgeting, the larger question in this study concerns the extent of its involvement in the budget approval delays.

It is indeed difficult to have a clear view of what is needed by people. Perhaps this is why the definitions of many terms in public budgeting seem vague and unclear, such as public value and public interest, because they are open to different interpretations. S01 expresses this difficulty:

[In the] local budgeting process, we [executives] usually use the economic approach in our preparation. We calculate the budget input, budget output, and we even analysed the cost benefit. Every single thing was calculated carefully. All the programmes that have been calculated were then proposed to DPRA. [At this point] they will analyse the proposed budget using a political approach

which means that there is this tendency to move towards the interest of any particular group involved in the discussion. Ideally, we believe that public interest should be the base of any decision made. Well, in reality, group interests seem to be more important.

In other words, a political approach was more dominant than economic and accounting approaches within the budgeting process. DPRA's and the executives' viewpoints seemed to diverge greatly on where the public interest lay, creating different political interests between MPs and the executives. MPs considered themselves as representatives of their constituents, setting their priorities in the budgeting process whilst, at the same time, the heads of the executive, the Governor and Vice-Governor (who are also directly elected) had their own 
priorities $^{22}$ for their term in office. These different political interests tended to create conflicts of interest and communication problems between DPRA and the executive. Many of my interviewees referred to communication problems between DPRA and executives as a reason for the budget delays, for example:

So, I regard that this regional budget delay was due to political factors and resulted in ineffective communication between executive and legislative governments (S02).

Further, scholar participants and NGO01 argued that such a conflict of interest and communication difficulties were caused by the tendency of the two government institutions to defend their own power in the budgeting process.

In the 2018 fiscal year, for example, TAPA submitted KUA-PPAS, the first document in the budget cycle on 31 July 2017, for discussion by DPRA. According to Ministry of Home Affairs Regulation No 33/2017 Local Budget Planning for Fiscal Year 2018, KUA-PPAS should be submitted in early June 2017 and approved by DPRA by 31 July 2017. Thus, the budget process was already late from its beginning. Unlike in previous years when KUA-PPAS proposed was still approved by DPRA, albeit late, TAPA and DPRA failed to achieve an agreement on this document by March 2018, three months into the next financial year. This prevented TAPA from continuing to the next step of preparing agencies' budget and work plans (RKA) and RAPBA. To break the deadlock, a Governor's decree repeating the 2017 budget was issued and approved by Minister of Home Affairs on 26 March 2018.

The Governor's decree made DPRA feel bypassed by the executive government:

DPRA assumed that the executives were glad when the governor decree was approved [by the Minister of Home Affairs]. [The executives would think that] "Oh, we do not need the DPRA any longer; we can have anything we propose approved without DPRA's approval" (LG03).

However, executives interviewed explained that the decree was issued because they needed

22 These priorities are captured in vision and mission statements and accommodated in RPJM (medium-term development plan), influencing the types programmes/projects allocated in APBA. 
to advance the budgeting process as DPRA kept delaying the negotiations and insisting on including programmes and projects outside provincial authority (e.g. road maintenance in villages) through the AF. While the issue of tough discussion on the AF in 2018 was acknowledged by one MP (LG03), another argued:

Well, at that time, when we reviewed the proposed programmes, [they] were not in accordance with RPJM [medium-term development planning]. They were not even in the RKPA [Aceh government-wide work plan]. Most of the programmes were not supposed to be there. So, we demanded the executives revise the programmes, but they did nothing (LG01).

This concern over budget plans prepared by the executives was also raised by some scholars and NG001. These interviewees mentioned that the agencies had other issues in their planning, especially with their databases, including demographic data and data on past performance. One participant, an advisor to the Aceh Development Planning Agency (BAPPEDA) who is also a scholar, argued that a lack of data was one of the main problems in Aceh's budget planning:

Aceh is one of the provinces with a poor database. Due to this poor database, the newly appointed government does not know where and what to start in their budgeting (SE04).

Furthermore, the RPJM (medium-term development planning) and RPJP (long-term development planning) documents were often taken for granted and rarely used as indicators and guidelines in preparing APBA. Consequently, there was little integration or communication between agencies in the planning processes, leading to a tendency to copy the previous programmes and projects with only minor adjustments. Two MPs interviewed, LG01 and LG03, argued that these issues were DPRA's main concerns throughout KUA-PPAS discussions, causing them to not want to easily approve the proposed KUA-PPAS.

As the problem of late budget approval started long before 2018, many interviewees mentioned the lack of commitment to the budget timeline by TAPA and DPRA. Whilst several 
interviewees claimed TAPA was always on time, DPRA documentation shows this not to be the case, as illustrated in Table 3:

\begin{tabular}{|c|c|c|c|c|}
\hline Fiscal Year & $\begin{array}{c}\text { Mandated } \\
\text { Date of KUA- } \\
\text { PPAS } \\
\text { Submission } \\
\end{array}$ & $\begin{array}{l}\text { Actual Date of } \\
\text { KUA-PPAS } \\
\text { Submission }\end{array}$ & $\begin{array}{l}\text { Mandated } \\
\text { Date of } \\
\text { KUA-PPAS } \\
\text { Discussion } \\
\end{array}$ & $\begin{array}{c}\text { Start of KUA-PPAS } \\
\text { Discussion by } \\
\text { DPRA }\end{array}$ \\
\hline 2017 & \multirow{3}{*}{$\begin{array}{l}\text { by } 14 \text { June of } \\
\text { prior year }\end{array}$} & 28 December 2016 & \multirow{3}{*}{$\begin{array}{l}\text { by } 31 \text { July of } \\
\text { prior year }\end{array}$} & 29 December 2016 \\
\hline 2018 & & 31 July 2017 & & 20 November 2017 \\
\hline 2019 & & 6 August 2018 & & 14 August 2018 \\
\hline
\end{tabular}

Table 3. Date of KUA-PPAS Submission and Discussion

(DPRA, 2019)

Table 3 shows that TAPA and DPRA were each late in submission and discussion respectively of KUA-PPAS. However, it must be noted that these data were gathered from DPRA ${ }^{23}$ which only acknowledges KUA-PPAS as submitted when it is presented to the DPRA's budget committee (Banggar) meeting. Meanwhile, TAPA regarded that they had always been on time in submitting KUA-PPAS, operating under the assumption that simply handing in the document was enough. As one of TAPA's internal auditors, EXE01, said:

From the executives' point of view, we are always on time. For instance, when we have to propose KUA-PPAS, then we propose it at the right time although it might not be perfectly well-prepared. This is where the function of discussions and negotiations of KUA-PPAS [should happen]. However, the DPRA does not want to accept our submission. We don't know why.

Similarly, one MP said:

[...] there are different interpretations of whether KUA-PPAS should be proposed in the official meeting or [if] handing it in is simply enough. TAPA believes that after they hand in KUA-PPAS, they have done their part. The DPRA

\footnotetext{
${ }^{23}$ I was unable to gather any information on the KUA-PPAS submission date from TAPA because of the difficulty
} of obtaining data from their database. 
however, believes that the proposed KUA-PPAS should at least be submitted in Banggar meeting to be later approved or not. This is also another feud (LG02).

These two statements illustrate the miscommunication between TAPA and DPRA. TAPA claimed DPRA always postponed the budget meeting for KUA-PPAS whilst DPRA argued that KUA-PPAS was submitted late. This indicates that the executive government and DPRA tended to blame each other for the budget delays.

Interestingly, neither government institution seemed to attempt resolving the miscommunication issue, despite both recognising it as a problem. This led me to ask, why did the delays keep happening? LG03 answered this:

I first joined the DPRA in 2014. I see that [for MPs] lateness is something common here. This habit of lateness has become a norm and something usual, even when the deadline is close, it isn't considered a warning, and most of us would think "Oh, it's okay, we can do this later...".

This tendency to delay budget discussion was also implied by another MP who stated that:

DPRA has got a lot of other things to do apart from arranging the budgeting process. We've got to implement programmes, [we have] obligations to attend various meetings, and so many more. Thus, the discussion for the budget will be delayed as well (LG01).

This statement indicates that timely discipline in the budgeting process is not a top priority for DPRA. Nevertheless, after the 2018 budget conflicts, DPRA and TAPA tried to reconcile in order to get the 2019 APBA approved by the deadline of 31 December 2018. This was successful, with the approval achieved on that date. However, I raised another question on this issue with the participants: was this driven solely by the motivation to avoid another Governor decree or something else? I raised this because KUA-PPAS for fiscal year 2019 was discussed in under three months, compared to prior fiscal years which took over six months on average. From an informal conversation with DPRA staffers, I learnt that the discussion on KUA-PPAS and RAPBA for 2019 was less detailed than in previous years, due to the pressure to have the 2019 APBA approved on time. This was confirmed by MSE03: 
There are different kind of interests this year. We believe that [there is] a common interest to have 2019 budget approved faster than the previous ones because two big reputations are at stake in this process, the executive government's and DPRA's. However, this year is also a political [i.e. election] year where different interests [to gain voters' trust] come into play. As this process [budgeting] needs to go through DPRA, negotiations become the most important bargaining tool so that the APBA can be approved earlier. Thus, we ended up with compromises which can disrupt the well-prepared budget itself. Without any compromises, the process can be much longer [again] which later put the two institutions' reputations at stake.

NGO01 and LG03 also commented on the issue of general election as one of the factors which speed up the APBA approval. For them, this was noticeable because only the 2014 and 2019 fiscal years, which both had general elections, had APBA approved on time. They further argued that MPs wanted APBA to be approved earlier because it allowed faster implementation of programmes proposed by DPRA through AF, enabling them to campaign to their potential voters about their success/es during their term of office.

Almost all interviewees in this study highlighted the political interaction and clashes of interest between the executive and DPRA as key reasons for late budget approval in Aceh. They argued especially that discussions of KUA-PPAS were difficult to resolve due to the interest of MPs in the allocation of the AF. Indeed, NGO01 said that of all political interactions in Aceh's budgeting process, the allocation of the AF is the most significant. Therefore, I turn next to outlining its operation.

\subsubsection{The Aspiration Fund}

At the national level of government, Dana Aspirasi (Aspiration Fund) was proposed to the Indonesian parliament (DPR RI) by the Indonesian political party Golongan Karya in 2011 (Kimura, 2011; Ministry of Finance, 2015), who argued that such a scheme would accommodate aspirations from their constituents due to MPs obligation as representative of these people. At the time, many corruption watchdogs condemned the fund as pork-barrel 
spending 24 , arguing that such a scheme would provide a way for corruption through bogus programmes. This triggered many to reject this proposal, including Susilo Bambang Yudhoyono, a former president of Indonesia. After its rejection in 2011, discussion on a national fund re-appeared when new members of DPR RI were elected in 2014, but it was once again rejected (Ministry of Finance, 2015).

Nevertheless, AF had been in operation in Aceh before it was proposed at the national level. ${ }^{25}$ In Aceh, AF refers to a scheme in which MPs can propose programmes to be allocated funding in APBA under the relevant agency's budget and work plans. According to NGO01, it was first allocated in 2008 when Aceh province started receiving DOKA from the central government and proposed as bargaining power for DPRA in the budgeting process. In contrast, LG04 contended that the idea of AF was raised because many people were complaining to their MPs that the executive paid insufficient attention to their welfare. Consequently, MPs, as representatives of the people, claimed that they wanted to heed people's voices, especially those who had voted for them.

When Aceh's AF was first established in 2008, the amount of funding allocated in total was between IDR 500 million and 1 billion (NZD 50,000-100,000),26 but this has increased gradually over the years. In 2018, IDR 10 billion was allocated for each of the 81 MPs. For the head and three deputy heads of DPRA, IDR 30 billion (NZD 3 million) and IDR 25 billion (NZD 2.5 million) respectively. Lastly, IDR 5 billion (NZD 500,000) was also allocated for each of the seven factions in DPRA. ${ }^{27}$ Therefore, for fiscal year 2018, AF programmes totalled around $6 \%$ of APBA. ${ }^{28}$ Nevertheless, it is important to note that programmes allocated through AF are not executed by MPs or DPRA, but through government agencies. This is why the term "Dana Aspirasi" (AF) does not appear in the APBA document. Instead, the amount of AF refers only to the maximum budget for programmes which may be proposed by each MP, to be later executed by the appropriate agency. For example, in 2017, one MP proposed a 24-unit housing programme for low-income families with a total budget IDR 2.16 billion

\footnotetext{
${ }^{24}$ Pork-barrel spending is a term refers to "policies or legislation targeted to specific groups of voters to gain their political support" (Drazen \& Eslava, 2006, p. 1).

25 There is no evidence however, that Aceh's AF inspired Golongan Karya to propose the national fund.

${ }^{26}$ The numbers in this paragraph were all sourced from NGO01.

${ }^{27}$ Each faction consists of loose coalitions of different political parties.

${ }^{28}$ Total APBA 2018 was IDR15.194 trillion (NZD1.5 billion)
} 
(NZD 216,000). This was then included in APBA under Aceh's Housing and Settlement Agency budget (NGO01, personal communication, 04/03/2019).

As mentioned above, the AF scheme was a key reason why KUA-PPAS went through such prolonged discussion between TAPA and DPRA, perhaps because there was no regulation for the allocation and management of AF prior to fiscal year 2019. EXE01 and NGO01 both noted that MPs tended to propose programmes after KUA-PPAS was submitted, creating difficulties for executives allocating MPs' programmes in their agencies' RKA and RAPBA. Further, MPs rarely considered the separation of authority between provincial and municipality/regency in proposing their programmes (EXE01 and EXE02), with many proposed programmes being under municipality authority, creating jurisdiction clashes. These interviewees also further elaborated that most programmes proposed by MPs were types of grant or social aid with different sets of regulations in the budget allocation process.

I questioned one MP (LG03) about executives' claims of MPs proposing AF programmes after KUA-PPAS has been submitted. The MP suggested several reasons for this tendency: first, most MPs tend to underestimate APBA's timeline, linking this to how lateness was perceived as something usual and acceptable (see discussion in Section 5.2.1). From this, LG03 explained that most MPs usually worked on people's aspirations for programmes after KUA-PPAS had been submitted, then complained that TAPA did not want to allocate these aspirations in KUA-PPAS and RAPBA. A second reason argued by LG03 was the poor understanding of society leaders of the budgeting timeline. Society leaders often chose to simply ignore the budget timeline when imposing their agendas on their MPs, pressuring them to include these in APBA. Thus, to avoid losing trust from their constituents, the MPs passed on the pressure to the executives.

Almost all of my interviewees mentioned that AF was the main interest of MPs in the KUA-PPAS discussions. Although MP participants in this study argued that AF aims to accommodate public's aspirations, other participants (scholars and NGO01) indicated that AF offers possibilities for MPs to maximise their own political interest. One reason for this may be the ease of submitting bogus programmes or adding mark-ups to existing ones through the scheme, as Susilo Bambang Yudhoyono previously warned, for, according to NGO01: 'The biggest corruption source in Aceh is from AF". 
While DPRA has no right to involvement in programme execution, NG001 suggested that corruption could happen through AF schemes when MPs interfered in the process, such as deciding who should win contracts for programmes they had proposed or pressuring for mark-ups in the budget. EXE05 confirmed that such a scenario had happened. LG04 agreed this could happen because, in their view, MPs often misunderstood the operation of AF, believing that these programmes were 'their' programmes. However, according to EXE02, an interviewee from BPKA, online systems have been implemented recently to minimise the risk of interference from the MPs in budget execution, but it is too early to tell whether these have successfully reduced the risk of corruption.

Since 2018, AF in Aceh has been called Pokok Pikiran DPRA. ${ }^{29}$ The change of name aims to reflect that these are programmes proposed by DPRA rather than a separate scheme. In 2018, the central government through the Ministry of Home Affairs' regulation on 2019 local budgets (Regulation No. 38/2018) posted new guidance regarding KUA-PPAS as well as Pokok Pikiran after the tough discussion on KUA-PPAS caused such political conflict between Aceh's executive and DPRA. It stated that, in the case the executive and DPRA cannot reach agreement over KUA-PPAS within 60 days of its submission, the Governor is to issue a decree implementing a budget based on the total amount of last year's budget. Further, all Pokok Pikiran programmes proposed by MPs need to be submitted one week before Musrenbang is held or the programmes proposed will not be allocated in the budget. According to LG04, "The enactment of this regulation [...] has caused members of parliament to speed up the budgeting process to avoid a Governor['s] decree".

The above discussions show that AF played a significant role in Aceh's budget delays. It caused the discussion over KUA-PPAS to take longer than the mandated timeline. However, as no penalties were imposed for this, it happened continuously in Aceh until 2018 (2014 excepted). Other reasons, such as poor budget planning by executives and that MPs tended to assume that delay was acceptable, were also raised by many interviewees. Surprisingly, despite the near-continuous late approval, all executives and MPs that I interviewed claimed

${ }^{29}$ In English, Pokok Pikiran means ideas. 
that everybody involved in the budgeting process realises the impacts of budget delays. It is to these impacts that I turn next.

\subsection{Late Budget Approval in Aceh: What are the Impacts on Budget Execution?}

The second research question in this study concerns the impacts of late budget approval. This question arises because Aceh receives a great amount of transfer funds each year from central government including the privilege of DOKA yet still has significant problems in economic growth, poverty, and unemployment rates, leading me to ask whether the oft-criticised budget delays play a part in causing these issues (see Chapter 2).

I found there were two major impacts of late budget approval to the budget execution in Aceh. First, the late approval of APBA caused late implementation of the programmes/projects planned. When APBA was not approved before 31 December, no new programmes/projects for the fiscal year could be implemented; only operational expenses such as electricity bills, salaries, and unfinished projects can be paid for, using any financing surplus from the prior fiscal year (SiLPA). ${ }^{30}$ This means that late APBA approval affects the procurement timeline, resulting in other consequences such as lower economic activities, lower level of budget realisation and lower quality of programmes executed.

As noted in Chapter 2, Aceh's economic activities depend heavily on government spending. ${ }^{31}$ Thus the delay in budget approval negatively affected many government programmes and activities. For example, when APBA was approved in March 2018, the executive had only approximately six months to implement a full year's projects as administrative processes and procurement activities take up to three months to complete. This resulted in lower economic activity in the province, creating other consequences such as unemployment, a major factor in Aceh's high poverty rate. The late implementation of government programmes and projects also resulted in lower budget realisation with the budget left in surplus by the end of the year, indicating that Aceh was ineffective and

\footnotetext{
30 SiLPA (Sisa Lebih Perhitungan Anggaran) is the surplus from the realisation between the revenue and expenditure within one reporting period. In Indonesia, SiLPA is used as one of the indicators of measuring budget efficiency (Muda \& Naibaho, 2018).

${ }^{31}$ Many of the interviewees also criticised the small percentage of industry in Aceh, noting that Aceh's economic condition is poor because of its dependency on government spending. As of 2015, Aceh had only 44 companies in the Large and Medium Industry classification (Badan Pusat Statistik Aceh, 2018a).
} 
inefficient in its use of financial resources. Further, because of the late approval, budget realisation occurred unevenly, dominated by the fourth quarter (see Table 4).

\begin{tabular}{|c|c|c|c|}
\hline Fiscal Year & Quarter & $\begin{array}{c}\text { Quarterly Budget } \\
\text { Realisation }\end{array}$ & $\begin{array}{c}\text { Cumulative } \\
\text { Percentage }\end{array}$ \\
\hline \multirow{4}{*}{2013} & I & $4.22 \%$ & $4.22 \%$ \\
\cline { 2 - 4 } & II & $14.50 \%$ & $18.72 \%$ \\
\cline { 2 - 4 } & III & $25.83 \%$ & $40.33 \%$ \\
\cline { 2 - 4 } & IV & $50.17 \%$ & $90.50 \%$ \\
\hline \multirow{4}{*}{2014} & I & $4.01 \%$ & $4.01 \%$ \\
\cline { 2 - 4 } & II & $17.43 \%$ & $21.44 \%$ \\
\cline { 2 - 4 } & III & $19.02 \%$ & $40.46 \%$ \\
\cline { 2 - 4 } & IV & $52.92 \%$ & $93.38 \%$ \\
\hline \multirow{4}{*}{2015} & I & $3.07 \%$ & $3.07 \%$ \\
\cline { 2 - 4 } & II & $20.48 \%$ & $23.55 \%$ \\
\cline { 2 - 4 } & III & $26.27 \%$ & $49.82 \%$ \\
\hline \multirow{4}{*}{2016} & IV & $45.36 \%$ & $95.18 \%$ \\
\cline { 2 - 4 } & I & $6.14 \%$ & $6.14 \%$ \\
\cline { 2 - 4 } & II & $26.32 \%$ & $32.46 \%$ \\
\cline { 2 - 4 } & III & $26.24 \%$ & $58.70 \%$ \\
\hline \multirow{4}{*}{2017} & IV & $35.44 \%$ & $94.14 \%$ \\
\cline { 2 - 4 } & I & $4.79 \%$ & $4.79 \%$ \\
\cline { 2 - 4 } & III & $26.63 \%$ & $31.42 \%$ \\
\cline { 2 - 4 } & IV & $46.26 \%$ & $58.05 \%$ \\
\hline \multirow{3}{*}{2018} & I & $58.05 \%$ & $92.77 \%$ \\
\cline { 2 - 4 } & II & $3.80 \%$ & $3.80 \%$ \\
\cline { 2 - 4 } & III & $18.53 \%$ & $22.33 \%$ \\
\cline { 2 - 4 } & IV & $28.86 \%$ & $80.94 \%$ \\
\hline & & $28.75 \%$ & \\
\hline
\end{tabular}

Table 4. Budget Realisation of Aceh Local Government for Fiscal Year 2013 to 2018 (BPKA Aceh Province, 2019)

Table 4 shows that APBA's realisation rate has historically been very low in the first quarter, due to its late approval, with most activity occurring in the third and fourth quarters as the spending gradually increases toward the end of the year. This pattern prompted me to investigate whether this pattern of budget execution affected the quality of the programmes/projects. S01 and EXE02 confirmed that it did:

That [high budget realisation in the last quarter] will likely affect the quality of all projects. Everything done in hurry results in a low-quality outcome. Either 
in a form of physical buildings or other services. When they are being rushed, the results will be obviously not satisfactory (S01).

Once it is started late, the implementation will be rushed. It all results in the quality of the service of the proposed programmes (EXE02).

However, while agreeing to the possibility of lower quality in the programmes and projects executed, another member of the executives, EXE03, presented an alternate view, that the high level of budget realisation at the end of the year could also occur because most contractors preferred reimbursement in the last quarter. Therefore, EXE03 argued, late approval did not have such a significant impact on quality because the executive had established monitoring and control systems. This statement suggests it may be possible that (at least some) executives or politicians in Aceh's public sector considered this pattern of budget realisation normal and acceptable, believing the monitoring and control system could resolve any quality issues. Such a perspective may, in my opinion, contribute to the delays of budget approval because these executives and/or MPs would not consider the issue of quality as an important reason to have APBA approved on time.

The second major impact of late APBA approval is late transfer of funds to regencies and municipalities. Just as Aceh's provincial government depend heavily on central government transfers, the regencies and municipalities within Aceh depend heavily on transfers from the provincial government. Consequently, when APBA was approved late, the regencies and municipalities would be unable to implement their programmes and projects regardless of whether their local budget has been approved on time by their related local parliament. The late transfer of funds then affected the regencies' and municipalities' economies, employment, and poverty rate in the same way as at the provincial level.

Figure 8 illustrates the consequences of late budget approval indicated by interviewees. It demonstrates that the late budget approval caused a 'domino effect', resulting in losses to society. 


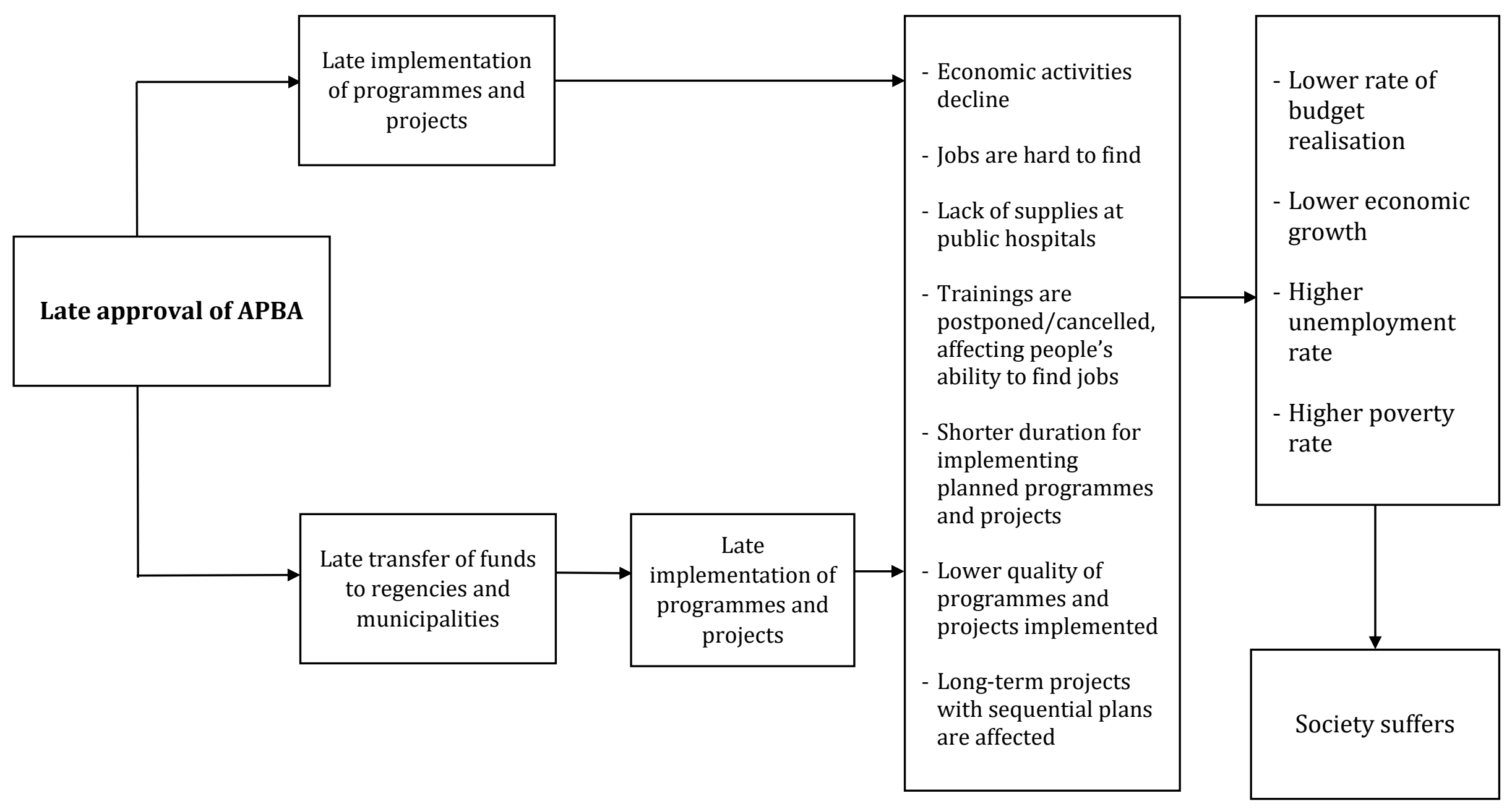

Figure 8. Consequences of Late Budget Approval in Aceh Province 
However, it is important to note that late APBA approval is not the sole cause of Aceh's problems in economic growth, employment, and poverty. According to S01,

It [achieving high economic growth and low employment and poverty rates] also depends on the programmes you set up. The programmes set up by the planning board [BAPPEDA].

This view was supported by all other scholar and MP participants, suggesting that Aceh has other problems in its budget planning, such as lack of database(s), lack of integration between government agencies, and the outflow of government spending going mostly to suppliers outside Aceh province due to a predominance of imported commodities and labour, to the detriment of local commodities and small-medium enterprises.

The above discussion showed some consequences of late budget approval which negatively impacted Acehnese economic and social welfare. These negative consequences are also problematic under conceptions of Islamic public budgeting which see government as being responsible for the care of the people (see Chapter 2). Therefore, in the next section I present my finding on the last research question in this study.

\subsection{As a Province Implementing Shari'a, Does Aceh's Budgetary Management Reflect Islamic Teachings?}

The third and final question in this study investigates Aceh's budgetary management through the perspective of Islamic teachings. I raised this question due to the implementation of Shari'a in Aceh and the significant influence of Islamic values and teachings in Acehnese identity and culture. I therefore investigate whether Islamic teachings on public budgeting are well-embedded in Aceh's government budgeting.

I assessed three major issues to address this research question. First, the lack of discipline around budgeting timeline by both the executive and DPRA. According to MS05, a Muslim scholar who previously worked in the executive, Islamic teachings should have encouraged government officials and politicians to be well-disciplined in public budgeting because they have been given amanah (trust) by Allah to manage public funds in the interest of the public. However, as described above, the political interaction between executives and DPRA as well as the DPRA's interests over AF reflected difficulties for Aceh's politicians and 
leaders of executive government in minimising conflict of interest in the budgeting process, thus causing budget delays with negative consequences. These issues indicate a poor implementation of Islamic teachings because, as Khan (2001, pp. 228-229) in his principles of an Islamic public expenditure framework says, "in matters of income transfers, the government should act speedily and avoid red tape" (Principle 12), "if there is a conflict between a private interest and [a] public interest, [the] public interest should prevail" (Principle 4) and "all expenditure should follow the criteria of the maslahah (interest) of the ummah (society)" (Principle 1). Therefore, with the issue of provincial budget delays, Aceh's government has failed to adhere to Islamic principles in regard to prioritising public interest over private interest and speedy transfers of funds.

Second, based on the discussion above, Aceh has also demonstrated poor resource allocation where the government institutions were not integrated in their planning scheme and tended to ignore the RPJM and RPJP as indicators in government planning and development. Moreover, several interviewees criticised the poor databases in government agencies, 'copy-paste' programmes, and the extravagance of Aceh's public expenditure ( $\mathrm{S02}$, SE04, EXE04, NG001, and LG03). In Khan's (2001) framework then, Aceh performed unsatisfactorily in incorporating Islamic budgeting principles into its budgeting process, especially for three principles in the framework which are: Principle 8 - public expenditure will follow the hierarchy of needs; and Principle 9 - there should be no waste or extravagance in the public expenditure.

Third, the issue of accountability is the most important aspect in an Islamic perspective on public budgeting. Islamic accountability holds two aspects of accountability to be uphold by leaders - accountability toward human beings and to the God Almighty, Allah (Khan, 2001). In the implementation of accountability toward human-beings, in Islam, one of the interviewees said that it is based on the saying of the Prophet Muhammad (peace be upon him), "al-muslimuna 'ala syurutihim", which means Muslims are bound by the agreements they have made collectively (MSE03). Thus, as long as all of the regulations set by the government do not violate the concept of halal (permitted) and haram (prohibited) as well as prioritise the maslahah of the ummah (public welfare), the government needs to adhere to those regulations to achieve good accountability toward human-beings. In Aceh's case, 
most interviewees agreed that Aceh still struggles on this issue - that is, accountability toward human-beings, especially on transparency. In Aceh people have little access to many budget documents such as KUA-PPAS. ${ }^{32}$ Perhaps this is due to the Indonesian regulation which requires only that the executive present a yearly report to the legislature and a tendency of government leaders and politicians to avoid public scrutiny since no regulation concerning government transparency has been passed in Aceh. This was suggested by S02 and LG03, saying that:

Accountability of Aceh's government can be regarded as 'poor' because the government tends to see accountability only as a requirement for presenting the yearly report. Accountability is not just about having an accountable report, but also about the 'meaning' of those numbers in the report. Now, if we ask the government officials and politicians, "what do these numbers [in the report] mean?" They will say, "we don't know, these numbers are prepared by the accounting department, and that is how it should be" (S02).

[We're still having issues in transparency], KUA-PPAS should be open and accessible for the public to see. If this is concealed - for example, a closed meeting, then there is no transparency, [...] then there will be collusion. Aceh has been one province that still does not pass a public transparency law (LG03).

Regarding accountability toward Allah, MS01 noted:

Well... the accountability to Allah dimension is a faith dimension. It is actually a spiritual dimension. So, if someone has a strong faith, then s/he will do everything better as it supposed to be. Her/his spiritual dimension is simply the thing that triggers her/him to do better.

\footnotetext{
32 People in Aceh also cannot follow the budgeting process after Musrenbang is held. The only document that is accessible is the approved APBA. Therefore, all political process and decision-making made between Musrenbang and APBA approval remains private.
} 
The statement suggests that faith in Allah should have ensured that government officials and politicians maintain a high standard of conduct: no corruption or collusion, budget discipline, high level of transparency, addressing social issues properly, and so forth. However, it appears that accountability to Allah carried little influence in the budgetary management as Aceh still faces the problems described above. Thus, all the Muslim scholars interviewed in this study hoped for a more comprehensive implementation of Islamic values and perspective in Aceh's Shari'a law. A minority of interviewees suggested that the dependency of local budgeting in Indonesia on the central government regulation makes it impossible for Aceh to implement an Islamic budgeting system. However, I regard such a statement as inappropriate, since as illustrated through Khan's (2001) framework of Islamic public expenditure and Naqvi et al.'s (2011) model of good governance (see Chapter 2), Islamic principles and values in the public budgeting do not regulate the techniques of government budgeting. Rather, it consists of principles and values to which any system established can be adjusted to conform (see Chapter 2). Indeed, all scholar participants in Islamic studies noted that the main challenge to implement Shari'a to a greater degree in Aceh is to deal with the Acehnese 'mindset' about Islam, in order to see Islamic values and perspectives in a wider context. MSE04, for example, said:

[...] because if we are talking about Islam here [in Aceh], people rarely associate Islamic teachings with how economics or politics should be conducted. People are [just] talking about worshipping activities, about gambling for instance. Even for gambling, they tend to focus on the gamblers but not the larger picture, for example the gambling activities in investment or financial transactions. This is the challenge, about the mindset of our people. For most of them, Islam is only about worship.

This statement shows that most Acehnese still perceive Shari'a as only about regulating a few aspects of life such as worship, criminal law, and clothing. Meanwhile, the conduct of officials, especially in public budgeting, is rarely overseen by any of Aceh's Shari'a agencies or the wider society. Perhaps, this is because the Governing of Aceh Act does not clearly define the extent of Shari'a implementation. The Act only mentions that the government is 
expected to ensure a kaffah (comprehensive) implementation of Shari'a law in Aceh. However, neither the extent of kaffah nor detailed description of Islamic values and principles expected to be implemented are well-explained in the Act, leaving unanswered how government activities, including budgeting, should incorporate Shari'a. This was alluded to by EXE05 who works at an Islamic Shari'a Agency:

When we're talking about the Islamic Shari'a Agency in Aceh, compared to other agencies, it is actually the most recent one. [It] isn't equipped with its technical plan or grand design yet, so we do not have indicators or guidelines to assess. We still do not have a blueprint yet (EXE05).

Further, a divide between so-called 'Islamic' agencies, such as the Islamic Shari'a Agency and Islamic Education Agency, and other agencies, such as the Education Agency and Financial Agency, was noticeable. I asked how the Islamic Education Agency differed from the Education Agency as they seemed to naturally serve the same purpose. EXE05's answer to this question was:

Well, if you only ask about the differences, it is clear to see that the Islamic Education Agency focuses on Dayah while the Education Agency focuses on other type of schools and education providers.

Without diminishing the concerns that led to the establishment of the Islamic Education Agency, I suggest that having two different government agencies with such similar purposes and tasks could lead to inefficiency and ineffectiveness of planning and budgeting due to the overlaps and additional bureaucracy. Moreover, according to EXE05 and information from an informal conversation with a government official, there was little integration or communication between the Shari'a agencies and other agencies in the planning process.

I also found another element in the Islamic budgeting 'mindset' in Aceh - that executives and MPs mostly perceive only programmes planned and executed by Shari'a agencies as 'Islamic'. This was implied by how these interviewees responded my question on whether Islamic values and principles were embedded in Aceh's budgeting. Instead of relating this question to the process of budgeting, their immediate responses went to the 
argument that higher amounts of funding had been allocated to the 'Shari'a' agencies. This may indicate that the six Shari'a agencies are treated as a symbol of Shari'a implementation in Aceh; as MSE04 argued:

When the Shari'a is institutionalised, the Shari'a roles become understated. So, it gives an impression that the Shari'a is just an institution.

This means that the separation of Shari'a and non-Shari'a agencies imply that there are only certain areas that are considered 'Islamic'. MS02 then further suggested that, if Aceh wanted to implement Shari'a law comprehensively, there would be no need of Shari'a agencies. Instead, all government agencies would perceive and embed Islamic values and principles in their planning. However, MSE03 who is also an advisor at BAPPEDA, then indicated that some embedding was occurring;

[In] BAPPEDA, currently, there is an improvement on how Islamic values are being perceived. It has started to merge in the planning. So, right now, we [BAPPEDA] understand that we do not need to allocate more funds for Shari'a agencies in order to be Islamic. However, the problem here is that the planning and budget are later discussed and approved by the DPRA where the process turns to be political [emphasis added].

This led me to ask whether such political process in budgeting is acceptable within Islam. MS01 answered:

In Islam, politics is viewed as something positive. For example, in the idea of how politics can be the way to benefit the people. In other words, how politics can be run to distribute the budget to people efficiently and effectively. This kind of politics is the one which is emphasised in Islam. But when politics is used to go against that very idea, or when there are disputes between executives and legislature, Islam is against it. Islamic values contradict with politics that sacrifice public interest. 
The other Muslim scholar participants agreed with this statement, emphasising that conflict between politics and Islam can arise from how well one uses his/her political power for the benefit of the people, not on the nature of politics itself.

Based on the above discussion, I argue that Islamic values and principles were not wellembedded in Aceh's budgetary management as Aceh provincial government is yet to achieve good performance in the dimension of accountability toward human beings because of its budgetary management problems. Perhaps the key point here is to understand the concept of accountability toward Allah beyond religious rituals and symbols. Understanding the concept of accountability toward Allah through this holistic perspective allows Muslims to regard humans as Khalifah (stewards) in all aspects of human activities, including governmental activities (see Chapter 2). According to all the Muslims scholars participating in this study, there are four characteristics of khalifah taught by the Prophet Muhammad (peace be upon him): siddiq (truthful), tabligh (transparent), amanah (trustworthy), and fathanah (intelligent). These qualities are crucial to achieving good accountability in the world and the hereafter. However, these Muslims scholars then suggested that these characteristics are not well-embedded in how the government officials and politicians conduct public budgeting. This may be because the government's decision-making in budgeting is often the result of compromises aimed at resolving conflicts of interest between the executives and the MPs rather than the maslahah of the ummah. Further, transparency in the province also remains problematic and too often, government officials, politicians, and society leaders made their budgeting decisions based on desires rather than needs, as indicated by MS01, MS02, and MS05. Therefore, as the ideas of fairness, justice, and transparency are crucial in Islamic public governance (Naqvi et al., 2011), I argued that Aceh province is yet to implement satisfactory Islamic good governance and accountability due to problems in its budgetary management as described above.

As outlined in Chapter 2, in Islamic teachings, the conduct of a government in budgeting process need represent the high standard of conduct expected of those motivated by the 'fear' of Allah. In Aceh's case, although this kind of religious motivation arguably needs to come from one's own heart and mind, ignoring Islamic principles and values in the budgeting process seems inappropriate while at the same time claiming that Aceh is an Islamic 
province due to the enactment of Shari'a. This suggests that improvements in the implementation of Shari'a remain necessary in Aceh if it is to represent the concept of Islam as Rahmatan lil Alamin (a blessing for the whole world and all creation, including human beings, animals, and the nature) (Herijanto, 2017).

\subsection{Summary}

In this chapter, I presented the findings from the research questions posed by this study. I began by outlining the findings for the first research question - the reasons for late budget approval in Aceh. These delays in Aceh were caused by two major reasons. First, the political interaction between the executive and DPRA in the budgeting process, resulting from clashes of priorities, caused long and difficult negotiations. Both institutions were also found to experience miscommunication, resulting in further delays to budget approval. Second, budget delays were caused by the interests of MPs in the AF scheme and their tendency to propose programmes after KUA-PPAS was submitted. This creates difficulties for executives in adjusting the budget to fit with their priorities and the budget ceiling, causing further delays. MPs also often ignored some technical considerations in proposing their programmes, such as appropriate authority and eligibility of various programmes.

Next, I presented my findings on the second research question: what are the impacts of late budget approval to the budget execution in Aceh? Aceh's economic activities depend heavily on government spending, so budget approval impacts significantly on Acehnese welfare. I found that the delays in the budget process, particularly the approval, had negative effects by delaying the implementation of programmes/projects and transfer of funds to regencies and municipalities. These delays caused a domino effect where lower economic activity occurred, causing unemployment and leading to increased poverty. The delays also affected the activities of government institutions. This in turn causes a poorer quality of public goods and service delivery due to less time for implementing the government's agenda.

Finally, I addressed the third research question - the implementation of Islamic principles and values in Aceh's budgetary management. Here, I argued that, although Aceh has implemented Shari'a, budget indiscipline, corruption, and problems in transparency indicate that Islamic values and principles are not well-embedded in Aceh's budgeting 
process. This was potentially caused by a claimed 'narrow' perspective, which instead of perceiving Shari'a as a set of pervasive values and principles, saw it mainly in the context of certain areas such as worship activities and criminal law. As a result, executives and MPs tended to see 'Islamic' budgeting as simply as allocating more to Shari'a agencies.

The arguments made by participants in this chapter displayed justifications related to the budget approval, its consequences, and the implementation of Islamic principle budgeting in Aceh. Thus, as my study engages in analysing these issues through accountability lens, in the next chapter I present my theoretical analysis of the findings discussed above. 


\section{CHAPTER 6 THEORETICAL ANALYSIS}

In this chapter, I present my theoretical analysis of the findings outlined in Chapter 5 through the lenses of accountability theory, employing the SoW framework of B\&T (1999) to analyse the justifications public sector actors. I start this chapter by presenting my analysis of the justifications expressed for the late budget approval in Aceh, based on interviewees' justifications toward the phenomena, analysed using the SoW framework. After that, the chapter concludes with a summary of these analyses.

\subsection{Who Is/Are to Blame for Late Budget Approval in Aceh? A Sociology of Worth Analysis}

As outlined in Chapter 3, the idea of answerability in public sector relates to the responsibility and relationship dimensions of public accountability, noting the obligation to provide information to related stakeholders. Thus, for Aceh's case, understanding relationships formed through the budgeting process is essential to analysing the answerability dimension of accountability in regard to budgetary management (see Figure 2). For Aceh's case of late budget approval, the relationships between executives and MPs play the most significant part. Therefore, the findings of this study, presented in Chapter 5 , show the clashes of argument between the executive and DPRA over the reasons of this issue. Table 5 overleaf summarises the arguments of executives and MPs interviewed: 


\begin{tabular}{|c|c|}
\hline EXECUTIVES & MPs \\
\hline $\begin{array}{l}\text { - DPRA tended to postpone budget } \\
\text { discussion meetings, especially for KUA- } \\
\text { PPAS. } \\
\text { - TAPA always handed in the KUA-PPAS } \\
\text { document on time because there is a } \\
\text { timeline that needs to be kept. }\end{array}$ & $\begin{array}{l}\text { - DPRA tended to postpone the meetings } \\
\text { for APBA due to other commitments. } \\
\text { - TAPA often submitted KUA-PPAS late. }\end{array}$ \\
\hline $\begin{array}{l}\text { - DPRA did not fully understand the } \\
\text { technicalities of the budgeting process, } \\
\text { prioritising their political views in the } \\
\text { resource allocation process rather than } \\
\text { accounting and economic approaches. }\end{array}$ & $\begin{array}{l}\text { - Executives did not prepare the budget } \\
\text { according to RPJM and RPJP. } \\
\text { - DPRA asked TAPA to revise the prepared } \\
\text { KUA-PPAS, but they gave little attention } \\
\text { to these requests. }\end{array}$ \\
\hline $\begin{array}{l}\text { - DPRA tended to focus on the allocation of } \\
\text { AF, leading to long discussions over KUA- } \\
\text { PPAS } \\
\text { - DPRA tended to propose programmes } \\
\text { outside provincial government } \\
\text { jurisdiction which oftentimes are not } \\
\text { aligned with the Governor's vision and } \\
\text { mission }\end{array}$ & $\begin{array}{l}\text { - Many complaints were raised by the } \\
\text { public, saying that their regions and } \\
\text { villages were not prioritised by the } \\
\text { government. So, DPRA, as the } \\
\text { representatives of the people, wanted the } \\
\text { development process in Aceh } \\
\text { implemented fairly. } \\
\text { - The executives usually ignore people's } \\
\text { aspirations raised as by the MPs. }\end{array}$ \\
\hline
\end{tabular}

\section{Table 5. Summary of Arguments by Executives and DPRA}

Table 5 highlights a pattern in the arguments executives and MPs used to justify late approval of APBA. First, the executives' arguments demonstrate concerns over the mandated budget timeline and technicalities of resource allocation, indicating the importance to them of adhering to regulations imposed by the Ministry of Home Affairs. This may be because the authority of the executive over local resource allocation and budgeting is delegated from central government (see Figure 1 and 2). Thus, executives perhaps perceive that they have obligations toward such central government regulations. Meanwhile, MPs have less concern for the budget timeline as their authority derives from being directly elected by the people, rather than from being appointed by central government. Thus, MPs' reasons for the budget delays seem more political as they emphasise MPs' role as representatives of people; 
concerns over their constituents often appeared in their answers during interviews. Within SoW, "the one who criticises other persons must produce justifications in order to support their criticisms just as the person who is the target of the criticisms must justify his or her actions in order to defend his or her own cause" (B\&T, 1999, p. 360) and the arguments offered by both executives and MPs demonstrate just this when their arguments showed justifications for late budget approval.

As outlined in Chapter 3, two of B\&T's (1999) orders of worth, namely civic worth and domestic worth, are the most relevant to analysing the justifications of Aceh's late budget approval. In civic worth, the subjects are elected officials or representatives of the public (B\&T, 1999). This order's state of worthiness is defined by civic duty, meaning that this is a world where the public interest constitutes the ultimate worth (B\&T, 1999, 2006; Annisette \& Richardson, 2011). Therefore, justifications given within this order will focus on collective interest. I found that MPs interviewed often addressed the public interest in their justifications, emphasising that the delays to budget approval were due to the public interest being addressed poorly in the proposed KUA-PPAS.

The justifications of executives, and a few scholars who had previously worked in the executive, expressed adherence to central government regulations, a focus on delivering satisfactory public goods and services and the use of accounting and economic approaches in allocating financial resources, implying that hierarchy of trust as well as the public interest was important in public budgeting. This indicates that the executives (subjects) were classified into multiple orders of worth, consistent with Le Maître's (2006) findings that government can also be classified in the civic and domestic order at the same time. For example, EXE01 implied that complying with the budget timeline imposed by regulation was a greater obligation than completeness:

When we have to propose KUA-PPAS, then we propose it at the right time although it might not be perfectly well-prepared.

Other executive participants, when asked about late budget approval and AF, indicated the presence of a hierarchy of trust, a characteristic of domestic worth, in their references to a number of Ministry of Home Affairs' regulations. Executives, as public servants, might also 
be expected to offer civic worth justifications and my findings support this: when asked about the impacts of late budget approval, many expressed concerns about society suffering (see Chapter 5), a public interest criterion of worthiness. Furthermore, the direct election of the Governor and Vice-Governor places them within the civic worth realm, although, with their power being delegated by the President, they can also be considered simultaneously as subjects of domestic worth.

Despite prior studies suggesting that public officials are classified only in the civic and/or domestic orders (B\&T, 1999; Le Maître, 2006), I found indications that the executive may also be classified into a third order of worth, the industrial order in which the subjects are professionals, experts, and specialists, embracing efficiency and effectiveness as the supreme worth. For example, AIE03 said:

We [the executive] usually used the economic approach in the preparation. We calculated the budget input and output, and we even analysed the cost benefit. Every single thing was calculated carefully.

The above statement illustrates that measurements and concerns toward effectiveness and efficiency of budget are present in the executive's justifications on budgeting process. Further, as the statement was mentioned by a scholar who works as a government advisor, it shows that professionals and experts were a part of the executive and involved in budget planning. However, it may also be possible that these criteria of industrial order appeared as a result of hierarchy of trust, a criterion of domestic order. This is because the justifications expressed by the executives in regard to measurements may be motivated by the regulations set by Ministry of Home Affairs on implementing performance-based budgeting for government budgeting; that is, Government Regulation No.20/2004 on Government Planning. Also, since its public sector reforms, the Indonesian central government, through decentralisation, has encouraged local governments to conduct and produce an effective and efficient budget (see Chapter 2). Thus, while B\&T distinguish civic, domestic and industrial orders as separate orders of worth, the above scenario shows that in Aceh's case of budgetary management, classifying public sector actors to particular order of worth(s) is difficult, because they often combine multiple criteria of orders in their justifications. 
Budgets act as a tool for controlling and measuring performance, so in a SoW framework they are considered as objects of the industrial order of worth, where efficiency and effectiveness indicate its state of worthiness. While good governance promotes efficiency and effectiveness in government budgeting, the justifications offered by executives and MPs showed that, in this context, APBA is seen not only as an accounting tool but also as a symbol for due process and legality and a demonstration of moral reasoning, good manners, and etiquette. Budget discussions involved concepts of public interest, adherence to regulations and measurements and the consequences of late budget approval, illustrating a domino effect where it can potentially lead to the violation of regulations and harm economic and social well-being, demonstrating that objects can also inhabit multiple orders at the same time. This finding is consistent with Annisette and Richardson (2011, p. 235), who say that "accounting data itself can become objectified in several worlds, [...] outside the realm of the industrial".

With regards to responsibility for Aceh's late budget approval, one might easily conclude that both the executive and the DPRA are culpable, or even directly pinpoint one of them as the culprit. My findings show that both were aware of the consequences of late budget approval yet were unwilling to resolve the problem until the central government imposed new regulations (see Chapter 5). Nevertheless, I argue that it is difficult to place blame on only one or two actors or institutions. Whilst the budgeting process and decision in Aceh are managed mainly by TAPA and DPRA, the bottom-up process involving public and society leaders in the process adds to budget indiscipline:

Our people mostly do not understand the budgeting process, especially its timeline and technicalities. What they know is that they would like [their] MPs to fund their programmes or provide grants for their villages. [...] most of the time, they propose programmes to members of DPRA when KUA-PPAS has been submitted (LG03).

Whilst many MPs contributed to this indiscipline by conducting their consultation process asking for society leaders' programme after KUA-PPAS had been submitted (LG03), I argue that lack of understanding of society leaders of the budgeting process and timeline may have 
also contributed to the budget indiscipline in Aceh through motivating MPs to pressure the executive to allocate 'aspiration' programmes after the budget ceiling and budget draft were prepared.

Whilst most participants in this study referred to resolving conflict of interest and political gap to avoid future budget delays, LG04 provided an interesting response when asked about the solution for budget delays:

Actually, our belief [in Allah] is the solution for all of these [budgeting] problems. It is the simplest solution. All of us [officials and politicians] are under oath in here, an oath to Allah, when we were appointed. So, I always say, "Let us focus on what we need to focus on [the public interest], we only live temporarily in this world". But it is hard to get on their mind, because it needs to come from their own internal motivation.

Such statement indicates that in a devout Muslim society, belief in Allah constitutes the most supreme worth, driving Muslims to behave accordingly, based on Shari'a. This is why Khan (2001) and Naqvi et al. (2011) emphasise the importance of accountability to Allah in their framework and model. Similar views were expressed by all the Muslim scholar participants of this study. Such a perspective is classified SoW under the world of inspiration as worthiness is defined "upon the attainment of state of grace" (B\&T, 1999, p. 370). However, to my knowledge, no prior study has indicated the presence of the inspired order in regards to government accountability, with Dormer (2018), in his study about accountability in New Zealand (a non-Muslim society), finding that no discussion of accountability referred to this order of worth. In this study therefore, I suggest that, in a devout Muslim society, an aspect of holiness is present, the object of world of inspiration, along with criteria of civic, domestic, and industrial orders, indicating that the public budgeting process is (or should be) a sacred activity for Muslims. Therefore, through this study I found that in Aceh's budgetary management, these orders (i.e. civic, domestic, industrial, inspiration) occurred so often together that they are difficult to separate, except analytically.

In Chapter 5, I explained how tough discussions over KUA-PPAS contributed to Aceh's late budget approval. Those discussions involved clashes of interests and argument between 
executives and MPs, which are considered disputes between the different orders of worth in SoW. Although late, most of the time Aceh achieved budget approval through compromise, consistent with B\&T (2006) who note that disputes involving multiple orders of worth frequently resolve this way. In the next sub-section, then, I turn to the compromises achieved.

\subsubsection{Aceh's budget approval: an art of compromising}

So, there are compromises in here [for the parties]. This means, we [MPs] wouldn't care less on what's inside the budget prepared by the executives, be it extravagant or whatever they put in there, as long as the executives allocate the programmes proposed by MPs and do not interfere with it, the MPs will not interfere in the executive government's programmes in the budget (LG03).

This statement emphasises compromise as the key method of resolving conflicts between TAPA and DPRA in the discussions over KUA-PPAS, leading them to an agreement on APBA approval, however late. In political organisations, such acts - compromise arrangements - are common when the clashing parties try to reconcile and have their interests allocated, as argued by Annisette and Richardson (2011): "coordination is therefore achieved through an agreement on a common good which does not privilege any of the orders of worth in conflict". In SoW, these compromise arrangements allow different orders of worth to co-exist (B\&T, 1999).

In Aceh's public sector, compromise arrangements have become prevalent practices in budget discussions, especially in allocating AF:

[AF] has been used as DPRA's 'bargaining power' which means that DPRA will speed up the approval of budget if the executives provide no questions on the [MPs'] proposed programmes (NGO01).

Compromises leave no party completely happy and no order of worth completely satisfied however, as MSE03 noted, '[...] we ended up with compromises which can disrupt the wellprepared budget itself'. This implied that, for the executive, such compromises are viewed as 
a threat to an effective and efficient budget as it could potentially leading to inequities in public provision of goods and services. Consequently, such compromises may possibly reduce the province's economic and social well-being.

The late budget approval in Aceh illustrates that in a public-sector setting, budgeting processes and resource allocation are driven at least as much by political forces as by technocratic imperatives, supporting Farhan's (2018) findings. In Aceh, APBA became an object of compromises between TAPA and DPRA because of different views on what public interest meant and how this should be made operational through APBA, as outlined in Chapter 5. Thus, I argue, budget approval in Aceh operated more as an art of compromising and negotiating than as segregation of duties in which TAPA prepared the budget, DPRA reviewed and approved it by passing regional regulation, and government agencies executed the budgeted programmes for the benefits of society.

Whilst B\&T (1999) do not explore the possibility of compromise arrangements to cause accountability problems, I suggest that such arrangements, when applied to budget discussions in a less transparent government setting, may potentially cause problems in this dimension, since the public, as public sector stakeholder, is entitled to political information, including what happens inside the budgeting process. Although transparency forms only one element of good governance (see Chapter 2), the responsibility to provide information is a crucial aspect of achieving good accountability, indicating that transparency is important for accountability. It is through transparency that stakeholders become knowledgeable of political information, allowing them to conduct public monitoring, ensuring that the government bases their decision-making, including budget decisions, on public interest and economic approaches to achieve efficiency and effectiveness. Consequently, in an environment where no transparency regulations are implemented, government accountability to the public regarding budget decisions becomes questionable and problematic regardless of the justifications argued by the government leaders and politicians.

In Aceh, transparency is considered poor, as argued by LG03:

Until now, Aceh is one of the provinces which does not have regional 
regulation concerning transparency. I have fought for it since 2014, but not yet succeeded. This is because many of us [MPs in DPRA] and the executives still afraid of being open, so it means there are things that they want to hide from the public.

Further, the budgeting arrangements after Musrenbang are also conducted away from the public; even documents such as KUA-PPAS were not easily accessible for the public, as argued by LG03:

Good transparency allows the public to monitor [both MPs and executives]. So, government websites should have provided the information, KUA-PPAS for example; it should have been published to the public. [...] budget documents are treated as if it is exclusive for the government. Therefore, if they [public] are left in the dark, there will be compromises, which will not provide any benefits for the society. So, this [transparency law] is what I keep fighting for since 2014, but it's hard to fight alone.

Aceh's problem with transparency is significant. During data collection, I had difficulty retrieving documents such as detailed budgets prior to the 2010 fiscal year and budget meetings before 2018. This was not only because the documents were not published but also because they had not been archived properly. To date, only the approved budget is published on the government website, and the budget implementation documents of executive agencies in Aceh remain difficult to access. Perhaps, this is because the executive government and DPRA generally perceive accountability purely an administrative process where the financial report should be prepared, audited, and presented in front of the yearly parliamentary session on financial performance, as argued by S02 in Chapter 5. Thus, since MPs are generally perceived as the representatives of the people, who should critically assess the executive's accountability, I asked a follow-up question to NGO01 on what usually asked in the budgetary parliamentary session by the MPs and what are the responses given 
by the executive government. ${ }^{33}$

In Aceh, they [executives and DPRA] tend to think only about how to spend the money available. That is the logic and frame used by Aceh's local government, be it in the planning, budget approval, and budget implementation. [...] so the budget realisation rate is the most important for them, not how the budget was utilised [...] this is why it is really rare to see MPs express critical arguments toward the executives' performance [in the parliamentary session] based on an economic approach. Even if they are being critical, it is only on certain things like local flag, local hymn, etc. Only eight to 12 of them have an ability to review the report 'properly' (NGO01).

This was noticeable in the answers from the MPs interviewed regarding their views on the accountability of Aceh's executive government, saying that the MPs had many other tasks and commitments and there were external and internal auditors who have been assigned to view such documents with economic and financial approaches. While LG03 argued that MPs have been critical toward the executives in the parliamentary sessions as DPRA did establish a special committee to monitor the efficiency of government projects, LG04 implied that the criticisms expressed during parliamentary sessions were a formality. In other words, those criticisms were often expressed just because of the rules in the parliamentary session that requires the MPs to show their thoughts on the report. However, the answers from the executives then tended to remain just as 'answers' with little follow up. I suggest that this may be due to the involvement of the MPs in the budget allocation through AF. As described in Chapter 5, MPs were known to interfere the budget implementation, especially in programmes they proposed through AF scheme. Therefore, being too critical could cause problems for themselves.

The above discussion shows that Aceh provincial government's performance in its accountability to the public remains disappointing, with the public remaining unaware of the compromise arrangements in the budgeting process post-Musrenbang. As a result, the

33 This question was inspired by B\&T's 'dual imperative' of justification, where both criticiser and criticised need to provide justifications. 
Acehnese public has limited platforms to monitor and critique government decisions on budgeting. I argue therefore that, linking Aceh's case to the answerability dimension of accountability (see Chapter 3), Aceh's provincial government is yet to deliver a satisfactory performance on accountability as the government still struggles with the responsibility that is, its duty to provide information - and relationship - greater participation of public dimensions of accountability.

\subsection{Summary}

In this chapter, I presented my analysis of the findings in Chapter 5 through the lens of accountability. First, I laid out my analysis of the justifications argued by the executive and MPs using B\&T's (1999) SoW framework, showing how different orders of worth are involved in Aceh's budgetary management. Despite a government being initially classified as civic and/or domestic orders, the justifications expressed by participants in this study also suggested certain criteria of industrial due to concerns toward effectiveness and efficiency of budget.

Whilst no prior study has linked the inspired order of worth to budgeting and accountability, justifications of participants (Muslim scholars, MSE03, and LG04) in this study showed that when budgeting and accountability are seen through an Islamic perspective, holiness, an object of inspired order, is present. This is because in the Islamic teachings, governmental activities, including budgeting, are considered sacred as Muslims will be held accountable to Allah in the hereafter. Therefore, I argued that when applied to Aceh's budgetary management case, it is difficult to separate the orders of worth involved except analytically.

Then, I continued to analyse how the justifications offered turned into disputes which were then resolved by compromise. I argued that Aceh's problems with late budget approval were consistent with B\&T's (1999) theoretical exposition of disputes and compromise arrangements as the clashes of multiple interests of different stakeholders in Aceh's budgeting process led to the exchange of blame and disagreements, later settled by compromise arrangements between TAPA and DPRA. However, due to poor transparency in the province, I argued that such arrangements may cause further problems for government accountability and harm the rights of society to economic and social well-being because the 
public is unable to monitor governmental decision-making and has limited platforms for asking questions or expressing criticisms.

Having laid out my theoretical analysis of this study's findings, in the next and final chapter I offer some conclusions and suggestions for further research. 


\section{CHAPTER 7 CONCLUSIONS}

This study aimed to investigate problems of Aceh's budgetary management, specifically late budget approval, its impacts on budget execution, and the implementation of Islamic principles and values in budgeting process. This study was conducted in a qualitative approach, as a case-based study with an interpretive data analysis. To address the research questions developed in Chapter 2, I carried out 19 interviews with scholars, executives, MPs, and the coordinator of a corruption watchdog. I also gathered a wide range of written materials, including annual budget documents and internal records of official reports on parliamentary sessions, to allow a deeper understanding of the investigated phenomena. This final chapter summarises key findings before discussing research contributions and limitations, closing with suggestions for future research and autobiographical reflection.

\subsection{Summary of Key Findings}

RQ1: What are the reasons behind the late budget approval in Aceh?

Late budget approval has occurred continuously in Aceh until 2018, except for the fiscal year 2014. Based on my analysis, this was driven by the political dynamics between the executive government and DPRA, especially in the discussion of KUA-PPAS. Thus, two major themes emerged from this study.

First, I identified a gap in political interaction between the executive government and DPRA. The executive and DPRA evidenced different perspectives on the idea of public interest, indicating a gap in their communications as both institutions were always likely to defend their own power in the budgeting process. I contend that this arises because the heads of executive government, the Governor and Vice-Governor, who are directly elected, have priorities during their term in office. Meanwhile, MPs in DPRA - also elected directly hold themselves as representatives of their constituents, arguing that their constituents' welfare was one of the most important considerations in APBA allocations. The MPs' and executives' responses regarding reasons for budget delays showed an exchange of blame and criticism. Most MPs interviewed argued that the KUA-PPAS proposed were not in accordance to RPJM and RPJP and that many of the programmes were simply 'copy-paste' from the 
previous years' budget and work plan. Furthermore, they argued that many of people's aspirations were not well-reflected in the proposed KUA-PPAS. In contrast, the executives claimed that it was the MPs who postponed discussion on KUA-PPAS. One MP, however, agreed with the executives, arguing that lateness had become habitual, suggesting that the budget timeline was not a DPRA top priority and perhaps that lateness has been considered normal and acceptable by the MPs.

A second reason for late budget approval was MPs' interests in AF. The political interest in AF was significant to how resources were allocated. AF has attracted MPs' interests to realise their constituents' aspirations through local budgets. Whilst the idea behind AF was to accommodate people's complaints and disappointments over the executive government's performance in maximising public's welfare, the scheme has instead arguably served MPs' own political interests (e.g. gaining more votes in elections and corruption). Nevertheless, the interest of MPs in AF created delays to the budget timeline when they proposed programmes after KUA-PPAS was submitted by TAPA, since the executive government found it difficult to adjust the well-advanced KUA-PPAS and agencies' RKA in response, and when many of the programmes proposed were outside provincial authority and in the type of grants and social aids which have different sets of regulations in the budgeting process. One reason for this was that MPs often underestimated the APBA timeline, and so did not prioritise gathering people's aspirations before the preparation of KUA-PPAS. Similarly, society leaders' poor understanding of the budgeting process added further delays by imposing their agenda on MPs without regard to the budget timeline. To avoid losing trust from their constituents, MPs could not refuse these demands and so continued to propose new programmes after KUA-PPS was prepared. This added to the pressure on the executive, provoking further heated debate. As a result, these disputes over the allocation of money to programmes through AF led to further delays in budget approval.

RQ2: What are the impacts, if any, of late budget approval to the budget execution?

The issue of late budget approval in Aceh has resulted in much criticism from scholars and corruption watchdogs because it could affect Acehnese economic and social well-being negatively. In this study, I found two major impacts of budget delays to the budget execution 
in Aceh. The first impact is that of delays causing a late implementation of the government's agenda. This negatively affected the procurement timeline, resulting in the government having less time to implement programmes and leading to a budget surplus at the end of the fiscal year. Then, the delays also resulted in most government activity occurring in the last two quarters of the fiscal year. Such a pattern of budget execution leads to the possibility of lower quality in the programmes and projects implemented from the attempts to hasten the process and achieve a higher budget utilisation rate. Further, as Aceh depends heavily on government spending, the interviewees in this study perceived that the late implementation of projects and programmes negatively impacted Aceh's economic activities with fewer people able to find jobs. Therefore, when the delays continuously occurred, it was seen to contribute to the cause of a lower rate of economic growth, higher level of unemployment, and higher poverty rate in the province.

The second major impact of the budget delays is the late transfer of funds to regencies and municipalities, including the transfer of DOKA. As outlined in Chapter 5, Aceh's regencies and municipalities depend heavily on provincial government transfers. Consequently, budget delays at provincial level negatively affect regencies' and municipalities' budget utilisation rates, economy levels, employment rates, and poverty rates. Nevertheless, it is important to recognise that Aceh's problems with economic growth, employment, and poverty are not solely from late budget approval as the province showed other problems in its budgetary management such as lack of databases, lack of integration between government agencies, and government spending mostly being paid outside Aceh.

RQ3: Does the budgetary management in Aceh local government represent a good implementation of Islamic principles and values?

a. If yes, how so?

b. If not, why not?

In addressing this research question, I assessed Aceh's budgetary management through the principles of public budgeting in Khan's (2001) framework and the Islamic good governance model developed by Naqvi et al. (2011). The first issue assessed was the indiscipline in the budgeting timeline. As outlined in Chapter 2, Principles 4 and 12 state that 
public budgeting should prioritise public interest over private interest and embrace speedy income transfers. Thus, for these aspects, Aceh showed unsatisfactory performance because of its budget delays caused, at least in part, by conflicting interests between the executive government and DPRA.

Against the other relevant principles of Khan's framework (principle 8 and 9), I found that Aceh struggled in its resource allocation. Government agencies demonstrated poor integration in their planning scheme, had poor demographic databases and data on past performances, and tended to ignore RPJM and RPJP as indicators in their planning. Several interviewees criticised the government's extravagance in public expenditure and the 'copypaste' government agenda. Therefore, I argue that these problems would create difficulties for Aceh provincial government to satisfy these principles of Khan's (2001) framework.

Lastly, I assessed problems in Aceh's budgetary management through the ideas of accountability to human-beings and accountability to Allah. These two dimensions of Islamic accountability need to be performed together as one is not achievable without the other, since government officials and politicians have been given amanah (trust) by Allah and the people to manage public funds. Further, in Islamic belief, Muslims will be held accountable for their conduct not only in the physical realm but also in the hereafter. Therefore, according to Khan's (2001) framework of Islamic budgeting and the model of Islamic good governance by Naqvi et al. (2011), a government should have an unbiased system of accountability as all government officials and politicians need to be accountable to the people and to Allah for each penny spent or withheld. In Chapter 6, I found that Aceh's provincial government is yet to implement a satisfactory accountability system based on Islamic teachings. In this study, I found that Aceh still struggles for good transparency as the province has not passed any qanun on the issue, leading its citizens to have a limited platform for questioning and critiquing government's policies. I found that MPs and executives alike perceived accountability to human beings as a purely administrative process of preparing financial statements, with the audit and presentation in a yearly parliamentary session on financial performance sufficiently discharging their responsibility. Such a narrow perspective of accountability is problematic, for the idea of stewardship in Islam conveys a message that those who have been entrusted with public resources should be responsible and accountable 
in their utilisation. The two dimensions of accountability in Islam embrace accountability as a concept of both internal and external motivations to deliver social justice.

In general, this study shows that the implementation of Islamic principles and values in Aceh's budgetary management remains unsatisfactory despite the enactment of Shari'a in the province. One reason for this may be because many still perceive Shari'a as applying only to ritual and criminal law. Thus, the executives and MPs tended to regard Islamic budgeting as allocating more funds to the 'Shari'a' agencies, rather than embedding Islamic values and principles into the budgeting process. Muslim scholars interviewed in this study regard this as a result of having Shari'a institutionalised, such that Shari'a's roles in other aspects of human activity have become understated. Hence, I suggest it is important for Aceh provincial government to view accountability from a more holistic perspective, understanding Shari'a beyond the context of ritual and criminal law so that it can be used as a guide to achieve good budgetary management, in order to deliver social justice.

Having summarised my key findings, I move next to outlining the study's contributions.

\subsection{Research Contributions}

As outlined in Chapter 1, this study's objectives study were to investigate poor budget cycles in Aceh's local government, its impacts on budget execution, and the influence of Islamic teaching in Aceh's budgetary management. Based on my findings and theoretical analysis to address these objectives, my study has provided contributions to the literature in several ways.

First, for the implementation of the SoW framework into government budgeting and accountability. B\&T (1999) suggest that when multiple orders of worth are involved in a discussion, oftentimes disputes occur, with participants exchanging criticisms and blame. These are then frequently resolved through compromise arrangements. However, my analysis highlights new viewpoints when I applied this framework to the budgeting process and accountability in the public sector. I argue that, while compromise arrangements in the budgeting process can and do resolve the conflicting interests of the actors, such arrangements may also possible to cause problems for accountability when conducted in a setting where government is less transparent, and no transparency law has been enacted. 
Second, in regards to orders of worth, my findings confirmed that, in the context of budgeting, the provincial government was classified into civic and domestic orders of worth, supporting the studies of B\&T (1999) and Le Maître (2006). More interestingly, when applied to the context of Aceh local government, the criteria of the industrial order appeared in the justifications of executives, despite being initially classified only in civic and domestic orders. The executives offered justifications on the importance of accounting and economic approaches in allocating financial resource to the government having an effective and efficient budget. Nevertheless, linking their arguments to the budgeting regulations in Indonesia, which embrace the implementation of performance-based budgeting, I consider that the presence of industrial order in Aceh government budgeting may also be linked to a hierarchy of trust, a characteristic of domestic order.

Most interestingly, however, the criteria of the world of inspiration also appeared in minority of interviewees' justifications in this study, regarding government activities (e.g. budgeting) as sacred in Islam, and therefore held accountable in the hereafter. This perspective gives a significant contribution to the application of SoW in the idea of accountability as no prior study has provided a linked between the inspired world and accountability. My findings indicate that when applied to a devout Muslim society, there is an extra thread of accountability, not present in non-Islamic societies, i.e. accountability to Allah in the hereafter. Thus, this study shows that classifying government officials/politicians only to one or two specific orders of worth may be difficult, or even inappropriate, as it is possible for subjects and objects to inhabit more than two orders of worth at once, depending on a country's governmental structure and society's belief. The justifications of the interviewees regarding budgeting also showed the budget is not merely perceived as an accounting tool but also as a symbol for due process and legality, a demonstration of moral reasoning, good manner and etiquette, and a religious activity in Islamic belief.

Third, I regard that this study contributes to the Islamic accounting literature by outlining the challenges of implementing Islamic principles and values into government budgeting. For example, Islamic principles and values may be difficult to implement into budgeting activities without taking a holistic approach. In this study, the 'mindset' toward 
Islamic budgeting as only concerning the allocation of funds to Shari'a agencies formed a major challenge to this implementation. Further, the presence of these Shari'a agencies have created a gap between so-called 'Islamic' agencies and 'non-Islamic' agencies. As a result, Shari'a becomes understated, as if it only regulates 'sacred' activities, such as worship activities, criminal law, and clothing, when the division between sacred and non-sacred activities was removed when Islam was revealed to the Prophet Muhammad (peace be upon him).

Other than theoretical contributions, my study also makes contributions to practice through noting some improvements that Aceh provincial government can make to achieve better budgetary management and accountability. These are: executives and DPRA addressing clearly the format of KUA-PPAS submission to avoid future miscommunication; passing a qanun on transparency; improving integration between government agencies in planning and budgeting process; providing a way to improve government accountability through allowing greater participation of the public in decision-making; and developing a clear blueprint of Shari'a implementation in Aceh covering a broader area, including government planning and budgeting activities.

Notwithstanding the contributions to the literature and practice outlined above, I recognise that this study also has limitations and so I turn to these next.

\subsection{Limitations of the Research}

This study employed qualitative and interpretive approaches, making it subjective in nature. As mentioned in Chapter 4, generalisability is not an aim of this study because, being located within an interpretivist research paradigm, I do not intend to provide conclusive answers to the investigated phenomenon (Adams et al., 2018). Although this would be regarded as unacceptable in positivist research paradigms, interpretivists instead consider it unavoidable, being concerned with the co-construction and interpretation of meanings between researcher and participant/s (Lietz et al., 2006). Questions of validity and reliability in interpretive research are addressed through the examination of trustworthiness (Lietz et al., 2006; Galdas, 2017), not statistical tests. Throughout this study, I have attempted to meet this criterion through a self-critical stance and data triangulation. Nevertheless, the reader will judge whether I have succeeded. 
Another limitation of this study is my decision to limit it to a single case study, Aceh province. As my findings show, Aceh's budgetary management problems are complex and not limited to budget delays. Hence, my findings should be treated with caution when applied to other research settings, especially those with different government structures, budgeting systems, and social dynamics. Nevertheless, this also delivers future research opportunities, as elaborated in the next section.

\subsection{Suggestions for Further Research}

The findings of this research suggest several future research opportunities in budgetary management. First, as this study investigated the impacts of budget delays only from the perspectives of government officials/politicians, scholars, and a corruption watchdog, further investigation on the perspectives of the public would deepen understandings of how late budget approval impacted citizen's welfare. Second, in Chapter 5, I outlined other problems in Aceh's budgetary management, including conflicting interests in AF scheme. MP participants argued that $\mathrm{AF}$ aims to allocate public aspirations within the local budget. However, the impacts of the programmes allocated through this scheme to the economy and social well-being remains unexplored. This topic may potentially be explored further. Lastly, corruption watchdog and scholar participants argued that AF has provided MPs with opportunities for corruption through bogus programmes, marking up budgets, and interfering in the procurement process. Executive participants commented that implemented online systems can address risks of interference. This indicates research opportunities on the quality of Aceh's monitoring and control systems for the implementation of AF programmes, given programmes proposed through this scheme are allocated and executed under different agencies' budgets and work plans.

\subsection{Autobiographical Reflection}

Conducting this study has been a thought-provoking journey and an invaluable learning experience for me. This study has taught me a lot, as I gained an understanding of the dynamics of research process in a qualitative study, an iterative process, which sometimes can be messy, tedious, and frustrating. However, at many times, I considered the journey of discovery to be an exciting and rewarding experience. 
This study helped me to understand the complexity of problems of budgetary management in a public sector setting. In the case of Aceh, considering all the justifications, criticisms, and recommendations expressed by participants of this study on late budget approval, I view as a key theme that Aceh's government needs to establish a budgeting process with less conflicting interest and more transparency, to improve the economic and social well-being of its citizens. It is therefore extremely important for governments to view accountability holistically to encourage responsible and accountable conduct among government officials and politicians. 


\section{REFERENCES}

1945 Constitution. (1945). Jakarta: Republic of Indonesia.

Abedifar, P., Ebrahim, S. M., Molyneux, P., \& Tarazi, A. (2015). Islamic Banking and Finance: Recent Empirical Literature and Directions for Future Research. Journal of Economic Surveys, 29(4), 637-670.

Abuznaid, S. (2006). Islam and Management: What Can Be Learned? Thunderbird International Business Review, 48(1), 125-139.

Adams, C., Hoque, Z., \& McNicholas, P. (2018). Case Studies and Action Research. In Z. Hoque (Ed.), Methodological Issues in Accounting Research (pp. 486-497). London: Spiramus Press.

Adnan, M. A., \& Bakar, N. B. A. (2009). Accounting Treatment for Corporate Zakat: A Critical Review. International Journal of Islamic and Middle Eastern Finance and Management, 2(1), 32-45.

Afifuddin, H. B., \& Siti-Nabiha, A. (2010). Towards Good Accountability: The Role of Accounting in Islamic Religious Organisations. World Academy of Science, Engineering and Technology, 66, 1133-1139.

Akbar, R. (2011). Performance Measurement and Accountability in Indonesian Local Government. (Doctoral), Curtin University, Australia.

Alford, J., \& O'Flynn, J. (2009). Making Sense of Public Value: Concepts, Critiques and Emergent Meanings. International Journal of Public Administration, 32(3-4), 171-191.

Almqvist, R., Grossi, G., van Helden, J., \& Reichard, C. (2013). Public Sector Governance and Accountability. Critical Perspectives on Accounting, 24(7-8), 479-487.

Amujiri, B. (2012). Budgeting at Local Government Level: Preparation, Problems and Prospects. Journal of Religion and Human Relations, 1(4), 57-70.

Andrews, T. (2012). What Is Social Constructionism. Grounded Theory Review, 11(1), 39-46.

Annisette, M., \& Richardson, A. J. (2011). Justification and Accounting: Applying Sociology of Worth to Accounting Research. Accounting, Auditing \& Accountability Journal 24(2), 229-249.

Aspinall, E., Hillman, B., McCawley, P., \& ANU Enterprise Pty Ltd Staff. (2012). Governance and Capacity Building in Post-Crisis Aceh. ANU: ANU Enterprise Pty Limited.

Badan Pusat Statistik. (2018). Statistik Indonesia 2018. [Statistical Yearbook of Indonesia 2018].

Retrieved 26/09/2018

from

https://www.bps.go.id/publication/2018/07/03/5a963c1ea9b0fed6497d0845/sta tistik-indonesia-2018.html 
Badan Pusat Statistik Aceh. (2010). Penduduk Menurut Wilayah Dan Agama Yang Dianut. [Aceh's Population Based on Religion]. Retrieved 10/09/2018 from https://sp2010.bps.go.id/index.php/site/tabel?tid=321\&wid=1100000000

Badan Pusat Statistik Aceh. (2018a). Aceh Dalam Angka, 2018 [Aceh Province in Figures, 2018]. Banda Aceh: Badan Pusat Statistik Aceh.

Badan Pusat Statistik Aceh. (2018b). Keadaan Ketenagakerjaan Februari 2018. [Employment, February 2018]. Retrieved 11/09/2018 from https://aceh.bps.go.id/pressrelease/2018/05/07/444/keadaan-ketenagakerjaanfebruari-2018

Badan Pusat Statistik Aceh. (2018c). Pertumbuhan Ekonomi Aceh Triwulan I - 2018. [Aceh Economic Growth, Quarter I - 2018]. Retrieved 11/09/2018 from https://aceh.bps.go.id/pressrelease/2018/05/07/441/pertumbuhan-ekonomiaceh-triwulan-i---2018.html

Badan Pusat Statistik Aceh. (2018d). Profil Kemiskinan Dan Tingkat Ketimpangan Pengeluaran Penduduk Provinsi Aceh Maret 2018. [Poverty and Consumption Inequality in Aceh, March 2018]. Retrieved 11/09/2018 from https://aceh.bps.go.id/pressrelease/2018/07/16/439/profil-kemiskinan-dantingkat-ketimpangan-pengeluaran-penduduk-provinsi-aceh-maret-2018.html

Basri, H., \& Nabiha, A. S. (2016). Accountability of Local Government: The Case of Aceh Province, Indonesia. Asia Pacific Journal of Accounting and Finance, 3(1), 1-14.

Batley, R., \& Larbi, G. (2004). The Changing Role of Government: The Reform of Public Services in Developing Countries. New York: Springer.

Baydoun, N., Sulaiman, M., Willet, R. J., \& Ibrahim, S. H. b. M. (2018). Principles of Islamic Accounting. Singapore: John Wiley \& Sons.

Bergsteiner, H. (2012). Accountability Theory Meets Accountability Practice. Bingley: Emerald Group Publishing.

Berry, A. J., \& Otley, D. T. (2004). Case Based Research in Accounting. In The Real Life Guide to Accounting Research: A Behind-the-Scenes View of Using Qualitative Research Method. Oxford: Elsevier Ltd.

Blöndal, J. R., Hawkesworth, I., \& Choi, H.-D. (2009). Budgeting in Indonesia. OECD Journal on Budgeting, 2, 1-31.

Boltanski, L., \& Thévenot, L. (1999). The Sociology of Critical Capacity. European Journal of Social Theory, 2(3), 359-377.

Boltanski, L., \& Thévenot, L. (2006). On Justification: Economies of Worth (C. Porter, Trans.). Paris: Princeton University Press.

Bovens, M. (2007). Analysing and Assessing Accountability: A Conceptual Framework. European Law Journal, 13(4), 447-468. 
BPKA Aceh Province. (2019). Date of Budget Approval for Aceh's Provincial Government. Banda Aceh: Financial and Property Management Agency (BPKA) Aceh Province.

Bräutigam, D. (2004). The People's Budget? Politics, Participation and Pro-Poor Policy. Development Policy Review, 22(6), 653-668.

Brunet, M., \& Aubry, M. (2016). The Three Dimensions of a Governance Framework for Major Public Projects. International Journal of Project Management, 34(8), 1596-1607.

Chua, W. F. (1986). Radical Developments in Accounting Thought. The Accounting Review, 61(4), 601-632.

Creswell, J. W., \& Poth, C. N. (2018). Qualitative Inquiry and Research Design: Choosing among Five Approaches (4th ed.). California: SAGE Publications.

Crotty, M. (1998). The Foundations of Social Research: Meaning and Perspective in the Research Process. London: Sage Publications.

Denhardt, J. V., \& Denhardt, R. B. (2015). The New Public Service: Serving, Not Steering. New York: Routledge.

Dixon, G., \& Hakim, D. (2015). Chapter 9 Making Indonesia's Budget Decentralization Work: The Challenge of Linking Planning and Budgeting at the Local Level. In The Many Faces of Public Management Reform in the Asia-Pacific Region (pp. 207-245).

Dormer, R. (2018). Accountability and Worth: A Study of New Zealand's Tertiary Education Institutions. Public Money Management, 38(2), 111-120.

DPRA. (2019). 2018 Budget Timeline. Banda Aceh: Aceh Local Parliament (DPRA).

Drazen, A., \& Eslava, M. (2006). Pork Barrel Cycles. Cambridge: National Bureau of Economic Research. Retrieved 12/04/2019 from https://www.nber.org/papers/w12190

Ebdon, C. (2002). Beyond the Public Hearing: Citizen Participation in the Local Government Budget Process. Journal of Public Budgeting, Accounting Financial Management, 14(2), 273-294.

Emirullah, C. (2013). The Budgetary Role of the Indonesian Parliament: The Impact of the Law on State Finances Paper presented at the KAPS's International Conference on Public Administration, Seoul, South Korea.

Farhan, Y. (2018). The Politics of Budgeting in Indonesia. (Doctoral), University of Sydney, Australia.

Flink, C. M. (2018). Budgetary Politics. In A. Farazmand (Ed.), Global Encyclopedia of Public Administration, Public Policy, and Governance. New York: Springer.

Galdas, P. (2017). Revisiting Bias in Qualitative Research: Reflections on Its Relationship with Funding and Impact. International Journal of Qualitative Methods, 16, 1-2. 
Gambling, T. E., \& Karim, R. A. A. (1986). Islam and 'Social Accounting'. Journal of Business Finance Accounting, 13(1), 39-50.

Gatra.com. (2018). Ekonomi Aceh Terpuruk Akibat Apba Telat Disahkan. [Aceh's economy is down due to late APBA approval]. Retrieved 29/10/2018 from https://www.gatra.com/rubrik/nasional/pemerintahan-daerah/321474-ekonomiAceh-terpuruk--akibat--APBA--telat-disahkan

GeRAK. (2017). Gerak Aceh Desak Gubernur Evaluasi Dana Aspirasi Dpra 2017. [Gerak Aceh Urges the Governor to Evaluate 2017 Dpra Aspiration Funds]. Retrieved 20/08/2018 from http://gerakaceh.id/gerak-aceh-desak-gubernur-evaluasi-dana-aspirasi-dpra2017/

Gioia, D. A., \& Pitre, E. (1990). Multiparadigm Perspectives on Theory Building. Academy of Management Review, 15(4), 584-602.

Goddard, A. (2004). Budgetary Practices and Accountability Habitus: A Grounded Theory. Accounting, Auditing \& Accountability Journal, 17(4), 543-577.

Grant, C., \& Osanloo, A. (2014). Understanding, Selecting, and Integrating a Theoretical Framework in Dissertation Research: Creating the Blueprint for Your "House". Administrative Issues Journal, 4(2), 4.

Gray, R., Adams, C., \& Owen, D. (2014). Accountability, Social Responsibility and Sustainability: Accounting for Society and the Environment. Harlow: Pearson Education Limited.

Grindle, M. (2012). Good Governance: The Inflation of an Idea. In Planning Ideas That Matter (pp. 259-282).

Guba, E. G., \& Lincoln, Y. S. (1994). Competing Paradigms in Qualitative Research. Handbook of Qualitative Research, 2(163-194), 105.

Hackbart, M. M., \& Ramsey, J. R. (1994). Budgeting Concepts and Processes: Perceived Value for State Budgeting. Journal of Public Budgeting, Accounting \& Financial Management, 6(1), 28-51.

Handoko, L. H., \& Kayadibi, S. (2013). The Implementation of Good Governance in the Era of Caliphate Omar Ibn Abd Al-Aziz (61h-101 H/717-720 M). Global Review of Islamic Economics and Business, 1(2), 133-149.

Haniffa, R., \& Hudaib, M. (2010). Islamic Finance: From Sacred Intentions to Secular Goals? Journal of Islamic Accounting and Business Research, 1(2), 85-91.

Herijanto, H. (2017). The Rahmatan Lil Alamin in Islamic Law and Economics. International Journal of Business Marketing and Management, 2(1), 21-27.

Hidayah, N. N., Lowe, A., \& Woods, M. (2019). Accounting and Pseudo Spirituality in Islamic Financial Institutions. Critical Perspectives on Accounting, 61, 22-37.

Hoepfl, M. C. (1997). Choosing Qualitative Research: A Primer for Technology Education Researchers. Journal of Technology Education, 9(1), 47-63. 
Hopwood, B., Mellor, M., \& O'Brien, G. (2005). Sustainable Development: Mapping Different Approaches. Sustainable Development Journal, 13(1), 38-52.

Hughes, O. E. (2012). Public Management and Administration. London: Palgrave Macmillan.

Islam, M. N. (2012). Understanding Good Governance in Islam: A Conceptual Analysis. International Journal of Islamic Thought, 1, 49-62.

Jordaan, J., \& Fourie, D. (2007). Contextualising the Measurement of Governance in Public Financial Management. Journal of Public Administration, 42(5), 35-45.

Jurnali, T., \& Siti-Nabiha, A. (2015). Performance Management System for Local Government: The Indonesian Experience. Global Business Review, 16(3), 351-363.

Kaidonis, M. A., \& Moerman, L. C. (2003). Indonesia's Public Sector Reforms and the Role of an Equalisation Formula: Legitimation, Authority or Obfuscation? Asian Review of Accounting, 11(2), 19-30.

Kamla, R. (2009). Critical Insights into Contemporary Islamic Accounting. Critical Perspectives on Accounting, 20(8), 921-932.

Kamla, R., \& Alsoufi, R. (2015). Critical Muslim Intellectuals' Discourse and the Issue of 'Interest' (Ribā): Implications for Islamic Accounting and Banking. Accounting Forum, $39(2), 140-154$.

Kamla, R., Gallhofer, S., \& Haslam, J. (2006). Islam, Nature and Accounting: Islamic Principles and the Notion of Accounting for the Environment. Accounting Forum, 30(3), 245-265.

Kelliher, F. (2011). Interpretivism and the Pursuit of Research Legitimisation: An Integrated Approach to Single Case Design. Leading Issues in Business Research Methods, 1(2), 123-131.

Kelly, G., Mulgan, G., \& Muers, S. (2002). Creating Public Value: An Analytical Framework for Public Service Reform. Strategy Unit, Cabinet Office. London: Strategy Unit, , Cabinet Office. $\quad$ Retrieved 15/09/2018 from https://www.sgb.gov.tr/IPA\%20Projesi/1.../5.../Creating\%20Public\%20Value.pdf

Kemp, R., Parto, S., \& Gibson, R. B. (2005). Governance for Sustainable Development: Moving from Theory to Practice. International Journal of Sustainable Development, 8(1-2), 1230.

Keping, Y. (2018). Governance and Good Governance: A New Framework for Political Analysis. Fudan Journal of the Humanities Social Sciences, 11(1), 1-8.

Khan, M. A. (2001). Public Finance in Islam. Islamic Studies, 40(2), 227-256.

Kimura, E. (2011). Indonesia in 2010: A Leading Democracy Disappoints on Reform. Asian Survey, 51(1), 186-195.

Kluvers, R. (2001). Program Budgeting and Accountability in Local Government. Australian Journal of Public Administration, 60(2), 35-43. 
Knodel, J. (1997). A Case for Nonanthropological Qualitative Methods for Demographers. Population Development Review, 23(4), 847-853.

Kontan.co.id. (2017). Sanksi Buat Daerah Tak Penuhi Mandatory Spending. [Sanctions for regions that do not meet mandatory spending]. Retrieved 27/09/2018 from https://nasional.kontan.co.id/news/sanksi-buat-daerah-tak-penuhi-mandatoryspending

Koppell, J. G. (2005). Pathologies of Accountability: ICANN and the Challenge of "Multiple Accountabilities Disorder". Public Administration Review, 65(1), 94-108.

Krefting, L. (1991). Rigor in Qualitative Research: The Assessment of Trustworthiness. The American Journal of Occupational Therapy, 45(3), 214-222.

Kristensen, J. K., Groszyk, W., \& Bühler, B. (2002). Outcome-Focused Management and Budgeting. OECD Journal on Budgeting, 1(4), 7-34.

Le Maître, D. (2006). La Construction Du Budget Des Communes Rurales. [The construction of the rural communes budget]. Revue Française de Gestion(9), 321-335.

Lewis, M. (2001). Islam and Accounting. Accounting Forum, 25(2), 103-127.

Lietz, C. A., Langer, C. L., \& Furman, R. (2006). Establishing Trustworthiness in Qualitative Research in Social Work: Implications from a Study Regarding Spirituality. Qualitative Social Work, 5(4), 441-458.

Mahomedy, C. A. (2013). Islamic Economics: Still in Search of an Identity. International Journal of Social Economics, 40(6), 556-578.

Maldonado, N. (2010). The World Bank's Evolving Concept of Good Governance and Its Impact on Human Rights. Paper presented at the Doctoral Workshop on Development and International Organizations, Stockholm, Sweden.

Maniagasi, H. A., Bharanti, E., \& Christian, F. (2017). Faktor-Faktor Yang Menyebabkan Keterlambatan Penyusunan Anggaran Pendapatan Dan Belanja Daerah (Apbd): Studi Pada Pemerintah Daerah Kabupaten Sarmi Tahun Anggaran 2010-2012. [Factors in Budget Delay (Case Study of Sarmi District for the Fiscal Year 2010-2012)]. Jurnal Kajian Ekonomi dan Keuangan Daerah, 1(2).

Mason, J. (2018). Qualitative Researching (3rd ed.). London: SAGE Publications Ltd.

Maxwell, J. A. (2012). Qualitative Research Design: An Interactive Approach (3rd ed.). California: SAGE Publications.

Memorandum of Understanding between the Government of the Republic of Indonesia and the Free Aceh Movement. (2005). Helsinki.

Merriam, S. B. (2009). Qualitative Research: A Guide to Design and Implementation. San Francisco: John Wiley \& Sons. 
Merriam, S. B., \& Tisdell, E. J. (2015). Qualitative Research: A Guide to Design and Implementation. San Francisco: John Wiley \& Sons.

Ministry of Finance. (2015). Kajian Dan Pembahasan Mengenai Dana Aspirasi Dewan Perwakilan Rakyat Republik Indonesia. [A Study and Discussion: Aspiration Fund for the House of Representatives of the Republic of Indonesia]. Jakarta: Ministry of Finance. Retrieved 5/4/2019

Ministry of Finance. (2017). Buku Pintar Dana Desa. [Village Fund: Handbook]. Jakarta: Ministry of Finance.

Moore, M. (1994). Public Value as the Focus of Strategy. Australian Journal of Public Administration, 53(3), 296-303.

Morgan, G. (1988). Accounting as Reality Construction: Towards a New Epistemology for Accounting Practice. Accounting, Organizations and Society, 13(5), 477-485.

Muda, I., \& Naibaho, R. (2018). Variables Influencing Allocation of Capital Expenditure in Indonesia. Paper presented at the IOP Conference Series: Earth and Environmental Science, 1-8.

Mulgan, R. (2000). 'Accountability': An Ever-Expanding Concept? Public Administration, 78(3), 555-573.

Murtuza, A. (2000). Hisba: The Islamic Variation for the Regulation of Marketplace and Commerce. Paper presented at the Sixth Interdisciplinary Perspective on Accounting Conference.

Napier, C. (2009). Defining Islamic Accounting: Current Issues, Past Roots. Accounting History, 14(1-2), 121-144.

Naqvi, I. H., Aziz, S., \& Zaidi, S. A. H. (2011). The Model of Good Governance in Islam. African Journal of Business Management, 5(27), 10984-10992.

Nawaz, T., \& Haniffa, R. (2017). Determinants of Financial Performance of Islamic Banks: An Intellectual Capital Perspective. Journal of Islamic Accounting Business Research, 8(2), 130-142.

Neale, P., Thapa, S., \& Boyce, C. (2006). Preparing a Case Study: A Guide for Designing and Conducting a Case Study for Evaluation Input. Massachusetts: Pathfinder international Massachusetts.

Noble, H., \& Smith, J. (2014). Bias in Research. Evidence-based nursing, 17(4), 100-101.

Noble, H., \& Smith, J. (2015). Issues of Validity and Reliability in Qualitative Research. Evidence-Based Nursing, 18(2), 34-35.

The Noble Qur'an (English Translation). Retrieved 25/09/2018 from https://quran.com/

Norton, A., \& Elson, D. (2002). What's Behind the Budget: Politics, Rights and Accountability in the Budget Process. London: Overseas Development Institute. 
Norum, K. E. (2008). Reality and Multiple Realities. In L. M. Given (Ed.), The Sage Encyclopedia of Qualitative Research Methods. California: SAGE Publications, Inc.

Noy, C. (2008). Sampling Knowledge: The Hermeneutics of Snowball Sampling in Qualitative Research. International Journal of Social Research Methodology, 11(4), 327-344.

O’Leary, R. (2015). From Silos to Networks. In M. E. Guy \& M. M. Rubin (Eds.), Public Administration Evolving: From Foundations to the Future. New York: Routledge.

OECD. (2015). Roles of the Centres of Government. In Government at a Glance 2015. Paris: OECD Publishing.

Owechi, J. H., \& Namara, R. B. (2012). Good Governance Practices and the Management of Public Funds in the Public Sector of Uganda. International Journal of Policy Studies, 3(2), 43-58.

Oxford University Press. (2018). Government. Oxford English Dictionary. Retrieved 3/09/2018 from https://en.oxforddictionaries.com/definition/government

Palinkas, L. A., Horwitz, S. M., Green, C. A., Wisdom, J. P., Duan, N., \& Hoagwood, K. (2015). Purposeful Sampling for Qualitative Data Collection and Analysis in Mixed Method Implementation Research. Administration Policy in Mental Health Services Research, 42(5), 533-544.

Parthasarathy, D. (2005). Taking Responsibilities and Participation Seriously: A Critique of 'Good Governance. In Christoph Eberhard, Droit, gouvernance et développement durable (pp. 307-321). Paris: Karthala Editions.

Pemerintah Aceh. (n.d.). Indeks Pemerintahan. [Government Index]. Retrieved 25/04/2019 from https://acehprov.go.id/pemerintahan.html

Peters, K. (2001). When Reform Comes into Play: Budgeting as Negotiations between Administrations. Accounting, Organizations and Society, 26(6), 521-539.

Possumah, B. T., \& Ismail, A. G. (2012). Baitul Mal and Legal Constraint: Public Wealth Management in Malaysian Context. International Journal of Academic Research in Business Social Sciences, 2(11), 27.

Pryor, F. L. (1985). The Islamic Economic System. Journal of Comparative Economics, 9(2), 197-223.

Republic of Indonesia. (2001a). Act No.18/2001 on Special Autonomy for Aceh Province. Republic of Indonesia.

Republic of Indonesia. (2001b). Act No.21/2001 on Special Autonomy for Papua Province. Republic of Indonesia.

Republic of Indonesia. (2003). Act No.17/2003 on State Finances. Republic of Indonesia.

Republic of Indonesia. (2004). Act No. 33/2004 on Fiscal Balance between Central Government and Local Governments. Republic of Indonesia. 
Republic of Indonesia. (2005). Act No. 58/2005 on Local Budget Management. Republic of Indonesia.

Republic of Indonesia. (2006). Act No.11/2006 on the Governing of Aceh. Republic of Indonesia.

Republic of Indonesia. (2014). Act No.6/2014 on Village. Republic of Indonesia.

Ritchie, J., Lewis, J., Lewis, P. S. P. J., Nicholls, C. M. N., \& Ormston, R. (2013). Qualitative Research Practice: A Guide for Social Science Students and Researchers. London: SAGE Publications.

Rizk, R. (2014). Islamic Environmental Ethics. Journal of Islamic Accounting and Business Research, 5(2), 194-204.

Romzek, B. S. (2000). Dynamics of Public Sector Accountability in an Era of Reform. International Review of Administrative Sciences, 66(1), 21-44.

Romzek, B. S., \& Dubnick, M. J. (1987). Accountability in the Public Sector: Lessons from the Challenger Tragedy. Public Administration Review, 47(3), 227-238.

Ross, M. L. (2005). Resources and Rebellion in Aceh, Indonesia. In Understanding Civil War (Vol. 2, pp. 35-58). Washington DC: The World Bank.

Rothstein, B. (2012). Good Governance. In D. Levi-Faur (Ed.), The Oxford Handbook of Governance. England: Oxford University Press.

Schedler, A., Diamond, L. J., \& Plattner, M. F. (1999). The Self-Restraining State: Power and Accountability in New Democracies. Colorado: Lynne Rienner Publishers.

Seidel, J. V. (1998). Qualitative Data Analysis. Retrieved 06/09/2018 from www.qualisresearch.com

Seifert, J., \& Li, H. (2015). Indonesia's Fiscal Decentralization and Its Effect on Provincial Public Finances. Public Finance Management, 15(2), 108.

Sekaran, U., \& Bougie, R. (2016). Research Methods for Business: A Skill Building Approach. West Sussex: John Wiley \& Sons.

Serambinews.com. (2018a). Irwan Djohan Bongkar Penyebab Terlambatnya Pengesahan Apba 2018, Ada Yang Sibuk Pada Rp 1,7 Triliun. [Irwan Djohan Dismantles the Causes of Late APBA 2018 Approval, They are Busy at Rp1.7 Trillion]. Serambi Indonesia. Retrieved 29/10/2018 from http://aceh.tribunnews.com/2018/01/13/irwandjohan-bongkar-penyebab-terlambatnya-pengesahan-apba-2018-ada-yang-sibukpada-rp-17-triliun

Serambinews.com. (2018b). Mendagri Sahkan Pergub Apba 2018. [Minister of Home Affairs Enacts the Governor Decree on 2018 Aceh's Budget]. Retrieved 23/08/2018 from http://aceh.tribunnews.com/2018/03/22/mendagri-sahkan-pergub-apba-2018 
Sinclair, A. (1995). The Chameleon of Accountability: Forms and Discourses. Accounting, Organizations and Society, 20(2), 219-237.

Sinkovics, R. R., \& Alfoldi, E. A. (2012). Progressive Focusing and Trustworthiness in Qualitative Research. Management International Review, 52(6), 817-845.

Sofyani, H., Akbar, R., \& Ferrer, R. C. (2018). 20 Years of Performance Measurement System (Pms) Implementation in Indonesian Local Governments: Why Is Their Performance Still Poor? Asian Journal of Business and Accounting, 11(1), 151-184.

Subechan, S., Hanafi, I., \& Haryono, B. S. (2014). Analisis Faktor-Faktor Penyebab Keterlambatan Penetapan Apbd Kabupaten Kudus. [Analysis of the Factors Behind Budget Delay in Kudus Regency]. WACANA Jurnal Sosial dan Humaniora, 17(1), 35-46.

Sutton, J., \& Austin, Z. (2015). Qualitative Research: Data Collection, Analysis, and Management. The Canadian Journal of Hospital Pharmacy, 68(3), 226-231.

Tahir, H. M. (1988). Islamic Budgetary Policy: In Theory and Practice. (Doctoral), University of Aberdeen.

Tempo.co. (2013). Pengesahan Anggaran Provinsi Aceh Selalu Terlambat. [Budget Approval in Aceh Province Is Always Late]. Retrieved 23/08/2018 from https://nasional.tempo.co/read/455707/pengesahan-anggaran-provinsi-acehselalu-terlambat

Thahar, M. (2016). Performance Measurement Evolution and Accountability in Indonesian Regional Governments. (Master), RMIT University, Australia.

Trokic, A. (2015). Islamic Accounting; History, Development and Prospects. European Journal of Islamic Finance, 2, 1-5.

Uhr, J. (1993). Redesigning Accountability: From Muddles to Maps. The Australian Quarterly, 65(2), 1-16.

UNESCAP. (2006). What Is Good Governance? Retrieved 20/10/2018 from https://www.unescap.org/resources/what-good-governance

Veiga, L. G., Kurian, M., \& Ardakanian, R. (2015). Public Budgets: Governance Structures, Norms, and Organizational Practices. In Intergovernmental Fiscal Relations: Questions of Accountability and Autonomy (pp. 25-46). Cham: Springer International Publishing.

Velayutham, S. (2014). "Conventional" Accounting Vs "Islamic" Accounting: The Debate Revisited. Journal of Islamic Accounting and Business Research, 5(2), 126-141.

Venning, P. (2009). Impact of Budget Support on Accountabilities at the Local Level in Indonesia. OECD Journal on Budgeting, 9(1), 1-29.

Wildavsky, A. B. (1997). The New Politics of the Budgetary Process. Boston: Addison Wesley Publishing Company. 
World Bank. (2006). Aceh Public Expenditure Analysis : Spending for Reconstruction and Poverty Reduction. In Public Expenditure Review. Washington, DC: World Bank.

World Bank. (2007). Public Financial Management in Aceh: Measuring Financial Management Performance in Aceh's Local Governments. Retrieved 5/09/2018 from https://openknowledge.worldbank.org/handle/10986/7885

World Bank. (n.d.). What Are the Main Dimensions of Governance? Retrieved 25/10/2018 from http://web.worldbank.org/archive/website01020/WEB/0_CON-7.HTM

Yin, R. K. (2016). Qualitative Research from Start to Finish. New York: The Guilford Press.

Zaman, A. (2010). Islamic Economics: A Survey of the Literature. Islamic Studies, 49(1), 3763. 


\section{APPENDIX A List of Arabic and Islamic Words Used}

Al-hisba

Al-kateeb

Allah

Amanah

Aslama

Daruriyyat

Fathanah

Hadith

Hajiyyat

Hajj

Khalifah

Khalwat

Maslahah of the Ummah

Qur'an

Qanun

Riba

Salam

Salat

Shari'a

Siddiq

Tabligh

Tahsiniyyat

Zakat

Zina
Islamic institution in the seventh century, aiming to protect Islamic society from fraud and exploitation

Accountant

God

Trustworthy

Complete submission to Allah

Essential/important

Intelligent

Teachings of the Prophet Muhammad (sayings and actions)

Complementary

Pilgrimage

Stewards of Allah

Illicit contact with the opposite sex

Public interest

Islamic Holy Book

A term for regional regulation used in Aceh province

Usury and other forms of activities which enrich individual(s) by exploiting others

Peace

Daily prayers

Islamic law

Truthful

Transparent

Desirables

Alms

Premarital sex 


\section{APPENDIX B Linkage between Research Questions and Interview Questions}

\begin{tabular}{|c|c|}
\hline Research Questions & Interview Questions \\
\hline $\begin{array}{l}\text { RQ1: What are the reasons } \\
\text { behind the late budget approval } \\
\text { in Aceh? }\end{array}$ & $\begin{array}{l}\text { Scholars (Economics and Accounting) } \\
\text { 1. What do you think of Aceh's budget cycle? } \\
\text { 2. In your opinion, what is/are the main problem(s) that Aceh's local budget was always approved late? } \\
\text { 3. In your opinion, if the budget cycle is well-managed, do you think the Aceh's government will perform } \\
\text { better in managing the budget? } \\
\text { 4. In your opinion, other than late approval, what are the problems in Aceh's budgetary management? } \\
\text { 5. Regarding the resource allocation and budget management done by Aceh government, do you think } \\
\text { that they have done a good job so far? } \\
\text { 6. What are the main aspects that should be considered in resource allocation, in the case of Aceh? } \\
\text { 7. If we see the budget, allocation for consumptive spending is higher than productive spending, what } \\
\text { do you think about this? } \\
\text { 8. Since MoU Helsinki and UUPA were signed, Aceh receives unprecedented amount of fund from } \\
\text { central government. In your opinion, how Aceh government should allocate these resources? } \\
\text { 9. How do you see budget execution in terms of government programs? Does the late approval of } \\
\text { 10. Whatget influence positively or negatively on the execution of program? } \\
\text { 11. What comment about budget utilisation in Aceh? (data shows most of disbursement } \\
\text { 12. What should the legislature and executives do to overcome the problems in budgetary management? } \\
\text { Member of Local Parliament (Legislative) } \\
\text { 1. What do you think of Aceh's budget cycle? } \\
\text { 2. What do you think about its timeline? } \\
\text { 3. According to the data, since } 2006 \text { until now, the local budget was always approved late. Why did this } \\
\text { 4. Wappen? } \\
\text { 5. Is there particular sector that the parliament want the government to focus on? } \\
\text { 6. Regarding the resource allocation and budget management done by the government, do you think } \\
\text { 7hat they have done a good job so far? } \\
\text { 8. If we see the budget, allocation for consumptive spending is higher than productive spending, what } \\
\text { do you think about this? }\end{array}$ \\
\hline
\end{tabular}


9. How does the DPRA (Aceh's Parliament) see the accountability and transparency of Aceh local government in managing public fund?

10. What should they do to improve the accountability and transparency?

11. What should the legislative and executive do to overcome the problem of late approval of budget in the future?

\section{Executive Government}

1. What do you think of Aceh's budget cycle?

2. What do you think about its timeline?

3. According to the data, since 2009 until now, the local budget was always approved late. Why did this happen?

4. What were the reasons of local parliament disagreed to the proposed budget?

5. What do you think of those reasons?

6. What are the problems faced by the government when the budget is approved late?

7. Then, how the government overcome these problems?

8. If the budget were not approved late, do you think that Aceh's budget would not be in surplus by the end of the fiscal year?

9. Since MoU Helsinki and UUPA were signed, Aceh has received greater funding from central government. How has Aceh's government allocated these resources?

10. What are the considerations of the government and budget team when preparing the budget?

11. If we see the budget, allocation for consumptive spending is higher than productive spending, why would this happen?

12. In your opinion, what should the legislative and executive do to overcome the problem of late approval of budget in the future?

- Islamic Shari'a Agency

1. What is the role of Islamic Shari'a Agency in Aceh?

2. Does it have any influence on how the local budget is prepared?

\section{Non-Governmental Government (NGO)}

1. What do you think of Aceh's budget cycle?

2. What do you think about its timeline?

3. In your opinion, what is/are the main problem(s) that Aceh's local budget was always approved late?

4. What do you think of the reasons given by the government and parliament on this issue?

5. Do you think that this problem has anything to do with the quality and qualifications of those who prepared the budget? 


\begin{tabular}{|c|c|}
\hline & $\begin{array}{l}\text { 6. If the budget cycle is well-managed, do you think the government will perform well in managing the } \\
\text { budget? } \\
\text { 7. If the budget were not approved late, do you think that Aceh's budget would not be in surplus? } \\
\text { 8. In your opinion, other than late approval, what are the problems in Aceh's budgetary management? } \\
\text { 9. Regarding the resource allocation and budget management done by the government, do you think } \\
\text { that they have done a good job so far? If yes/no, why? } \\
\text { 10. What should the legislative and executive do to overcome the problems in budgetary management? }\end{array}$ \\
\hline $\begin{array}{l}\text { RQ2: What are the } \\
\text { consequences, if any, of late } \\
\text { budget approval in Aceh? }\end{array}$ & $\begin{array}{l}\text { Scholars (Economics and Accounting) } \\
\text { 1. What is/are the consequence(s) of the late approval of budget? } \\
\text { 2. What is/are the consequence(s) toward budgetary management/budget execution? } \\
\text { 3. How does this issue affect Aceh's economic and social well-being? } \\
\text { 4. Who will suffer great loss if this problem continues? How so? } \\
\text { 5. Do you think that the late approval of budget is the reason that Aceh's poverty rate and economic } \\
\text { growth are still poor? } \\
\text { Member of Local Parliament (Legislative) } \\
\text { 1. What are the consequences of the late approvals of budgets? } \\
\text { 2. Do all members of parliament realise these consequences of late approvals of budgets? } \\
\text { 3. If they knew, why do delays keep happening? } \\
\text { Executive Government } \\
\text { 1. Is the late approval of budgets are the reason that Aceh's poverty rate and economic growth are still } \\
\text { poor? } \\
\text { 2. If the budget were not approved late, do you think that Aceh's development would be better than } \\
\text { today? } \\
\text { Non-Governmental Government (NGO) } \\
\text { 1. How does this late budget approval affect Aceh's economy and social-being? } \\
\text { 2. Who will suffer great loss if the problem of late budget approval continues? How so? } \\
\text { 3. Then, do you think that the late approval of budget is one of the reason that Aceh's poverty rate and } \\
\text { economic growth are still poor? }\end{array}$ \\
\hline
\end{tabular}


RQ3: Does the budgetary management in Aceh local government represent a good implementation of Islamic principles and values?

a. If yes, how so?

b. If not, why not?

\section{Scholars (Islamic Studies)}

1. How does Islam actually view "public fund" and "budgeting"?

2. What do you think of Aceh's budgetary management, especially its budget cycle?

3. For the case of late approval of the local budget in Aceh, how does Islam see this issue?

4. How does Islam see politics in public budgeting? Is it allowed?

5. According to the data, the government of Aceh every year allocates the money more into consumptive activities or bureaucracy rather than productive activities, if we talk about Islamic point of view, how does Islam see this issue?

6. Do you think that the government of Aceh has managed the budget/public fund in accordance to the Shari'a? If yes/no, how so?

7. In your opinion, if Aceh's government and parliament carefully take the Islamic values and principles into account in the budgetary management, would this positively impact their work as well as society's well-being? How so?

8. Would this be one of the solutions to the poverty and economy problems in Aceh?

9. Does Aceh regulate anything about allocating resources through Qanun?

10. Why the implementation of Shari'a in Aceh is yet to engage in politics and governing?

11. Is it important for the Dinas Syari'at Islam to step up to encourage parliament to formulate Islamic public budgeting for Aceh?

12. What do you think about the accountability of the government of Aceh so far?

13. What should the government do to achieve good accountability in Islamic perspective?

14. In your opinion, what should the legislature and executives do to overcome the problems in budgetary management? Especially, in applying Islamic values to Aceh's budgetary management.

\section{Member of Local Parliament (Legislative)}

1. As we know, Aceh has applied Shari'a Law. Although the law does not rule the budgeting process, Islamic values strongly influences the activities of Aceh's society and government. Do you think that the Islamic principles and Islamic values have influenced the government and budget team in preparing the budget? If yes, how?

2. Another point in Islam is about inter-generational concern in public expenditure, meaning that the expenditure decision should be made by realising that it is important for future generations should be benefited from the expenditure. Do you think Aceh's budget has carried out this principle? If yes/no, why? 


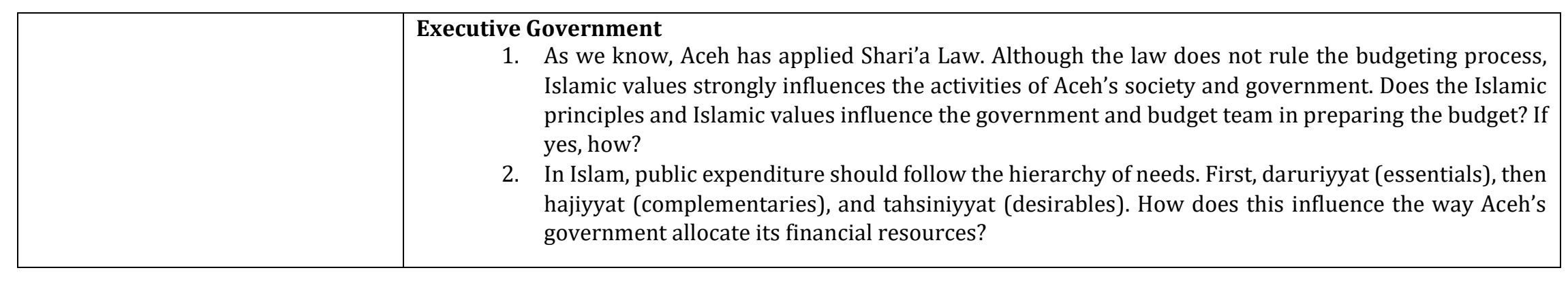




\section{APPENDIX C List of People Interviewed}

\begin{tabular}{|c|c|c|c|c|}
\hline No & Interviewee & Affiliation & Time of Interview & Type of Interview \\
\hline 1 & S01 & $\begin{array}{c}\text { Scholar } \\
\text { (Accounting/Economics) }\end{array}$ & $11 / 12 / 2018,15: 00$ & Semi-structured \\
\hline 2 & S02 & $\begin{array}{c}\text { Scholar } \\
\text { (Accounting/Economics) }\end{array}$ & $18 / 12 / 2018,11: 00$ & Unstructured \\
\hline 3 & S03 & $\begin{array}{c}\text { Scholar } \\
\text { (Accounting/Economics) }\end{array}$ & $07 / 01 / 2019,15: 00$ & Semi-structured \\
\hline 4 & SE04 & $\begin{array}{c}\text { Scholar } \\
\text { (Accounting/Economics) } \\
\text {; Government Advisor }\end{array}$ & $17 / 01 / 2019,15: 30$ & Semi-structured \\
\hline 5 & MS01 & Scholar (Islamic Studies) & $19 / 12 / 2018,17: 00$ & Semi-structured \\
\hline 6 & MS02 & Scholar (Islamic Studies) & $31 / 12 / 2018,09: 30$ & Semi-structured \\
\hline 7 & MSE03 & $\begin{array}{l}\text { Scholar (Islamic Studies); } \\
\text { Government Advisor }\end{array}$ & $03 / 01 / 2019,12: 00$ & Semi-structured \\
\hline 8 & MS04 & Scholar (Islamic Studies) & $03 / 01 / 2019,17: 30$ & Semi-structured \\
\hline 9 & MSE05 & $\begin{array}{l}\text { Scholar (Islamic Studies); } \\
\text { Islamic Shari'a Agency }\end{array}$ & $25 / 01 / 2019,17: 30$ & Semi-structured \\
\hline 10 & NGO01 & Corruption Watchdog & 04/01/2019, 10:00 & Semi-structured \\
\hline 11 & EXE01 & Internal Auditor & 07/01/2019, 09:00 & Semi-structured \\
\hline 12 & EXE02 & $\begin{array}{l}\text { Aceh Financial Agency } \\
\text { (BPKA) }\end{array}$ & $\begin{array}{c}\text { 07/01/2S019, } \\
17: 30\end{array}$ & Semi-structured \\
\hline 13 & EXE03 & BAPPEDA Aceh & $17 / 01 / 2019,10: 00$ & Semi-structured \\
\hline 14 & EXE04 & Former Internal Auditor & 01/02/2019, 09:00 & Semi-structured \\
\hline 15 & EXE05 & Islamic Shari'a Agency & $10 / 02 / 2019,21: 00$ & Unstructured \\
\hline 16 & LG01 & DPRA & $17 / 12 / 2018,12: 00$ & Semi-structured \\
\hline 17 & LG02 & DPRA & $31 / 12 / 2018,12: 00$ & Semi-structured \\
\hline 18 & LG03 & DPRA & 09/01/2019, 21:30 & Unstructured \\
\hline 19 & LG04 & DPRA & 09/02/2019, 17:30 & Semi-structured \\
\hline
\end{tabular}




\section{APPENDIX D List of NVivo Nodes and Major Themes Generated}

\section{NVivo Nodes}

\begin{tabular}{|c|c|c|c|}
\hline \multirow{2}{*}{ No. } & \multirow{2}{*}{ Parent Nodes } & \multicolumn{2}{|l|}{ Sub-nodes } \\
\hline & & Label & Technique \\
\hline \multirow{2}{*}{1.} & \multirow{2}{*}{$\begin{array}{l}\text { Lateness of } \\
\text { Budget Approval } \\
\text { in Aceh }\end{array}$} & $\begin{array}{l}\text { - } \text { Aspiration fund } \\
\text { - Conflict of interests } \\
\text { - Communication and } \\
\text { commitments }\end{array}$ & Top-down approach \\
\hline & & $\begin{array}{l}\text { - } 2018 \text { Governor decree } \\
\text { - Political interaction } \\
\text { - Clashes of authority }\end{array}$ & Bottom-up approach \\
\hline 2. & $\begin{array}{l}\text { Consequences of } \\
\text { lateness budget } \\
\text { approval }\end{array}$ & $\begin{array}{ll}\text { - } & \text { Budget Absorption } \\
\text { - } & \text { Economic Growth } \\
\text { - } & \text { Poverty }\end{array}$ & Top-down approach \\
\hline \multirow{2}{*}{3.} & \multirow{2}{*}{$\begin{array}{l}\text { The } \\
\text { Implementation } \\
\text { of Islamic } \\
\text { Teaching in } \\
\text { Budgetary } \\
\text { Management in } \\
\text { Aceh }\end{array}$} & $\begin{array}{l}\text { - Accountability in Islam } \\
\text { - Budgeting in Islam } \\
\text { - Challenges in the Implementation } \\
\text { of Islamic Budgeting }\end{array}$ & Top-down approach \\
\hline & & $\begin{array}{l}\text { - Accountability } \\
\text { - Leadership } \\
\text { - Politics } \\
\text { - Transparency }\end{array}$ & Bottom-up approach \\
\hline 4. & $\begin{array}{l}\text { Other Problems of } \\
\text { Budgetary } \\
\text { Management in } \\
\text { Aceh }\end{array}$ & $\begin{array}{ll}\text { - } & \text { Accountability } \\
\text { - } & \text { Budget Cycle } \\
\text { - } & \text { Corruption } \\
\text { - } & \text { Lack of database } \\
\text { - } & \text { Level of Education } \\
\text { - } & \text { Resource allocation } \\
\text { - } & \text { Transparency } \\
\end{array}$ & Bottom-up approach \\
\hline
\end{tabular}




\section{Major Themes Generated}

\begin{tabular}{|c|l|}
\hline No. & \multicolumn{1}{|c|}{ Themes } \\
\hline 1. & Political interaction between the executives and DPRA \\
\hline 2. & Aspiration fund \\
\hline 3. & Consequences of late budget approval: a domino effect \\
\hline 4. & $\begin{array}{l}\text { Islamic teachings in Aceh's budgetary management: issues in implementation } \\
\text { and the challenges }\end{array}$ \\
\hline
\end{tabular}




\section{APPENDIX E Participants' Information Sheet and Consent Form}

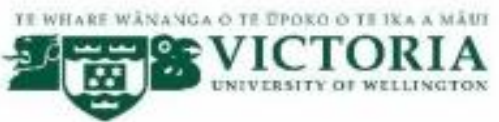

\section{Assessing Budgetary Management of Local Government in Aceh, Indonesia}

\section{INFORMATION SHEET FOR PARTICIPANTS}

You are invited to take part in this research. Please read this information before deciding whether or not to take part. If you decide to participate, thank you. If you decide not to participate, thank you for considering this request.

\section{Who am I?}

My name is Intan Farhana and I am a Masters student in Master of Commerce at Victoria University of Wellington. This research project is work towards my thesis.

\section{What is the aim of the project?}

This project aims to investigate the reasons behind the late adoption of Aceh's local budget in the last ten years. As $98 \%$ of Aceh's population are Muslims, I also would like to see how Islam views the public budgeting process and whether Islamic values influence the Aceh local government in preparing and managing the local budget.

This research has been approved by the Victoria University of Wellington Human Ethics Committee with the reference application number: 26553

\section{How can you help?}

You have been invited to participate because your position in the government, parliament, university, or other non-profit organisations is considered relevant to answer my research questions. If you agree to take part, we can discuss the specific time and place that suit you for an interview. I will ask you some questions regarding budgetary management in Aceh. The interview will take around 60-90 minutes. I will audio record the interview with your permission and write it up later. You can choose to not answer any question or stop the interview at any time, without giving a reason. You can withdraw from the study by contacting me at any time within ten days after the interview, which is due on returned to you. If you withdraw, the information you provided will be destroyed or

\section{What will happen to the information you give?}

This research is confidential: This means that the researchers named below will be aware of your identity but the research data will be combined and your personal identity will not be revealed in any reports, presentations, or public documentation. However, your

- Confidentiality will be preserved except where you disclose something that causes me to be concerned about a risk of harm to yourself and/or others. 
role/position might be identified or inferred from the research outputs produced by this research.

Only my supervisors and I will read the notes or transcript of the interview. The interview transcripts, summaries and any recordings will be kept securely and destroyed on 20 July 2024.

\section{What will the project produce?}

The information from my research will be used in my Master research project and academic publications and conferences.

\section{If you accept this invitation, what are your rights as a research participant?}

You do not have to accept this invitation if you don't want to. If you do decide to participate, you have the right to:

- choose not to answer any question;

- ask for the recorder to be turned off at any time during the interview;

- withdraw from the study within ten days after the interview;

- ask any questions about the study at any time;

- receive a written summary of the interview;

- be able to read any reports of this research by emailing the researcher to request a copy.

If you have any questions or problems, who can you contact?

If you have any questions, either now or in the future, please feel free to contact me or my supervisor

\section{Student:}

Name: Intan Farhana

Email address: farhaninta@myvuw.ac.id

\section{Supervisor:}

Name: Dr Clare Markham

Role: Supervisor, Lecturer

School: School of Accounting and

Commercial Law

Phone: +644636960

clare.markham@vuw.ac.nz

\section{Human Ethics Committee information}

If you have any concerns about the ethical conduct of the research you may contact the Victoria University HEC Convenor: Dr Judith Loveridge. Email hec@vuw.ac.nz or telephone +64-4-463 6028 . 


\section{Assessing Budgetary Management of Local Government in Aceh, Indonesia}

\section{CONSENT TO INTERVIEW}

This consent form will be held for five years.

Researcher: Intan Farhana, School of Accounting and Commercial Law, Victoria University of Wellington.

- 1 have read the Information Sheet and the project has been explained to me. My questions have been answered to my satisfaction. I understand that I can ask further questions at any time.

- I agree to take part in an audio recorded interview.

I understand that:

- I may withdraw from this study at any point within ten days after my interview, which is due on $\_$and any information that $I$ have provided will be returned to me or destroyed.

- The identifiable information 1 have provided will be destroyed on 20 July 2024.

- Any information I provide will be kept confidential to the researcher and her supervisor.

- I am aware that my role/position may be identified or inferred from the research outputs.

- I understand that the results will be used for a Master research project and/or academic publications and/or presented to conferences.

- My name will not be used in reports, nor will any information that Yes $\square$ No $\square$ would personally identify me.

- I would like a summary of my interview

Yes $\square \quad$ No $\square$

- I would like to receive a copy of the final report

Yes $\square \quad$ No $\square$

- I would like to receive the summary and report documents by e-mail

Yes $\square \quad$ No $\square$

- I would like to receive the summary and report documents by mail Yes $\square$ No $\square$

Signature of participant:

Name of participant:

Date:

Contact details: 